\title{
Immersion Studies on Candidate Container Alloys for the Tuff Repository
}

Manuscript Completed: April 1991

Date Published: May 1991

\section{Prepared by}

J. A. Beavers, C. L. Durr

Cortest Columbus Technologies

2704 Sawbury Blvd.

Columbus, $\mathrm{OH} 43235$

\section{Prepared for}

Division of Engineering

Office of Nuclear Regulatory Research

U.S. Nuclear Regulatory Commission

Washington, DC 20555

NRC FIN D1692 


\section{DISCLAIMER}

This report was prepared as an account of work sponsored by an agency of the United States Government. Neither the United States Government nor any agency thereof, nor any of their employees, make any warranty, express or implied, or assumes any legal liability or responsibility for the accuracy, completeness, or usefulness of any information, apparatus, product, or process disclosed, or represents that its use would not infringe privately owned rights. Reference herein to any specific commercial product, process, or service by trade name, trademark, manufacturer, or otherwise does not necessarily constitute or imply its endorsement, recommendation, or favoring by the United States Government or any agency thereof. The views and opinions of authors expressed herein do not necessarily state or reflect those of the United States Government or any agency thereof. 


\section{DISCLAIMER}

Portions of this document may be illegible in electronic image products. Images are produced from the best available original document. 


\section{ABSTRACT}

Cortest Columbus Technologies (CC Technologies) is investigating the long-term performance of container materials used for high-level radioactive waste packages. This information is being developed for the Nuclear Regulatory Commission to aid in their assessment of the Department of Energy's application to construct a geologic repository for disposal of high-level radioactive waste. This report summarizes the results of exposure studies performed on two copper-base and two $\mathrm{Fe}-\mathrm{Cr}$-Ni alloys in simulated Tuff Repository conditions. Testing was performed at $90^{\circ} \mathrm{C}$ in three environments; simulated $\mathrm{J}-13$ well water, and two environments that simulated the chemical effects resulting from boiling and irradiation of the groundwater. Creviced specimens and U-bends were exposed to liquid, to vapor above the condensed phase, and to alternate immersion. A rod specimen was used to monitor corrosion at the vapor-liquid interface. The specimens were evaluated by electrochemical, gravimetric, and metallographic techniques following approximately 2000 hours of exposure.

Results of the exposure tests indicated that all four alloys exhibited acceptable general corrosion rates in simulated $\mathrm{J}-13$ well water. These rates decreased with time. Incipient pitting was observed under deposits on Alloy 825 and pitting was observed on both Alloy CDA 102 and Alloy CDA 715 in the simulated $J-13$ well water. No SCC was observed in U-bend specimens of any of the alloys in simulated $\mathrm{J}-13$ well water.

General corrosion rates of the copper-base alloys in an active-corrosion environment were moderate, and no SCC was observed. However, severe pitting and crevice corrosion occurred in this environment. Both Alloy $304 \mathrm{~L}$ and Alloy 825 exhibited low general corrosion rates with no evidence of localized corrosion (pitting, crevice corrosion or SCC) in a pitting environment in the absence of hydrogen peroxide $\left(\mathrm{H}_{2} \mathrm{O}_{2}\right)$, a species added to simulate the effects of radiolysis. Alloy 825 continued to exhibit good corrosion performance after $\mathrm{H}_{2} \mathrm{O}_{2}$ was added to the pitting environment; whereas, Alloy $304 \mathrm{~L}$ exhibited both pitting and $\mathrm{SCC}$ as a result of the $\mathrm{H}_{2} \mathrm{O}_{2}$ addition.

$$
\text { iii/iv }
$$




\section{TABLE OF CONTENTS}

$\underline{\text { Page }}$

EXECUTIVE SUMMARY $\ldots \ldots \ldots \ldots \ldots \ldots \ldots \ldots \ldots \ldots \ldots \ldots \ldots \ldots$

1. Introduction $\ldots \ldots \ldots \ldots \ldots \ldots \ldots \ldots \ldots \ldots \ldots \ldots \ldots \ldots \ldots \ldots \ldots \ldots \ldots$

2. Background - The Tuff Repository Environment $\ldots \ldots \ldots \ldots \ldots \ldots \ldots \ldots$

$2.1 \quad$ Nominal Environment $\ldots \ldots \ldots \ldots \ldots \ldots \ldots \ldots \ldots \ldots \ldots \ldots$

2.1.1 Thermal Effects .......................... 8

2.1.2 Radiation Effects $\ldots \ldots \ldots \ldots \ldots \ldots \ldots \ldots \ldots \ldots \ldots \ldots, 13$

2.2 Simulated Environments $\ldots \ldots \ldots \ldots \ldots \ldots \ldots \ldots \ldots \ldots \ldots \ldots$

2.2.1 Simulated J-13 Water ........................... 14

2.2.2 Selected Task 3 Environments ...................... 18

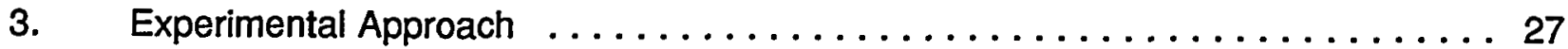

4. Corrosion Behavior In Simulated J-13 Water $\ldots \ldots \ldots \ldots \ldots \ldots \ldots \ldots \ldots$

$4.1 \quad$ Fe-Cr-Ni Alloys $\ldots \ldots \ldots \ldots \ldots \ldots \ldots \ldots \ldots \ldots \ldots \ldots \ldots \ldots \ldots \ldots \ldots \ldots$

4.1.1 General Corrosion ......................... 33

4.1.2 Localized Corrosion ........................... 40

4.1.3 Stress-Corrosion Cracking . .................. 41

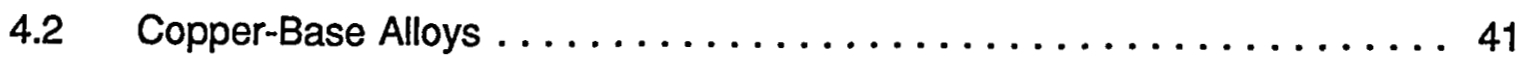

4.2.1 General Corrosion .......................... 41

4.2.2 Localized Corrosion ........................ 48

4.2.3 Stress-Corrosion Cracking $\ldots \ldots \ldots \ldots \ldots \ldots \ldots \ldots \ldots \ldots$

5. Corrosion Behavior In An Active Pitting Environment $\ldots \ldots \ldots \ldots \ldots \ldots$

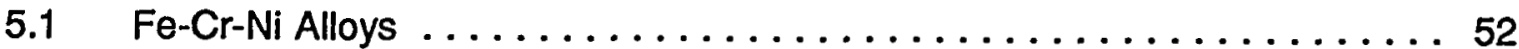

5.1 .1 General Corrosion ......................... 52

5.1 .2 Localized Corrosion ....................... 52

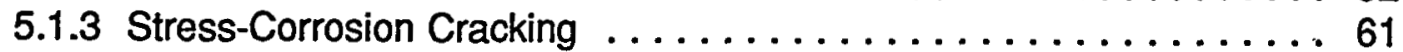

6. Corrosion Behavior In An Active Corrosion Environment .............6 68

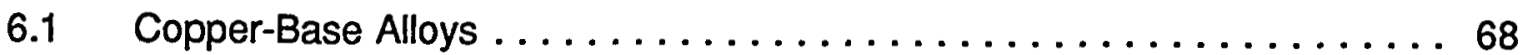

6.1 .1 General Corrosion ....................... 68

6.1 .2 Localized Corrosion ..........................68 68

6.1.3 Stress-Corrosion Cracking $\ldots \ldots \ldots \ldots \ldots \ldots \ldots \ldots \ldots \ldots \ldots$ 
Page

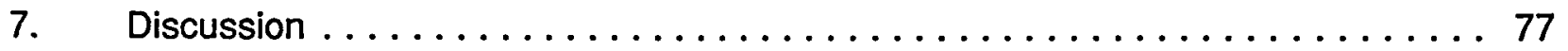

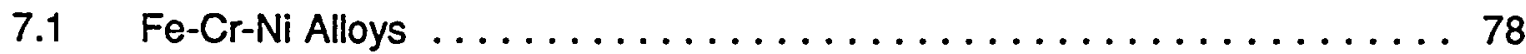

7.2 Copper-Base Alloys $\ldots \ldots \ldots \ldots \ldots \ldots \ldots \ldots \ldots \ldots \ldots \ldots$

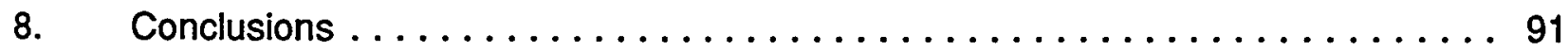

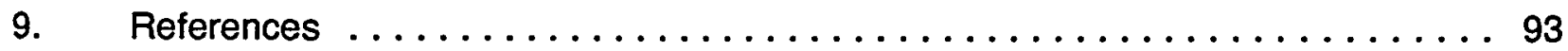

Appendix A: Potentiodynamic Polarization Technique $\ldots \ldots \ldots \ldots \ldots . \ldots 97$

Appendix B: Environmental Test Matrix .................. 101

Appendix C: Candidate Alloy Compositions $\ldots \ldots \ldots \ldots \ldots \ldots \ldots \ldots \ldots$ 


\section{LIST OF FIGURES}

Page

Figure 2.1 Representative Stratigraphic Section In Nevada Tuff (Drillhole UE25 a-1) (McCright-1984) . . . . . . . . . . . . . . . . . . . . 6

Figure 2.2 Comparative Canister Surface Temperature-Time Profiles For Different Waste Packages in A Tuff Repository (Vertical Emplacement, $50 \mathrm{~kW} /$ acre Areal Loading) (McCright-1984) . . . . . . . . . 9

Figure 2.3 Silicon And Sodium Concentrations In J-13 Well Water Reacted With Crushed G-1 Material At $150^{\circ} \mathrm{C}$ As A Function Of Time In Days (Knauss-1985a) . . . . . . . . . . . . . . . . . . 10

Figure 2.4 Aluminum, Potassium, Calcium, Magnesium, And pH Analyses From J-13 Well Water Reacted With Crushed G-1 Material At $150^{\circ} \mathrm{C}$ As A Function of Time In Days (Knauss-1985a)

Figure 2.5 CPP Curve For Alloy CDA 102 In Actual J-13 Well Water At $80^{\circ} \mathrm{C}$ (Scan Rate: $1 \mathrm{mV} / \mathrm{s}$ ) Produced By McCright (McCright1985)

Figure 2.6 Polarization Curve For Alloy CDA 102 In Simulated J-13 Well Water At $80^{\circ} \mathrm{C}$ Following A One Hour Initial Exposure (Beavers1988)

Figure 2.7 Polarization Curve For Alloy CDA 102 In Actual J-13 Well Water At $80^{\circ} \mathrm{C}$ Following $A$ Onè Hour Initial Exposure (Beavers1988)

Figure 2.8 Polarization Curve For Alloy CDA 102 In Simulated J-13 Well Water At $80^{\circ} \mathrm{C}$ Following A Fifteen Hour Initial Exposure (Beavers-1988)

Figure 2.9 Polarization Curve For Alloy CDA 102 in Actual J-13 Well Water At $80^{\circ} \mathrm{C}$ Following A Fifteen Hour Initial Exposure (Beavers1988)

Figure 2.10 Polarization Curve For Alloy CDA 102 In Simulated J-13 Well Water At $90^{\circ} \mathrm{C}$ Run At A Scan Rate of $0.6 \mathrm{~V} / \mathrm{hr}$ (Beavers1988)

Figure 2.11 Polarization Curve For Alloy CDA 715 In Simulated J-13 Well Water At $90^{\circ} \mathrm{C}$ Run At A Scan Rate of $0.6 \mathrm{~V} / \mathrm{hr}$ (Beavers1988) 


\section{LIST OF FIGURES (Continued)}

$\underline{\text { Page }}$

Figure 2.12 Polarization Curve For Alloy 304L in Simulated J-13 Well Water At $90^{\circ} \mathrm{C}$ Run At A Scan Rate Of $0.6 \mathrm{~V} / \mathrm{hr}$ (Beavers-1989) $\ldots \ldots \ldots \ldots . . .21$

Figure 2.13 Polarization Curve For Alloy 825 In Simulated J-13 Well Water At $90^{\circ} \mathrm{C}$ Run At A Scan Rate Of $0.6 \mathrm{~V} / \mathrm{hr}$ (Beavers-1989) . . . . . . . 21

Figure 2.14 Polarization Curve For Alloy $825 \ln$ Test Solution No. 20 At $90^{\circ} \mathrm{C}$ (Beavers-1990) . . . . . . . . . . . . . . . . . . . . . 24

Figure 2.15 Polarization Curve For Alloy 304L In Test Solution No. 20 At $90^{\circ} \mathrm{C}$ (Beavers-1990) . . . . . . . . . . . . . . . . . . . 24

Figure 2.16 Polarization Curve For Alloy CDA 102 In Test Solution No. 7 At $90^{\circ} \mathrm{C}$ (Beavers-1990a) . . . . . . . . . . . . . . . . . . . 25

Figure 2.17 Polarization Curve For Alloy CDA 715 in Test Solution No. 7 At $90^{\circ} \mathrm{C}$ (Beavers-1989a) ....................... 25

Figure 3.1 Glass Resin Kettles Used In The Task 3 Immersion Studies . . . . . . . 29

Figure 3.2 CPP Curve For Alloy CDA 102 In Simulated J-13 Well Water Showing The Anodic And Cathodic Tafel Slope Determinations (Beavers-1990)

Figure 3.3 Schematic Showing Weight Change As A Function Of Descaling Time For Control (Unexposed) And Test Specimen . . . . . . . . . . . . . 32

Figure 4.1 Polarization Resistance As A Function Of Test Time For Specimens Of Alloy 304L in The Liquid And Vapor Phase Of Aerated Simulated $\mathrm{J}-13$ Well Water At $90^{\circ} \mathrm{C} \ldots \ldots \ldots \ldots . \ldots . \ldots$

Figure 4.2 Polarization Resistance As A Function Of Test Time For Specimens Of Alloy 825 In The Liquid And Vapor Phase Of Aerated Simulated $\mathrm{J}-13$ Well Water At $90^{\circ} \mathrm{C}$

Figure 4.3 Corrosion Potential As A Function Of Test Time For Alloy 304L And Alloy 825 Exposed To The Liquid Phase Of Aerated Simulated $\mathrm{J}-13$ Well Water At $90^{\circ} \mathrm{C} \ldots \ldots \ldots \ldots . \ldots . \ldots 38$

Figure 4.4 Polarization Resistance As A Function Of Test Time For Specimens Of Alloy CDA 102 In The Liquid And Vapor Phase Of Aerated Simulated $\mathrm{J}-13$ Well Water At $90^{\circ}$ 


\section{LIST OF FIGURES (Continued)}

Page

Figure 4.5 Polarization Resistance As A Function Of Test Time For Specimens Of Alloy CDA 715 In The Liquid And Vapor Phase Of Aerated Simulated J -13 Well Water At $90^{\circ} \mathrm{C} \ldots \ldots \ldots . . . \ldots . . . . .46$

Figure 4.6 Corrosion Potential As A Function Of Test Time For Alloy CDA 715 And Alloy CDA 102 Exposed To The Liquid Phase Of Aerated Simulated J-13 Well Water At $90^{\circ} \mathrm{C}$

Figure 4.7 Scanning Electron Microscope (SEM) Photographs Of Creviced CDA 715 Specimen Exposed In The Vapor Phase Above Aerated Simulated J-13 Well Water For 2024 Hours . . . . . . . . . . . 49

Figure 5.1 Polarization Resistance As A Function Of Test Time For Specimens Of Alloy 304L In The Liquid And Vapor Phase Of Aerated Solution No. 20 At $90^{\circ} \mathrm{C}$ (Prior To $\mathrm{H}_{2} \mathrm{O}_{2}$ Additions Or Following $\mathrm{H}_{2} \mathrm{O}_{2}$ Decay (2500 Hour Data))

Figure 5.2 Polarization Resistance As A Function Of Test Time For Specimens Of Alloy 825 In The Liquid And Vapor Phase Of Aerated Solution No. 20 At $90^{\circ} \mathrm{C}$ (Prior To $\mathrm{H}_{2} \mathrm{O}_{2}$ Additions Or Following $\mathrm{H}_{2} \mathrm{O}_{2}$ Decay (2500 Hour Data)) . . . . . . . . . . . 58

Figure 5.3 Corrosion Potential As A Function Of Test Time For Alloy 304L And Alloy 825 Exposed To The Liquid Phase Of Aerated Solution No. 20 At $90^{\circ} \mathrm{C}$ (Prior To $\mathrm{H}_{2} \mathrm{O}_{2}$ Additions Or Following $\mathrm{H}_{2} \mathrm{O}_{2}$ Decay (2500 Hour Data)) . . . . . . . . . . . . . . . 59

Figure 5.4 Polarization Curve For Alloy 304L In Test Solution No. $20 \mathrm{At}$

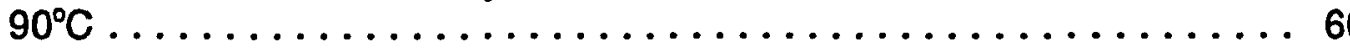

Figure 5.5 Polarization Curve For Alloy 825 In Test Solution No. 20 At $90^{\circ} \mathrm{C}$.

Figure 5.6 Corrosion Potential As A Function Of Test Time For Alloy 304L In Solution No. 20 At $90^{\circ} \mathrm{C}$ Showing The Effects $\mathrm{Of}_{2} \mathrm{H}_{2}$ Additions

Figure 5.7 Corrosion Potential As A Function Of Test Time For Alloy 825 In Solution No. 20 At $90^{\circ} \mathrm{C}$ Showing The Effects of $\mathrm{H}_{2} \mathrm{O}_{2}$ Additions 


\section{LIST OF FIGURES (Continued)}

Page

Figure 5.8 Corrosion Rate As A Function $\mathrm{Of}_{2} \mathrm{H}_{2}$ Concentration Calculated From Polarization Resistance Measurements For Alloy 825 And Alloy $304 \mathrm{~L}$ in Solution No. 20 At $90^{\circ} \mathrm{C} \ldots \ldots \ldots \ldots \ldots \ldots \ldots . \ldots 6$

Figure 5.9 Photomicrograph Of Alloy 304L U-bend Specimen Following 2855 Hours Of Exposure To Solution No. 20 (With $\mathrm{H}_{2} \mathrm{O}_{2}$ Additions) At $90^{\circ} \mathrm{C}$ Showing Stress-Corrosion Cracking; $7 X$ Magnification ............................6 67

Figure 5.10 Photomicrograph Of Alloy 304L U-Bend Specimen Following 2855 Hours Of Exposure To Solution No. 20 (With $\mathrm{H}_{2} \mathrm{O}_{2}$ Additions) At $90^{\circ} \mathrm{C}$ Showing Transgranular Stress-Corrosion Cracking; 250X Magnification

Figure 6.1 Polarization Resistance As A Function Of Test Time For Specimens Of Alloy CDA 102 in The Liquid And Vapor Phase Of Aerated Solution No. 7 At $90^{\circ} \mathrm{C} \ldots \ldots \ldots \ldots \ldots \ldots \ldots \ldots . \ldots . \ldots . \ldots$

Figure 6.2 Polarization Resistance As A Function Of Test Time For Specimens Of Alloy CDA 715 In The Liquid And Vapor Phase Of Aerated Solution No. 7 At $90^{\circ} \mathrm{C} \ldots \ldots \ldots \ldots \ldots \ldots . \ldots . \ldots . \ldots . \ldots$

Figure 6.3 Corrosion Potential As A Function Of Test Time For Alloy CDA 102 And Alloy CDA 715 Exposed To The Liquid Phase Of Aerated Solution No. 7 At $90^{\circ} \mathrm{C} \ldots \ldots \ldots \ldots \ldots \ldots \ldots . \ldots . \ldots . \ldots$

Figure 6.4 Polarization Curve For Alloy CDA 102 In Test Solution No. 7 At

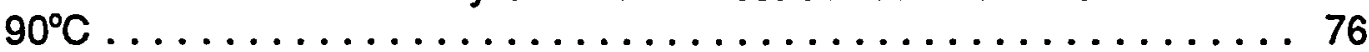

Figure 6.5 Polarization Curve For Alloy CDA 715 In Test Solution No. 7 At $90^{\circ} \mathrm{C}$.

Figure 7.1 Electrochemical Determinations Of Corrosion Rates For Different Alloys In Tuff-Conditioned J-13 Well Water At $100^{\circ} \mathrm{C}$ (McCright1984)

Figure 7.2 Potentiodynamic Anodic Polarization Curve For Alloy 304L In J-13 Well Water At $90^{\circ} \mathrm{C}$. Scan Rate Was $1 \mathrm{mV} / \mathrm{s}$. Scan Starts From $E_{\text {cor }}$ (Glass-1984) ...................... 81

Figure 7.3a Electrochemical Parameters For Alloy 304L In Tuff-Conditioned J-13 Well Water As A Function Of Temperature (Glass-1984) . . . . . . 82 


\section{LIST OF FIGURES (Continued)}

Page

Figure 7.3b Electrochemical Parameters For Alloy 825 in Tuff-Conditioned J-13 Well Water As A Function Of Temperature (Glass-1984). . . . . . . 82

Figure 7.4 Corrosion Rates In J-13 And 100X Concentrated J-13 As A Function Of Temperature; ${ }^{*}=100 \mathrm{X}$ J-13 (McCright-1985) $\ldots \ldots \ldots \ldots .86$

Figure 7.5 Polarization Behavior Of Alloy CDA 715 in J-13 Well Water At $80^{\circ} \mathrm{C}$ At A Scan Rate Of $1 \mathrm{Mv} / \mathrm{sec}$ (McCright-1985) . . . . . . . . 88

Figure A.1 Schematic Of Typical Anodic Potentiodynamic Polarization Curves .................................. 98

Figure A.2 Electrochemical Cell Used For Ambient Pressure Potentiodynamic Polarization Experiments 99 


\section{LIST OF TABLES}

Page

Table 2.1 Percentages Of Major Constituents In Topopah Springs Tuff, Drill Core USW GU-3, Samples 60, 61, And 62. $\mathrm{Fe}_{2} \mathrm{O}_{3}$ Represents Total Iron (Schuraytz-1985) $\ldots \ldots \ldots \ldots \ldots \ldots \ldots \ldots$

Table 2.2 Chemical Composition Of Test Solutions At The End Of Corrosion Tests $(\mu / \mathrm{ml})$ (Undiluted And Filtered Solution)

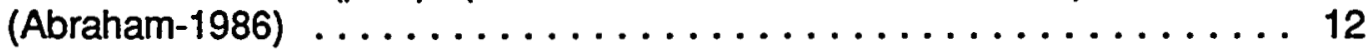

Table 2.3 Chemical Composition Of Simulated Tuff Groundwater And J-13 Well Water From Yucca Mountain, Nevada (For Comparison) ....... 15

Table 2.4 Composition Of J-13 Well Water And Selected Solutions From The Experimental Matrix

Table 2.5 Summary Of The Polarization Parameters For Selected Alloys In Simulated J-13 Well Water, Solution No. 20 And Solution No.

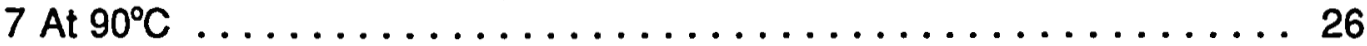

Table 3.1 Summary Of Specimens Used In The Task 3 Immersion Studies ................................. 28

Table 4.1 Summary Of Results Of 510, 1011, and 2039 Hour Exposures Of Fe-Cr-Ni Alloys In Aerated Simulated J-13 Well Water At

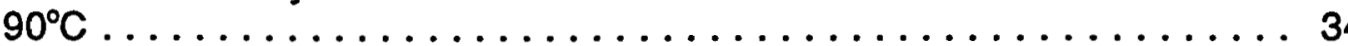

Table 4.2 Summary Of Results Of Electrochemical Measurements Performed On Fe-Cr-Ni Alloys In Aerated Simulated J-13 Well

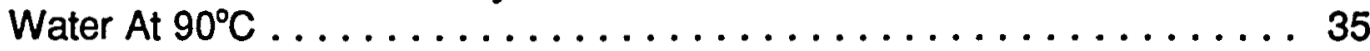

Table 4.3 Estimated Upper Limit Polarization Resistance Values As A Function Of Specimen Surface Area And Test Procedure .......... 39

Table 4.4 Summary Of Results Of 2024 Hour Exposures Of Copper-Base Alloys In Aerated Simulated J-13 Well Water At $90^{\circ} \mathrm{C} \ldots \ldots \ldots \ldots 42$

Table 4.5 Summary Of Results Of Electrochemical Measurements Performed On Copper-Base Alloys In Aerated Simulated J-13 Well Water At $90^{\circ} \mathrm{C} \ldots \ldots \ldots \ldots \ldots \ldots \ldots \ldots \ldots \ldots \ldots \ldots$

Table 4.6 Summary Of Environments Known To Promote Stress-Corrosion Cracking Of Copper-Base Alloys (Beavers-1990a) ............ 51 


\section{LIST OF TABLES (Continued)}

Page

Table 5.1 Chemical Composition Of J-13 Well Water And Solution No. 20

From The Experimental Test Matrix $. . \ldots \ldots \ldots \ldots \ldots \ldots \ldots . \ldots . \ldots 3$

Table 5.2 Summary Of Results Of Exposure Of Creviced Spećimens Of

Alloy $304 \mathrm{~L}$ In Aerated Solution No. 20 At $90^{\circ} \mathrm{C}$............... 54

Table 5.3 Summary Of Results Of Exposure Of Creviced Specimens Of

Alloy 825 in Aerated Solution No. 20 At $90^{\circ} \mathrm{C}$............... 55

Table 5.4 Summary Of Results Of Electrochemical Measurements Performed In Aerated Solution No. 20 At $90^{\circ} \mathrm{C} \ldots \ldots \ldots \ldots \ldots . \ldots 6$

Table 5.5 Summary Of Results Of Electrochemical Measurements Five Minutes Following $\mathrm{H}_{2} \mathrm{O}_{2}$ Additions To Aerated Solution No. 20 At $90^{\circ} \mathrm{C}$

Table 6.1 Chemical Composition Of J-13 Well Water And Solution No. 7

From The Experimental Test Matrix .................. 69

Table 6.2 Summary Of Results Of 2014 Hour Exposures Of Creviced Specimens Of The Copper-Base Alloys In Aerated Solution

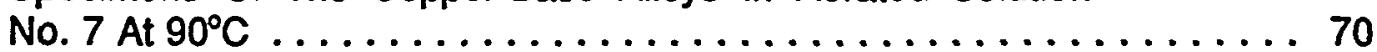

Table 6.3 Summary Of Results Of Electrochemical Measurements Performed On Copper-Base Alloys In Aerated Solution No. 7 At

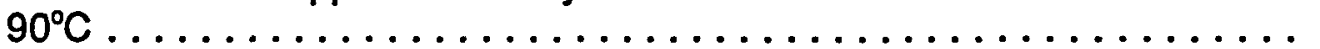

Table 7.1 Corrosion Test Results For Different Steel Coupons Exposed To $100^{\circ} \mathrm{C}$ Tuff-Conditioned Water And Steam; 1000 Hour Exposure Of Triplicate Coupons (McCright-1984)

Table 7.2 General Corrosion Penetration Rates Of Candidate Copper-Base Materials And Other Materials, For Comparison, In Tuff Repository Environmental Conditions (McCright-1985) ........... 85

Table 7.3 Summary Of Environments Known To Promote Stress-Corrosion Cracking Of Copper-Base Alloys (Beavers-1990a) 90

Table B.1 Concentration Ranges For Environmental Species In Tuff Groundwater ... 


\section{LIST OF TABLES (Continued)}

Page

Table B.2 List Of Variables Included In The Matrix Of Potentiodynamic

Polarization Tests In Task 2 (Beavers-1989) ............... 103

Table B.3 Series Of Tests Included In The Matrix Of Potentiodynamic

Polarization Tests In Task 2 (Beavers - 1989) ................ 104 
Cortest Columbus Technologies (CC Technologies) is investigating the long-term performance of container materials used for high-level radioactive waste packages. This information is being developed for the Nuclear Regulatory Commission to aid in their assessment of the Department of Energy's application to construct a geologic repository for disposal of high-level radioactive waste. The scope of work consists of employing short-term techniques, such as electrochemical and mechanical techniques to examine a wide range of possible failure modes. Long-term tests are being used to verify and further examine specific failure modes identified as important by the short-term studies.

This report summarizes the results of exposure studies performed in Task 3 of the program, in which candidate container materials were evaluated in simulated groundwater for the Tuff Repository. The purpose of Task 3 was to evaluate the corrosion behavior of the container materials in the Tuff Repository at times when the temperatures are near the boiling point of water and periodic intrusion of vadose water occurs. Specimens were exposed at $90^{\circ} \mathrm{C}$ to the liquid, to the vapor above the condensed phase, to alternate immersion, and to the vapor-liquid interface.

Two classes of alloys were evaluated for use as container materials for the Tuff Repository; Fe$\mathrm{Cr}-\mathrm{Ni}$ alloys and copper-base alloys. The candidate $\mathrm{Fe}-\mathrm{Cr}-\mathrm{Ni}$ alloys were Type $304 \mathrm{~L}$ Stainless Steel (Alloy 304L) and Incoloy Alloy 825 (Alloy 825). The candidate copper-base alloys were CDA 102 Copper (Alloy CDA 102) and Copper-30 Nickel (Alloy CDA 715).

In this study, three environments were evaluated in simulated J-13 well water, and two other solutions (Solution No. 20 and Solution No. 7) that were designed to simulate the chemical effects resulting from concentration and irradiation of the groundwater. Each of the candidate alloys was evaluated in the simulated $\mathrm{J}-13$ well water. The Fe-Cr-Ni alloys were evaluated in Solution No. 20, a solution that was found to be a pitting environment for these alloys. The copper-base alloys were evaluated in Solution No. 7, a solution that was found to be an active corrosion environment for these alloys. An initial assessment of the corrosion behavior of the alloys in the environments was determined from cyclic potentiodynamic polarization curves.

Both general and localized corrosion were evaluated in the exposure studies. Creviced specimens as well as U-bends were included in the study. The specimens were evaluated by electrochemical (polarization resistance) techniques, as well as gravimetric and metallographic techniques. In all of the testing, the polarization resistance (PR) technique overestimated the corrosion rate as compared with weight-loss measurements. This overestimation of the corrosion rate may be attributed to the occurrence of spurious (non-corrosion) electrochemical reactions in the test environments.

The general corrosion rates for both of the Fe-Cr-Ni alloys (vapor, liquid, and alternate immersion specimens), after approximately 2000 hours of exposure to simulated $\mathrm{J}-13$ well water at $90^{\circ} \mathrm{C}$, were below the detection limits $(<0.2 \mu \mathrm{m} / \mathrm{yr})$. Blue interference films were observed on most of the specimens prior to descaling, which indicates that some passive film growth had occurred during the tests. Some etching was observed beneath the deposits and around the crevice washers on both of the alloys. Some shallow pits were found on several of the Alloy 825 specimens where deposits had accumulated. However, the pit depth did not increase with time of exposure, which suggests that either the rate of pit propagation decreases with time or that 
propagation ceased. Long-term testing is needed to investigate this phenomenon further as Alloy 825 would be expected to be resistant to pitting in the simulated J-13 well water. No stresscorrosion cracking (SCC) was observed for either $\mathrm{Fe}-\mathrm{Cr}$-Ni alloy after 2039 hours of exposure in simulated $\mathrm{J}-13$ well water.

General corrosion rates for the $\mathrm{Fe}-\mathrm{Cr}-\mathrm{Ni}$ alloys were also very low $(<0.5 \mu \mathrm{m} / \mathrm{y})$ after approximately 2000 hours of exposure to a pitting environment (Solution No. 20) at $90^{\circ} \mathrm{C}$. As in the simulated $\mathrm{J}-13$ well water, some slight etching was observed beneath deposits and around the crevice washers. To study the effects of radiolysis on the corrosion behavior of these alloys, hydrogen peroxide $\left(\mathrm{H}_{2} \mathrm{O}_{2}\right)$, was added after approximately 2200 hours of exposure. The $\mathrm{H}_{2} \mathrm{O}_{2}$ was found to promote pitting of Alloy 304L near to and under crevices to a depth of $63 \mu \mathrm{m}$ in this environment. On the other hand, shallow pitting $(10 \mu \mathrm{m})$ was observed on only one liquid-phase specimen of Alloy 825 as a result of addition of $\mathrm{H}_{2} \mathrm{O}_{2}$.

In Solution No. 20, transgranular stress-corrosion cracking (SCC) was noted, at the conclusion of the test, in vapor-phase U-bend specimens of Alloy 304L. The cracking appeared to originate from deep pits in the stressed portions of the specimens. No SCC was observed in any of the specimens of Alloy 825.

The copper-base alloys showed acceptable rates of general corrosion after 2024 hours of exposure to simulated $\mathrm{J}-13$ well water at $90^{\circ} \mathrm{C}$. The corrosion rates of Alloy CDA 102 specimens were about an order of magnitude higher than those of Alloy CDA 715 specimens. For both alloys, the rates of corrosion remained reasonably constant for the first 1000 hours of exposure, but decreased thereafter. After 2024 hours, vapor, liquid; and alternate immersion specimens of Alloy CDA 102 all exhibited comparable corrosion rates of about $2.5 \mu \mathrm{m} / \mathrm{y}$, which corresponds to a thickness loss of 0.1 inches in 1000 years.

Some pitting was noted on specimens of Alloy CDA 102 in simulated $\mathrm{J}-13$ well water at $90^{\circ} \mathrm{C}$; the deepest pits $(34 \mu \mathrm{m})$ occurring in the vapor phase. Deeper pits, up to $53 \mu \mathrm{m}$, were noted on specimens of Alloy CDA 715 in the vapor near the vapor-liquid interface. In simulated J-13 well water, rates of pitting of Alloy CDA 102 exhibited scatter but appeared to decrease with time over the first 2000 hours of exposure whereas, for Alloy CDA 715, rates of pitting clearly increased with exposure time. Pitting and etching was also found on U-bend specimens. However, no SCC occurred in either of the copper-base alloys.

Corrosion rates of the copper-base alloys were significantly higher in an active corrosion environment (Solution No. 7) at $90^{\circ} \mathrm{C}$ than in the simulated $\mathrm{J}-13$ well water. Alloy CDA 102 exhibited etching in the vapor phase and severe etching and pitting in the liquid phase. The overall rates of general corrosion decreased with exposure time and was less than $25 \mu \mathrm{m} / \mathrm{yr}$ after 2000 hours. Pitting was severe, up to $147 \mu \mathrm{m}$ in depth, but rates of pitting decreased with time.

Alloy CDA 715 exhibited slightly less corrosion than Alloy CDA 102 in Solution No. 7. Shallow pitting and etching was observed in the vapor phase, whereas severe pitting and etching occurred in the liquid phase. As with Alloy CDA 102, the overall corrosion rate decreased with exposure time $(<15 \mu \mathrm{m} / \mathrm{yr})$, but pitting was severe. Pits as deep as $98 \mu \mathrm{m}$ were measured at the completion of the exposure. The rate of pitting appeared to decrease with exposure time. Pitting and etching were also observed on U-bend specimens, but as in the simulated J-13 environment, no SCC was found to occur for either copper-base alloy. 


\section{INTRODUCTION}

The Department of Energy (DOE) is conducting a program for the disposal of high-level radioactive waste in a deep-mined geologic repository. The Nuclear Regulatory Commission (NRC), which is responsible for regulating high-level radioactive waste disposal, will review DOE's application for the construction and operation of the repository. To assist in evaluating DOE's application, the NRC's Office of Nuclear Regulatory Research is developing an understanding of the long-term performance of the geologic repository. As part of this effort, Cortest Columbus Technologies has been awarded a contract to investigate the long-term performance of container materials used for high-level waste packages. At the direction of the NRC, the program is focused on the Tuff Repository.

The scope of work consists of employing relatively short-term electrochemical techniques to examine a wide range of possible failure modes. Long-term tests (1-2 years) are being used to verify the short-term studies.

This report summarizes the results of exposure studies performed in Task 3 of the program in which candidate container materials were evaluated in simulated groundwater for the Tuff Repository. The purpose of Task 3 was to evaluate the corrosion behavior of the container materials in the Tuff Repository at times when temperatures are near the boiling point of water and periodic intrusion of vadose water occurs. Specimens were exposed to the liquid, vapor above the condensed phase, alternate immersion, and at the vapor-liquid interface. The focus of the Task 3 studies was to evaluate both general and localized corrosion. Creviced specimens as well as U-bends were included in the study. Testing was performed at $90^{\circ} \mathrm{C}$ in simulated repository environments. 


\section{BACKGROUND - THE TUFF REPOSITORY ENVIRONMENT}

\subsection{Nominal Environment}

The Tuff repository will be located in the Topopah Spring Member of the Paintbrush Tuff under Yucca Mountain, 100 miles northwest of Las Vegas, Nevada in the Nevada Test Site (NTS). The site is located in an extremely arid zone with about $15 \mathrm{~cm} /$ year annual precipitation. The evaporation-transpiration rates also are very high so the net water percolating down from the surface is of the order of a few millimeters per year (Montazer - 1984).

Tuff is an igneous rock of volcanic origin and is composed of volcanic rock fragments (shards) and ash. The structure of the tuff deposits depends on the cooling rate and degree of compaction after the volcanic eruption. The rock shards weld together and the compacted material may remain glassy or may devitrify. A layered structure develops; a densely welded core surrounded above and below by zones of material decreasing in density and strength. In the postdepositional period, alteration of the tuff layers occurs. Crystallization transforms the glassy material to feldspar plus quartz or cristobalite. Zeolitization produces hydrous silicates by reaction of the glassy material with groundwater. A typical stratigraphy of the tuff at the NTS is shown in Figure 2.1. A more detailed description of these tuff layers is found in Johnstone-1981.

The potential repository horizon is in the lower, densely welded and devitrified portion of the Topopah Spring Member located 700 to 1400 feet above the static water table. The bulk rock at the horizon is composed of rhyolite with a small range in composition as shown in Table 2.1. This small variation in geochemistry demonstrates that the host rock may be considered uniform, according to Glassley-1986.

A reference water used in many repository studies has been taken from Well $\mathrm{J}-13$. That well is located near the repository site and produces water which has flowed through the Topopah Spring Member, where it lies at a lower elevation and is in the saturated zone. The J-13 well water is the best available source of water from the Topopah Spring Member, but may not be a good approximation of the actual water that will be present in the repository.

The location of the repository above the static water table has a major impact on the anticipated environment. First of all, the environment will be aerated; the $\mathrm{J}-13$ well water contains $5.7 \mathrm{ppm}$ dissolved oxygen which probably represents a lower limit for oxygen. This condition is unique in that the plans for all other repositories, either in the United States or elsewhere, have called for locations below the static water table where conditions are deaerated (anoxic).

A second feature of the location of the repository above the water table is the elimination of the hydrostatic head on the waste container. At the repository elevation, the boiling point for water is about $95^{\circ} \mathrm{C}$, and thus the environment at the waste package surface will be steam and air during the early life of the repository. 


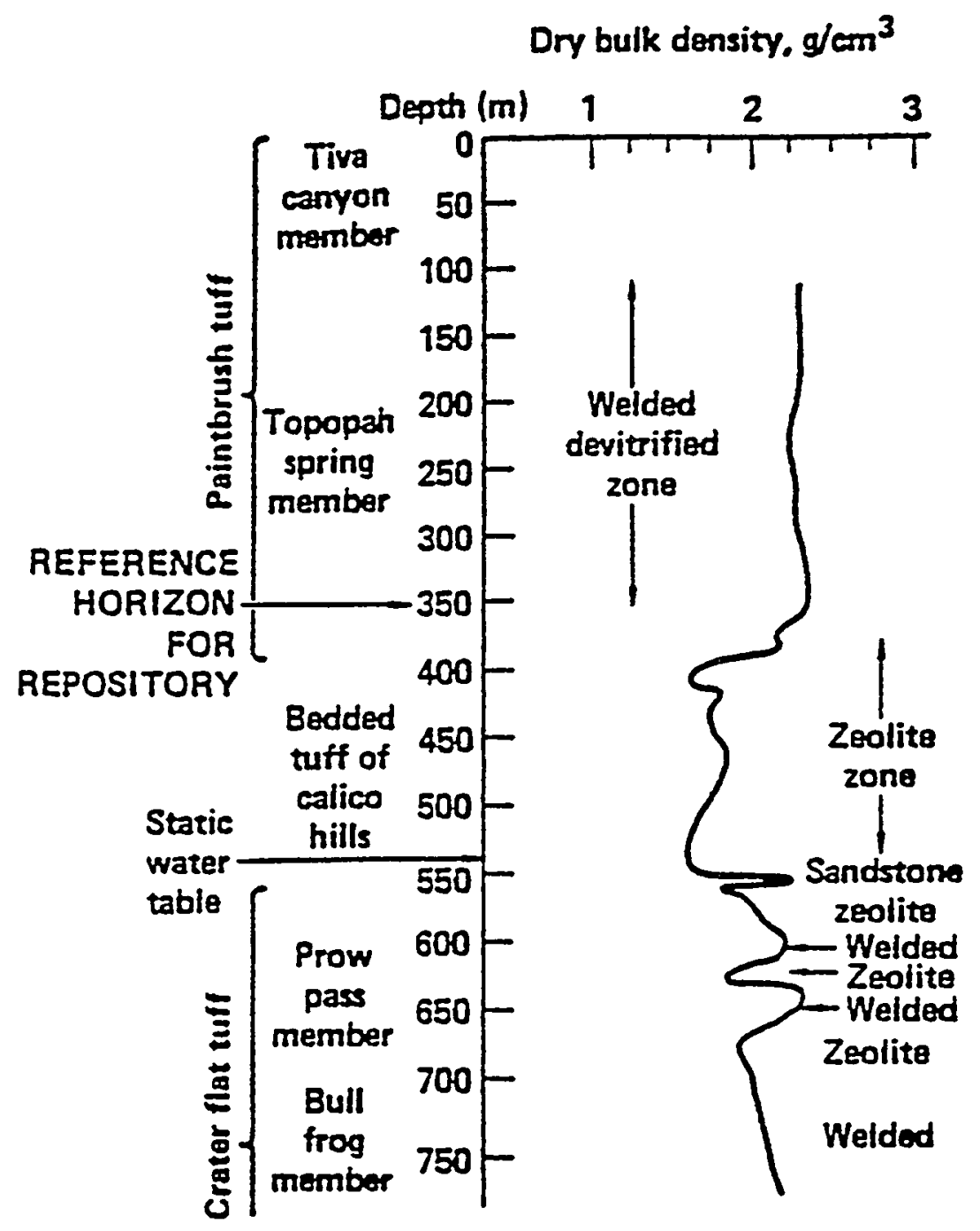

(Drillhole UE $25 a-1)$

Figure 2.1 Representative Stratigraphic Section In Nevada Tuff (Drillhole UE25 a-1) (McCright-1984). 
Table 2.1 Percentages Of Major Constituents In Topopah Springs Tuff, Drill Core USW GU-3, Samples 60, 61 And 62. $\mathrm{Fe}_{2} \mathrm{O}_{3}$ Represents Total Iron (Schuraytz-1985).

\begin{tabular}{||l|l|l|l|l|l||}
\hline Constituent & 60 & 61 & 62 & Average & Std Dev \\
\hline $\mathrm{SiO}_{2}$ & 78.4 & 78.9 & 78.9 & 78.73 & 0.24 \\
$\mathrm{Al}_{2} \mathrm{O}_{3}$ & 12.0 & 12.3 & 12.2 & 12.17 & 0.12 \\
$\mathrm{Fe}_{2} \mathrm{O}_{3}$ & 1.016 & 0.973 & 1.000 & 0.996 & 0.018 \\
$\mathrm{CaO}$ & 0.492 & 0.451 & 0.480 & 0.474 & 0.017 \\
$\mathrm{MgO}$ & 0.1271 & 0.1281 & 0.1126 & 0.123 & 0.007 \\
$\mathrm{THO}_{2}$ & 0.1108 & 0.0927 & 0.0984 & 0.101 & 0.008 \\
$\mathrm{Na}_{2} \mathrm{O}$ & 4.07 & 3.92 & 4.25 & 4.08 & 0.13 \\
$\mathrm{~K}_{2} \mathrm{O}$ & 3.71 & 3.18 & 2.94 & 3.28 & 0.32 \\
$\mathrm{P}_{2} \mathrm{O}_{2}$ & 0.01 & 0.01 & 0.03 & 0.02 & 0.01 \\
$\mathrm{MnO}^{\mathrm{MnO}}$ & 0.0624 & 0.0455 & 0.0488 & 0.052 & 0.007 \\
\hline
\end{tabular}




\subsubsection{Thermal Effects}

The repository is being designed for two types of waste packages; spent fuel and processed defense high level waste in the form of borosilicate glass. The spent fuel will have the highest thermal output of between 1.3 and $3.3 \mathrm{Kw}$ per container, while the glass will have an output of 0.25 to $0.47 \mathrm{Kw}$ per container. The temperature histories of the waste packages are sensitive functions of the thermal properties of the near-field rock, the specific configuration of boreholes and emplacement drifts, heat transfer mode as well as container output power; none of these factors has been precisely defined. Comparative canister surface temperatures as a function of time are shown in Figure 2.2 for one set of conditions. Note that the canister surface for spent fuel remains above the boiling temperature over at least a 300 year period following emplacement.

These elevated temperatures should exclude liquid water from the near field of the repository for several hundred years, although liquid water may be present in the pores in the rock up to $140^{\circ} \mathrm{C}$. It is also possible that vadose water may come in contact with some of the waste packages during periods of liquid water movement through the repository.

A consequence of the elevated temperature in the repository will be the interaction of groundwater with the host rock in the vicinity of the waste package. A number of interaction studies has been performed over temperatures ranging from $90-250^{\circ} \mathrm{C}$ with core wafers, crushed core wafers in gold-bags and PTFE-lined (polytetrafluoroethylene) autoclaves. Rapid shifts in chemistry occurred with crushed rock as opposed to wafers because of the higher surface area with the former. Changes in solution concentration at $90^{\circ} \mathrm{C}$ were minor; whereas, more pronounced shifts occurred at $150^{\circ} \mathrm{C}$. Results obtained by Knauss -1985 a for crushed core material at $150^{\circ} \mathrm{C}$ are given in Figures 2.3 and 2.4. These data show that the silicon (Si) concentrations increased from about $30 \mathrm{ppm}$ to around $150 \mathrm{ppm}$ within 60 days, while the sodium $(\mathrm{Na})$ concentration only increased slightly over the test period. The concentrations of aluminum* (Al), magnesium $(\mathrm{Mg})$ and calcium (Ca) decreased with time while that of potassium ${ }^{*}(K)$ was not greatly affected by thermal interaction; the $\mathrm{pH}$ decreased very slightly.

Another consequence of the elevated temperatures in the repository will be the boiling of groundwater in the vicinity of the waste package. This will lead to the concentration of the species, both beneficial and deleterious in the groundwater. Abraham (1986) has performed some solution analyses on boiling J-13 groundwaters at Brookhaven National Laboratory. The solutions were boiled in the presence of tuff rock and specimens of several stainless steels. The results are summarized in Table 2.2. These data show that the composition of $\mathrm{J}-13$ water changed quite dramatically as a result of boiling. The stable concentrations of most species after one year were more than an order of magnitude higher than those in the $\mathrm{J}-13$ well water. Some species, such as $\mathrm{SO}_{4}{ }^{2-}, \mathrm{NO}^{3-}, \mathrm{Ca}^{2+}$ and $\mathrm{K}^{+}$exhibited a maximum in concentration after only a few months which suggests the precipitation of compounds such as $\mathrm{CaSO}_{4}$, etc.

*Both aluminum and potassium exhibited initial transient increases in concentrations. 


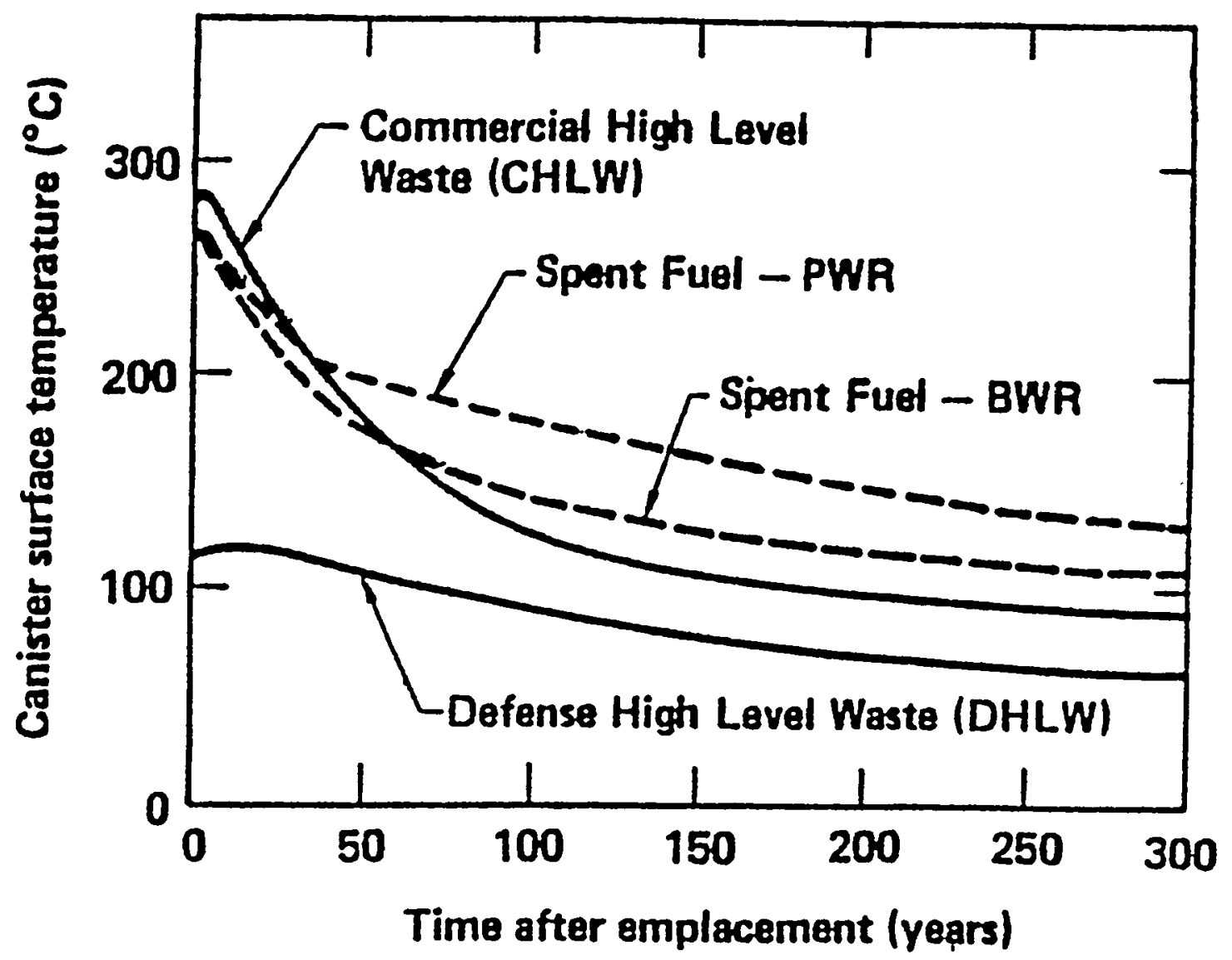

Figure 2.2 Comparative Canister Surface Temperature-Time Profiles For Different Waste Packages In A Tuff Repository (Vertical Emplacement, $50 \mathrm{~kW} / \mathrm{acre}$ Areal Loading) (McCright-1984). 


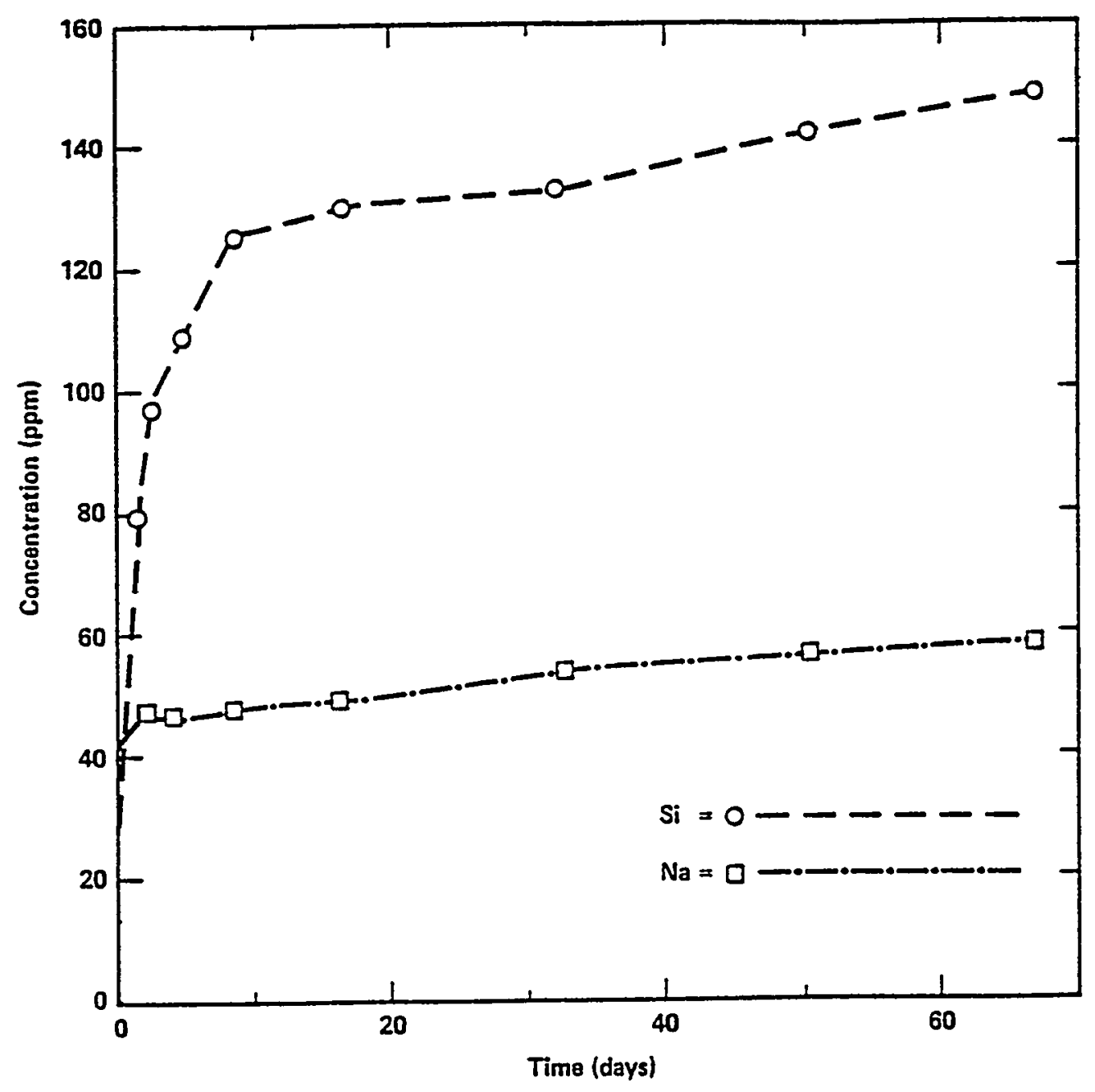

Figure 2.3 Silicon And Sodium Concentrations In J-13 Well Water Reacted With Crushed G-1 Material At $150^{\circ} \mathrm{C}$ As A Function Of Time In Days (Knauss-1985a). 


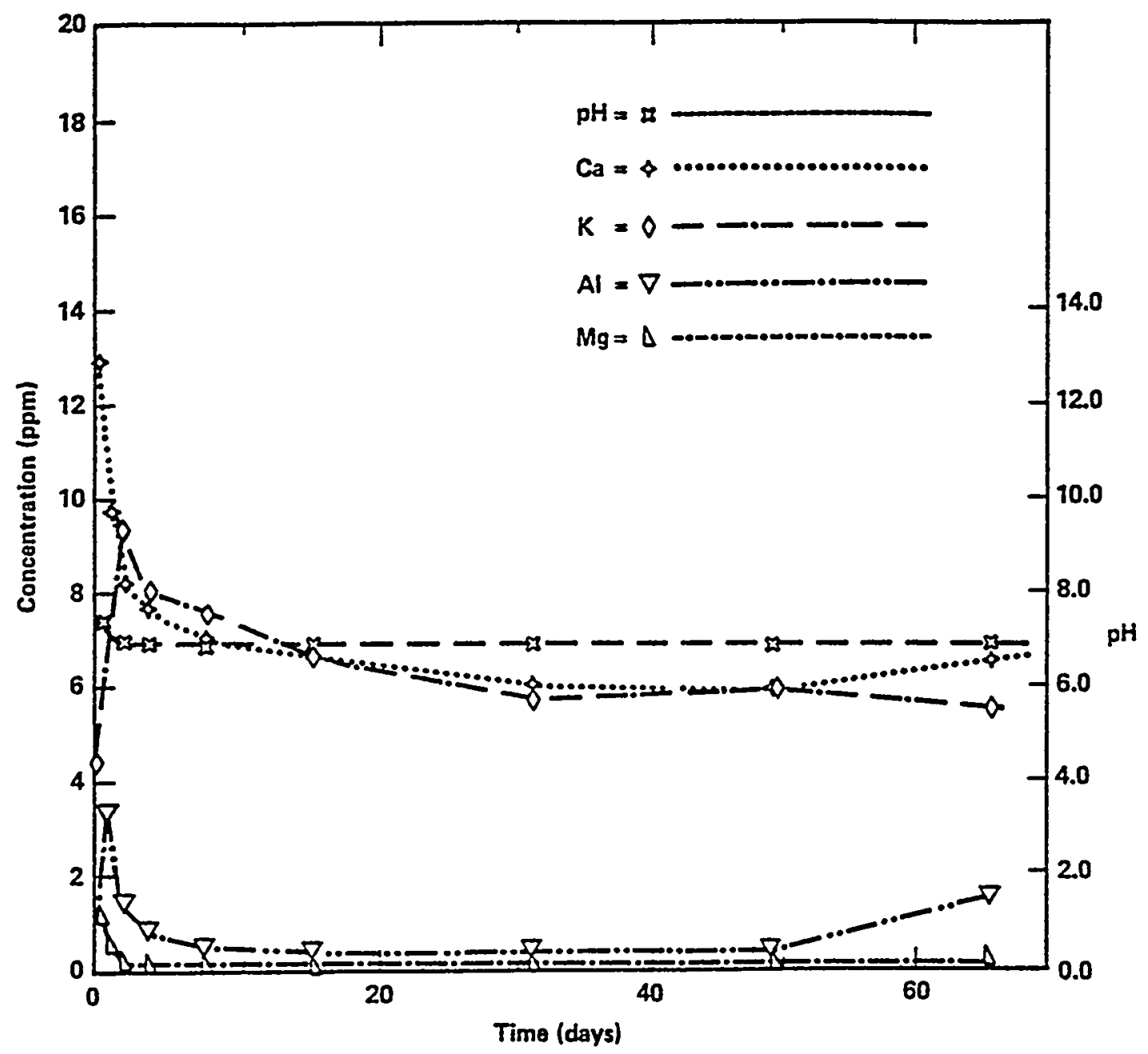

Figure 2.4 Aluminum, Potassium, Calcium, Magnesium, And pH Analyses From J-13 Wen Water Reacted With Crushed G-1 Material At $150^{\circ} \mathrm{C}$ As A Function Of Time In Days (Knauss-1985a). 
Table 2.2 Chemical Composition Of Test Solutions At The End Of Corrosion Tests $(\mu \mathrm{g} / \mathrm{ml})$ (Undiluted And Filtered Solution) (Abraham-1986).

\begin{tabular}{|c|c|c|c|c|c|c|c|}
\hline & \multirow{2}{*}{$\begin{array}{c}\text { Reference } \\
\text { J-13 } \\
\text { Ground- } \\
\text { water }\end{array}$} & \multicolumn{3}{|c|}{ Synthetic J-13 Water } & \multicolumn{3}{|c|}{$\begin{array}{c}\text { 10-Times Conc. } \\
\mathrm{J}-13 \text { Water }\end{array}$} \\
\hline & & $\begin{array}{l}\text { 3-Mo. } \\
\text { Test }\end{array}$ & $\begin{array}{l}\text { 6-Mo. } \\
\text { Test }\end{array}$ & $\begin{array}{l}1-Y r . \\
\text { Test }\end{array}$ & $\begin{array}{l}\text { 3-Mo. } \\
\text { Test }\end{array}$ & $\begin{array}{l}\text { 6-Mo. } \\
\text { Test }\end{array}$ & $\begin{array}{l}1-Y r . \\
\text { Test }\end{array}$ \\
\hline $\mathrm{Na}^{+}$ & 45 & N.D.* & 464 & 510 & 867 & 738 & 908 \\
\hline $\mathrm{K}^{+}$ & 4.9 & 238 & 244 & 106 & 244 & 214 & 139 \\
\hline $\mathrm{Ca}^{2+}$ & 14 & 308 & 161 & 104 & 301 & 164 & 129 \\
\hline $\mathrm{Sn}^{2+}$ & N.D. & 3.4 & 0.4 & 1.0 & 4.4 & 0.5 & 1.2 \\
\hline$F^{-}$ & 2.2 & 12.1 & 4 & 6.31 & 14 & 5 & 21.1 \\
\hline $\mathrm{Cl}^{-}$ & 7.5 & 130 & 236 & 161 & 330 & 211 & 260 \\
\hline $\mathrm{NO}_{3}^{-}$ & 5.6 & 460 & 750 & 482 & --- & 522 & 672 \\
\hline $\mathrm{SO}_{4}^{2-}$ & 22 & 820 & 552 & 588 & 1300 & 1260 & 976 \\
\hline $\mathrm{SiO}_{2}$ & 61 & 414 & 451 & 458 & 408 & 488 & 406 \\
\hline $\begin{array}{l}\mathrm{pH} \text { at room } \\
\text { temperature }\end{array}$ & 8.5 & 8.4 & 9.0 & 9.3 & 8.4 & 8.9 & 9.3 \\
\hline${ }^{*}$ N.D. $=$ & mined & & & & & & \\
\hline
\end{tabular}


The concentration of the species in the $10 \mathrm{X} \mathrm{J}-13$ well water also increased with exposure time in these tests. Although the magnitudes of the increases were smaller than those observed for the $\mathrm{J}-13$ well water, the actual final concentrations of the species in the tests with the $10 \times \mathrm{J}-13$ well water were higher than those in the standard $J-13$ well water. As in the $J-13$ well water, maximum concentrations were observed for some species in the boiling $10 \mathrm{XJ}-13$ well water after a few months.

\subsubsection{Radiation Effects}

Relatively little research has been performed on the influence of the radiation field on the environment in the Tuff repository. On the other hand, a number of articles discuss, in general terms, the anticipated role of radiation in altering the repository environment while research on the effects of radiation on water and dilute aqueous solutions is much more extensive. As described by McCright-1984, the highest levels of radiation will occur on emplacement and the levels will begin to decay. The radiation of interest with regard to container corrosion will be gamma radiation. Interaction of the gamma radiation with either the container or the host rock is also expected to be minimal. Thus, the primary problem is the interaction of the gamma radiation field with the liquid and gas phases in the repository. Although most of the fission products responsible for gamma radiation decay rapidly, the repository environment will consist of air and water vapor during the time period when radiation levels will be high.

Radiolysis products expected in the moist-air system are not well established. Some experimental research regarding the temperature effects on radiolysis products has been performed by Van Konynenburg (1986) and others. Their research indicates that, above $135^{\circ} \mathrm{C}$, the dominant species are $\mathrm{NO}, \mathrm{N}_{2} \mathrm{O}$, and $\mathrm{O}_{3}$. Between $120^{\circ}$ and $135^{\circ} \mathrm{C}, \mathrm{NO}_{2}, \mathrm{~N}_{2} \mathrm{O}_{4}, \mathrm{H}_{2} \mathrm{O}$, and $\mathrm{O}_{3}$ are the dominant products, while below $120^{\circ} \mathrm{C}$, the most abundant products are $\mathrm{HNO}_{3}$ and $\mathrm{H}_{2} \mathrm{O}$ with small amounts of $\mathrm{O}_{3}$.

In liquid water at high radiation levels, small amounts of nitrates and nitrites will also be produced. However, the simultaneous presence of liquid water and high radiation fields are possible only intermittently during periods of liquid water movement through the repository.

Glass (1985 and 1986) reviewed the literature and performed electrochemical studies in irradiated $\mathrm{J}-13$ well water. These studies concluded that the primary effect of radiation of $\mathrm{J}-13$ well water is to produce the dominant oxidizing species $\mathrm{O}_{2}$ and $\mathrm{H}_{2} \mathrm{O}_{2}$ with smaller concentrations of $\mathrm{O}_{2}^{-}$and still smaller concentrations of $\mathrm{HO}_{2}$. Irradiation of water containing $\mathrm{CO}_{2}$ or $\mathrm{HCO}_{3}$ with $\mathrm{O}_{2}$ was found to produce carboxylic acids (formic and oxalic).

Studies focused on the effects of radiation on water and dilute aqueous solutions concluded that a host of transient radicals, ions, and stable molecular species is created by gamma radiation. Some of these species are as follows: $\mathrm{H} ;{ }^{-} \mathrm{OH}$, eaq, $\mathrm{H}_{3} \mathrm{O}^{+}, \mathrm{OH}^{-}, \mathrm{H}_{2}, \mathrm{H}_{2} \mathrm{O}_{2}, \mathrm{O}_{2}, \mathrm{O}_{2}^{-}$and $\mathrm{HO}_{2}$. While these species only consider the breakdown of the water molecule, many other species are generated by reactions with other species in the groundwater. 


\subsection{Simulated Environments}

\subsubsection{Simulated $\mathrm{J}-13$ Water}

Due to the difficulty in obtaining actual $\mathrm{J}-13$ well water required over the duration of the program, a simulated $\mathrm{J}-13$ well water was used. This simulated $\mathrm{J}-13$ well water was previously developed by Battelle Memorial Institute. The composition of the simulated J-13 well water is given in Table 2.3. The quality assurance procedure for preparing the simulated $\mathrm{J}-13$ well water directed that the $\mathrm{pH}$ of the solution be adjusted with hydrochloric acid $(\mathrm{HCl})$. The required amount of $\mathrm{HCl}$ addition was higher than that required in the initial development of the simulated J-13 well water, which was performed at Battelle, leading to slightly higher chloride levels than those given in Table 2.3.

This problem with the simulated $\mathrm{J}-13$ well water preparation is not considered to have a major impact on the results of this task for two reasons. First, comparison of results of cyclic potentiodynamic polarization (CPP) tests for actual and simulated $\mathrm{J}-13$ well water indicated no significant differences for either the two copper-base alloys or for Alloy 304L. Data for Alloy 825 were not available for comparison.

Secondly, the composition of the groundwater that comes in contact with the waste container is expected to be much more concentrated than that of the $\mathrm{J}-13$ well water as a result of thermal concentration. Thus, the composition of the simulated $\mathrm{J}-13$ well water is probably very dilute in comparison to water that will contact the actual container.

To reproduce and verify the polarization behavior observed by McCright (Figure 2.5), CPP curves were generated with the following test conditions: Actual J-13 well water, a scan rate of $3.6 \mathrm{~V} / \mathrm{hr}$, temperature of $80^{\circ} \mathrm{C}$, aerated conditions, and an initial exposure of $1-2$ hours prior to performing the CPP test. The actual $\mathrm{J}-13$ well water used in the NRC program was obtained from Oak Ridge National Laboratories.

The classical terms $E_{\text {pit }}$ and $E_{\text {prot }}$ were used for the pitting potential and the protection potential, respectively, for the $\mathrm{Fe}-\mathrm{Cr}-\mathrm{Ni}$ alloys. On the other hand, the terms $E_{b}$ and $E_{T p}$ were used to describe the breakdown potential and repassivation potential for the copper-base alloys. CPP tests performed under Task 2 of the program indicated that the copper-base alloys did not always exhibit classical pitting behavior and the distinction in the electrochemical terms was made to reflect this fact. The potentiodynamic polarization technique is discussed in more detailed in Appendix A.

The results of experiments performed for Alloy CDA 102 under the above conditions in simulated $\mathrm{J}-13$ well water and actual in $\mathrm{J}-13$ well water are shown in Figures 2.6 and 2.7, respectively. The curves are similar, with slight differences in the polarization parameters of $E_{b}, E_{p p}$, and $i_{c o r}$ (corrosion current). Repetition of these experiments verified the similarities. The above results produce two important findings that are critical to the remaining work performed in this project:

(1) Prepared solutions can reasonably simulate actual well waters extracted from the Tuff site, and 
Table 2.3 Chemical Composition Of Simulated Tuff Groundwater And J-13 Well Water From Yucca Mountain, Nevada (For Comparison).

\begin{tabular}{|c|c|c|}
\hline $\begin{array}{l}\text { Environmental } \\
\text { Variable }\end{array}$ & $\begin{array}{l}\mathrm{J}-13^{*} \\
\mathrm{ppm}\end{array}$ & $\begin{array}{c}\text { Simulated J-13ł } \\
\text { ppm }\end{array}$ \\
\hline $\mathrm{Na}^{+}$ & 44.0 & 46.0 \\
\hline $\mathrm{K}^{+}$ & 5.1 & 5.5 \\
\hline $\mathrm{Mg}^{2+}$ & 1.9 & 1.7 \\
\hline $\mathrm{Ca}^{2+}$ & 12.5 & 12.0 \\
\hline $\mathrm{SiO}_{2}$ & 58. & 64.2 \\
\hline$F^{-}$ & 2.2 & 1.7 \\
\hline $\mathrm{Cl}^{-}$ & 6.9 & 6.4 \\
\hline $\mathrm{HCO}_{3}^{-}$ & 125. & 121. \\
\hline $\mathrm{NO}_{3}^{-}$ & 9.6 & 12.4 \\
\hline $\mathrm{SO}_{4}{ }^{2-}$ & 18.7 & 19.2 \\
\hline $\mathrm{pH}$ & 7.6 & $7.0 \pm 0.2$ \\
\hline TDS & 291.5 & 290.3 \\
\hline
\end{tabular}




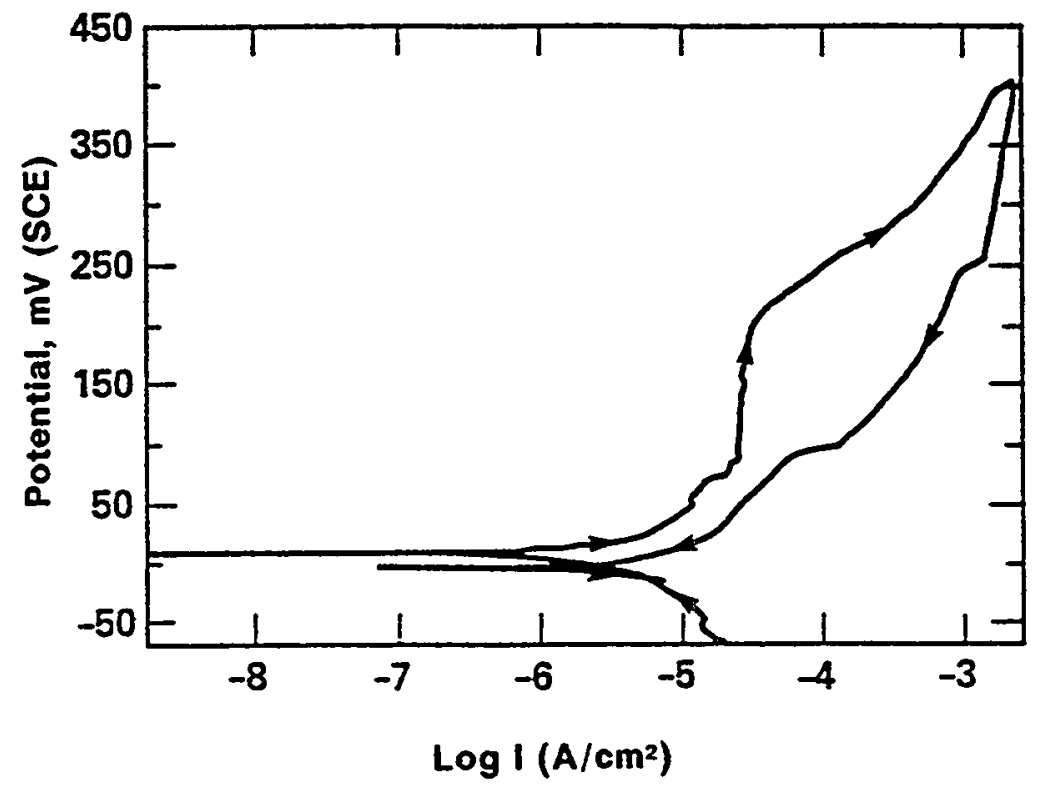

Figure 2.5 CPP Curve For Alloy CDA 102 In Actual J-13 Well Water At $80^{\circ} \mathrm{C}$ (Scan Rate: 1 $\mathrm{mV} / \mathrm{s}$ ) Produced By McCright (McCright-1985). 


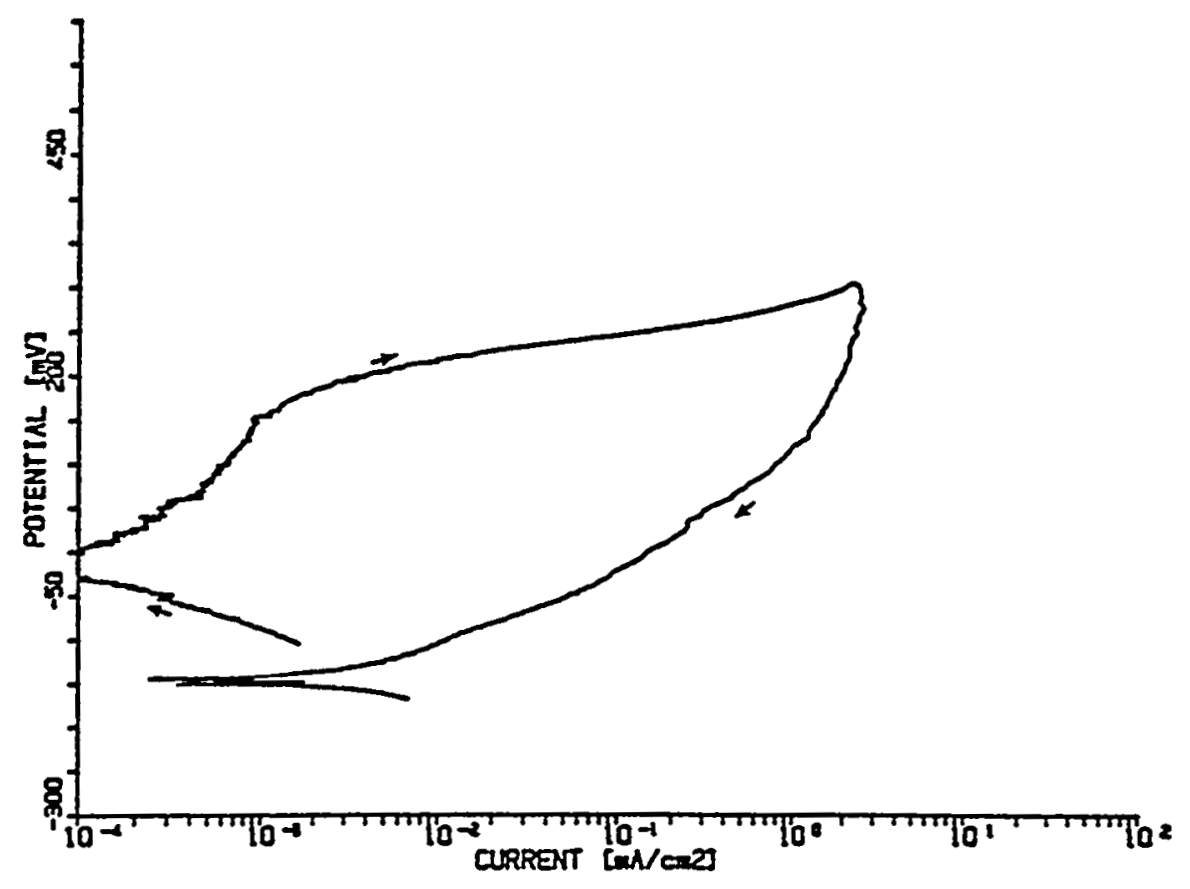

Figure 2.6 Polarization Curve For Alloy CDA 102 in Simulated J-13 Well Water At $80^{\circ} \mathrm{C}$ Following A One Hour Initial Exposure (Beavers-1988).

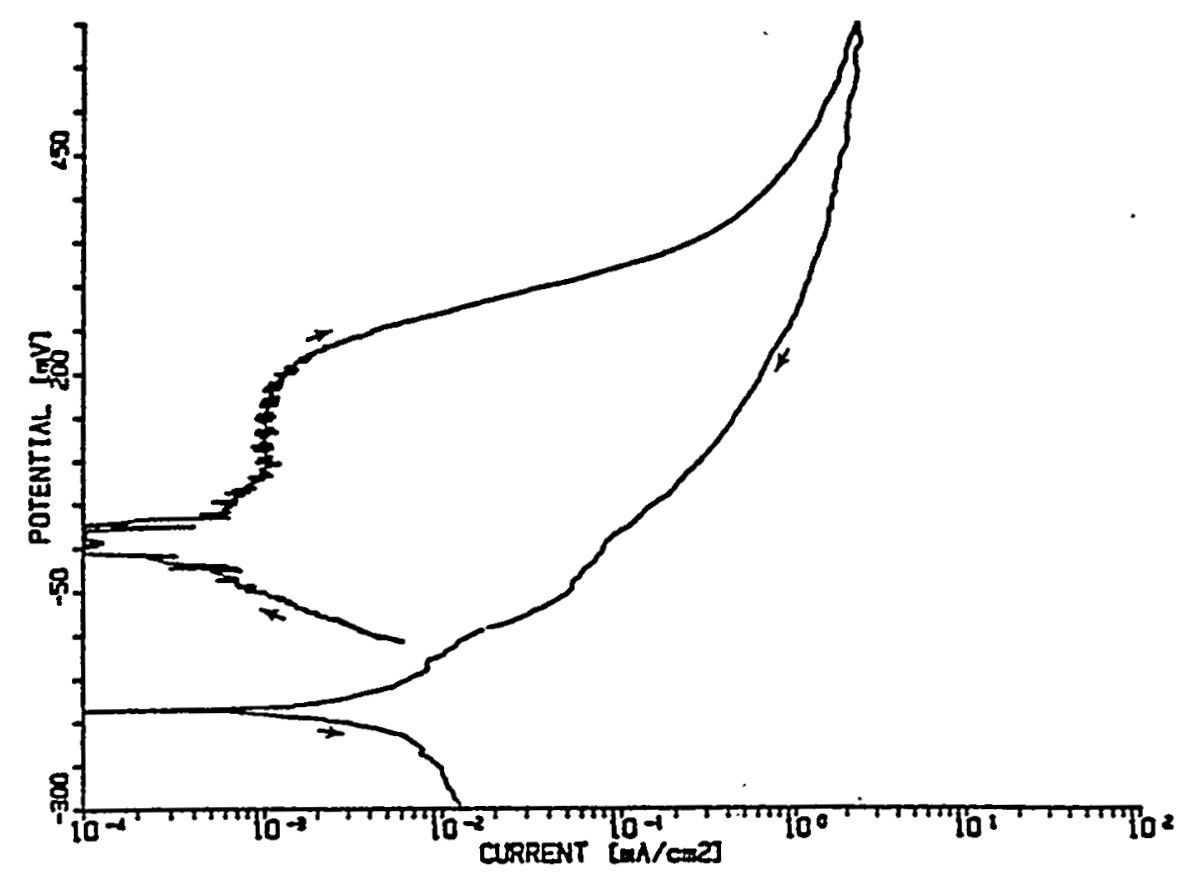

Figure 2.7 Polarization Curve For Alloy CDA 102 In Actual J-13 Well Water At $80^{\circ} \mathrm{C}$ Following A One Hour Initlal Exposure (Beavers-1988). 
(2) The experimental procedures used for the NRC project are capable of reproducing the polarization behavior observed at Lawrence Livermore National Laboratory under similar test conditions.

There are two test conditions that are being employed in the NRC program which are different than those used for the curves discussed above: (1) The period of exposure to the environment is $15-20$ hours compared to $1-2$ hours and, (2) The scan rate is $0.6 \mathrm{~V} / \mathrm{hr}$ compared to $3.6 \mathrm{~V} / \mathrm{hr}$. Both the longer exposure period and slower scan rate help insure nearer steady-state conditions. This, in turn, improves reproducibility and provides better estimates of corrosion rates and freecorrosion potentials. Tests were performed to examine the effects of these two differences in procedures on the polarization behavior. In the first test, the scan rate was left unchanged at 3.6 $\mathrm{V} / \mathrm{hr}$ and a longer exposure time prior to performing the CPP test was permitted. Figures 2.8 and 2.9 show the polarization curves for CDA 102 copper for simulated and actual J-13 well water, respectively, with the longer initial exposure times. Comparisons to Figures 2.6 and 2.7 show that slight changes in the corrosion parameters occurred. The polarization behavior in Figures 2.8 and 2.9 should represent nearer steady-state initial test conditions.

The second condition which was varied from the curves shown in Figures 2.6 and 2.7 is scan rate. Figure 2.10 shows a polarization curve for Alloy CDA 102 in simulated J-13 well water with an initial exposure period of sixteen hours, a scan rate of $0.6 \mathrm{~V} / \mathrm{hr}$, and a temperature of $90^{\circ} \mathrm{C}$ instead of $80^{\circ} \mathrm{C}$. The $90^{\circ} \mathrm{C}$ temperature was selected to coincide with the matrix of tests. These conditions are identical to those for Figure 2.8 except that the $0.6 \mathrm{~V} / \mathrm{hr}$ scan rate is six times slower than for the curve shown in Figure 2.8 and the temperature is 10 degrees higher. Figures 2.11 - 2.13 show the polarization curves for Alloy CDA 715, Alloy 304L and Alloy 825 in simulated $\mathrm{J}-13$ well water under the same conditions as for Figure 2.10. (The compositions of the candidate alloys are given in Appendix C.)

Comparing the behavior seen in Figure 2.10 (slow scan rate) to Figure 2.8 (fast scan rate), the only significant difference is in the value of the breakdown potential, $E_{b}$. The much more negative value for $E_{b}$ for the slower scan rate is not unusual since pitting has some initiation time associated with it and this behavior has been seen in other alloy-environmental combinations. It should be noted that the increase in temperature also would produce a similar trend. The behavior for the slower scan rate is nearer steady-state conditions and predicts actual field situations more closely. Therefore, all subsequent CPP testing used a $0.6 \mathrm{~V} / \mathrm{hr}$ scan rate and an initial exposure time of $15-20$ hours prior to performing the CPP test.

\subsubsection{Selected Task 3 Environments}

Two environments, in addition to simulated $\mathrm{J}-13$ well water, were evaluated in Task 3 of this program. These two selected environments, Solution No. 20 and Solution No. 7, were chosen based upon their behavior during cyclic potentiodynamic polarization studies performed in Task 2 of the overall program. In Task 2, a statistical experimental design approach was used to evaluate the influence of environmental variables on the cyclic potentiodynamic polarization behavior of the candidate container materials. A total of 33 test solutions was studied to represent variation in the repository environment due to radiation effects and boiling near the canister. Further details of the Task 2 studies are given in Appendix B. 


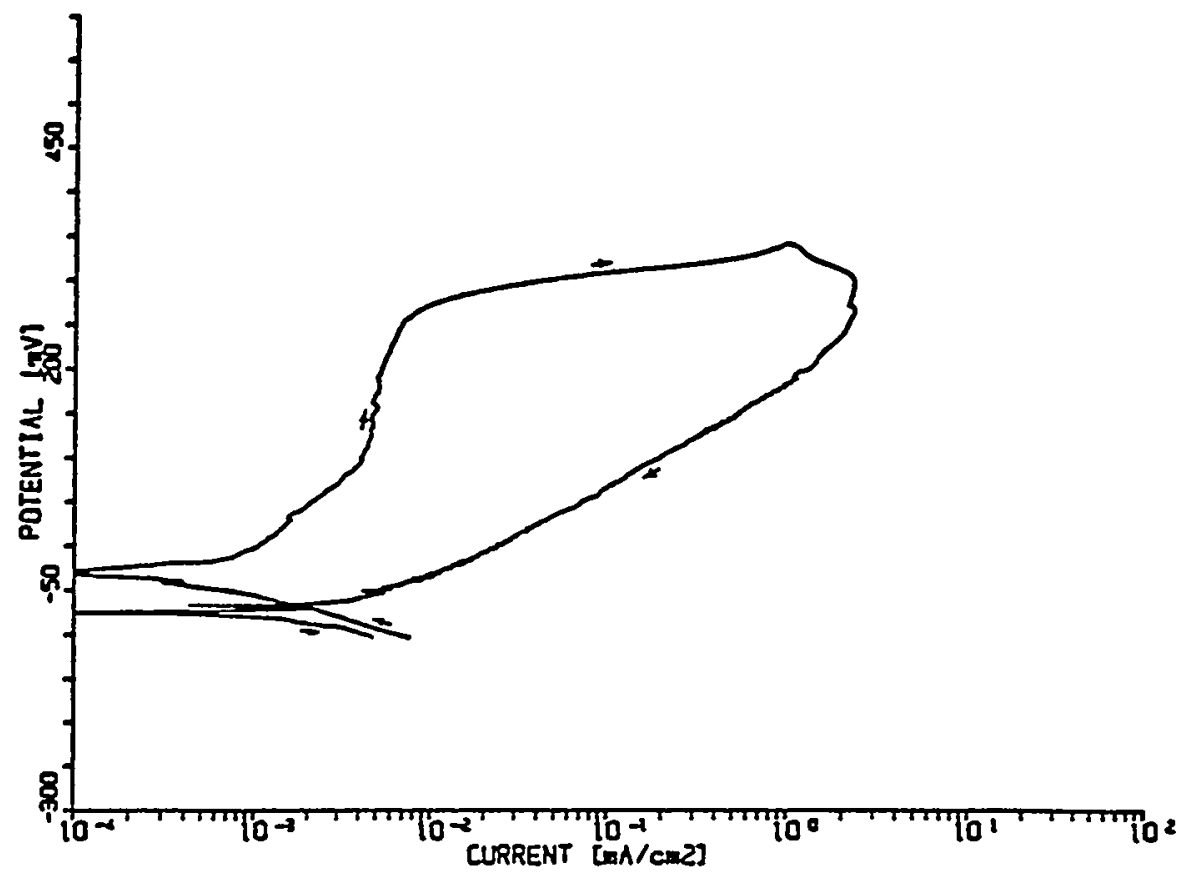

Figure 2.8 Polarization Curve For Alloy CDA 102 In Simulated J-13 Well Water At $80^{\circ} \mathrm{C}$ Following A Fifteen Hour Initial Exposure (Beavers-1988).

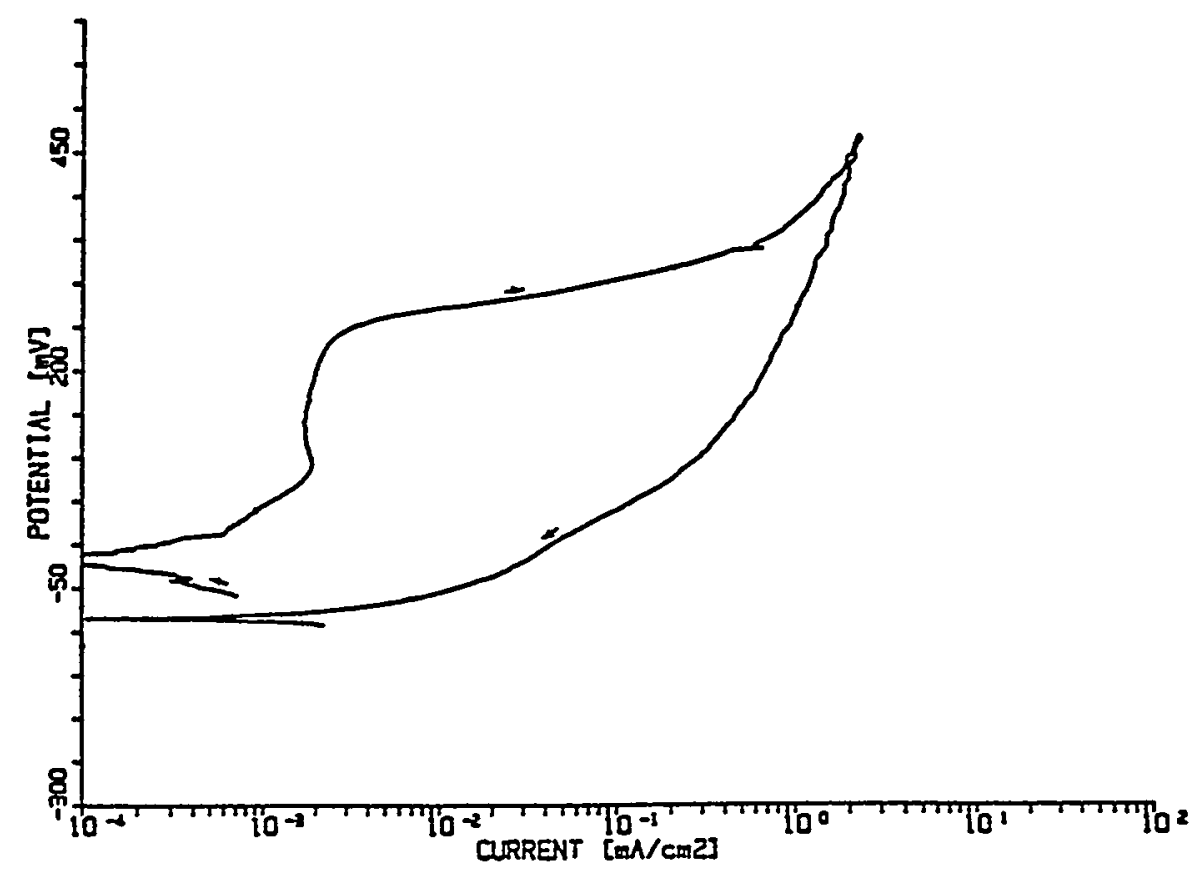

Figure 2.9 Polarization Curve For Alloy CDA 102 in Actual J-13 Well Water At $80^{\circ} \mathrm{C}$ Following A Fifteen Hour Initial Exposure (Beavers-1988). 


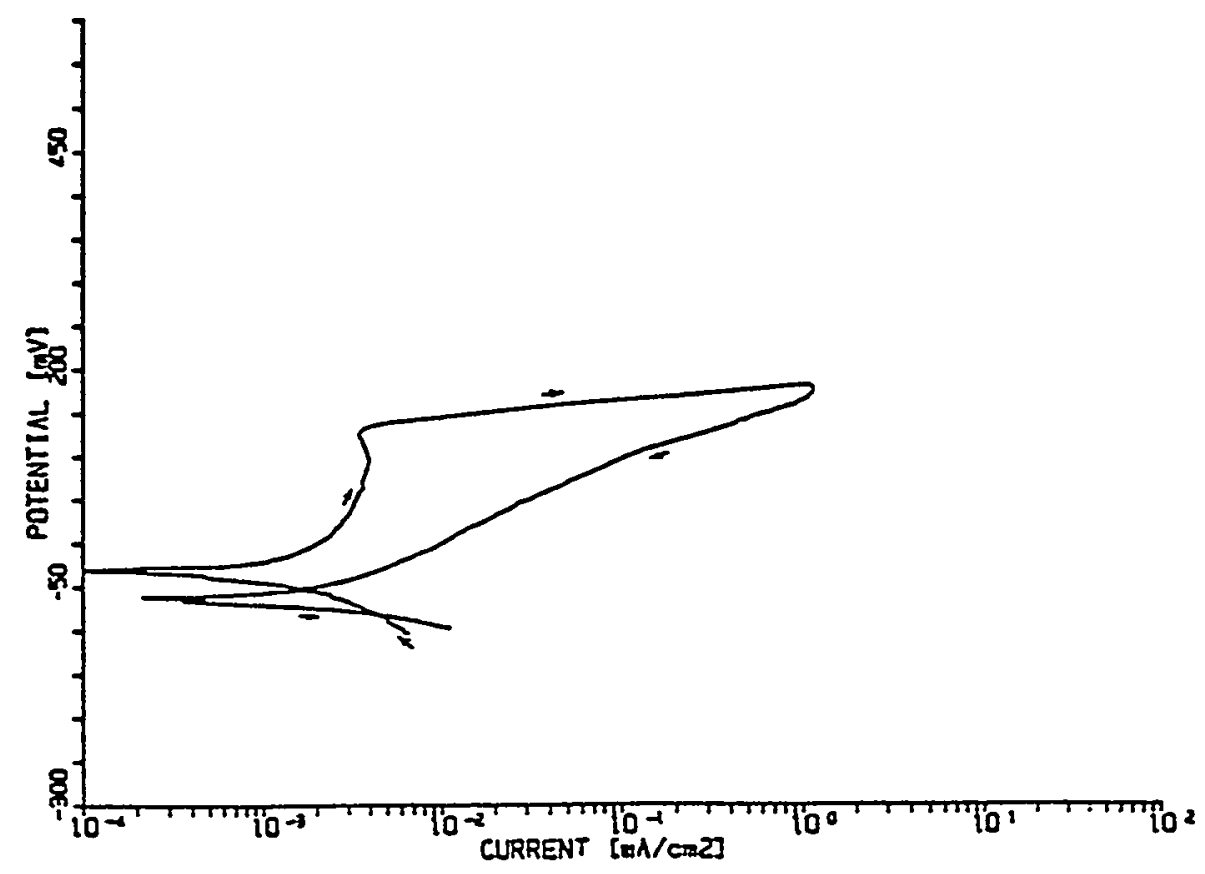

Figure 2.10 Polarization Curve For Alloy CDA 102 in Simulated J-13 Well Water At $90^{\circ} \mathrm{C}$ Run At A Scan Rate of $0.6 \mathrm{~V} / \mathrm{hr}$ (Beavers-1988).

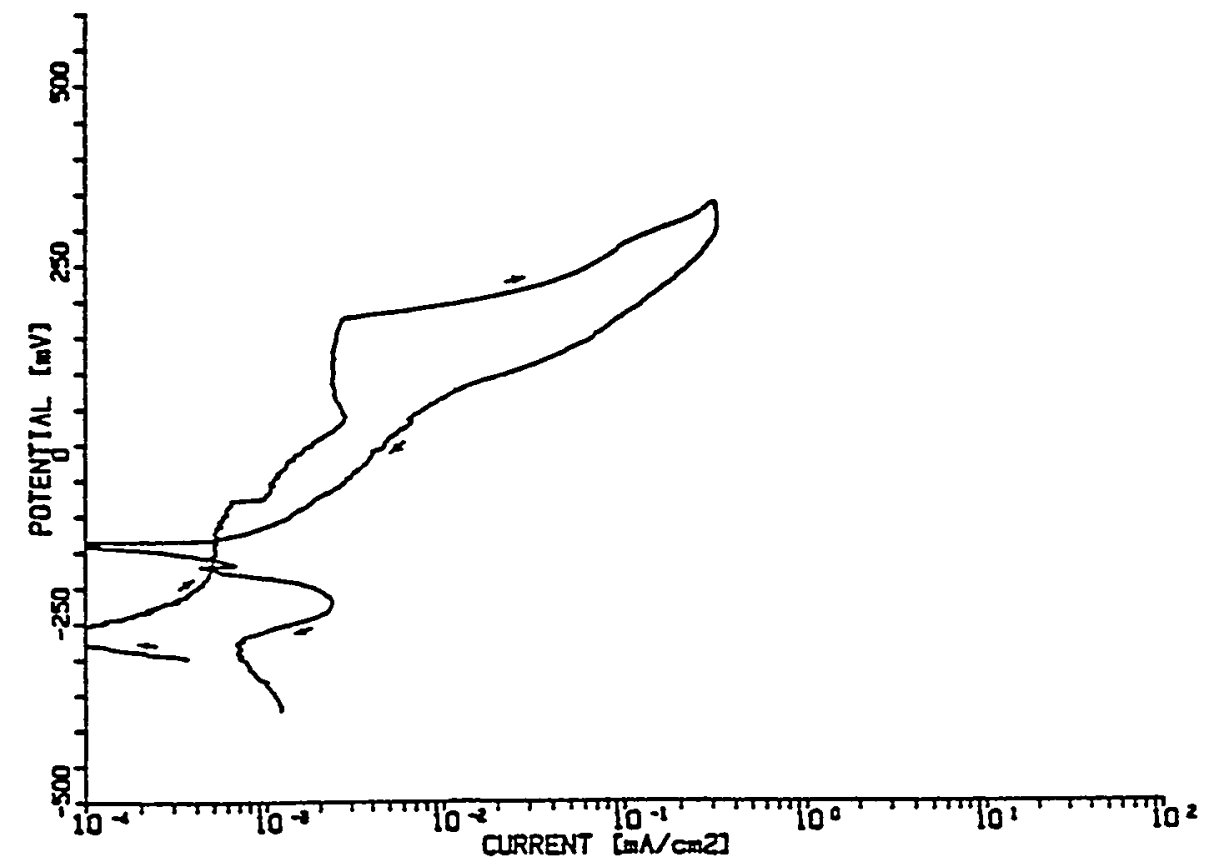

Figure 2.11 Polarization Curve For Alloy CDA 715 in Simulated J-13 Well Water At $90^{\circ} \mathrm{C}$ Run At A Scan Rate Of $0.6 \mathrm{~V} / \mathrm{hr}$ (Beavers-1988). 


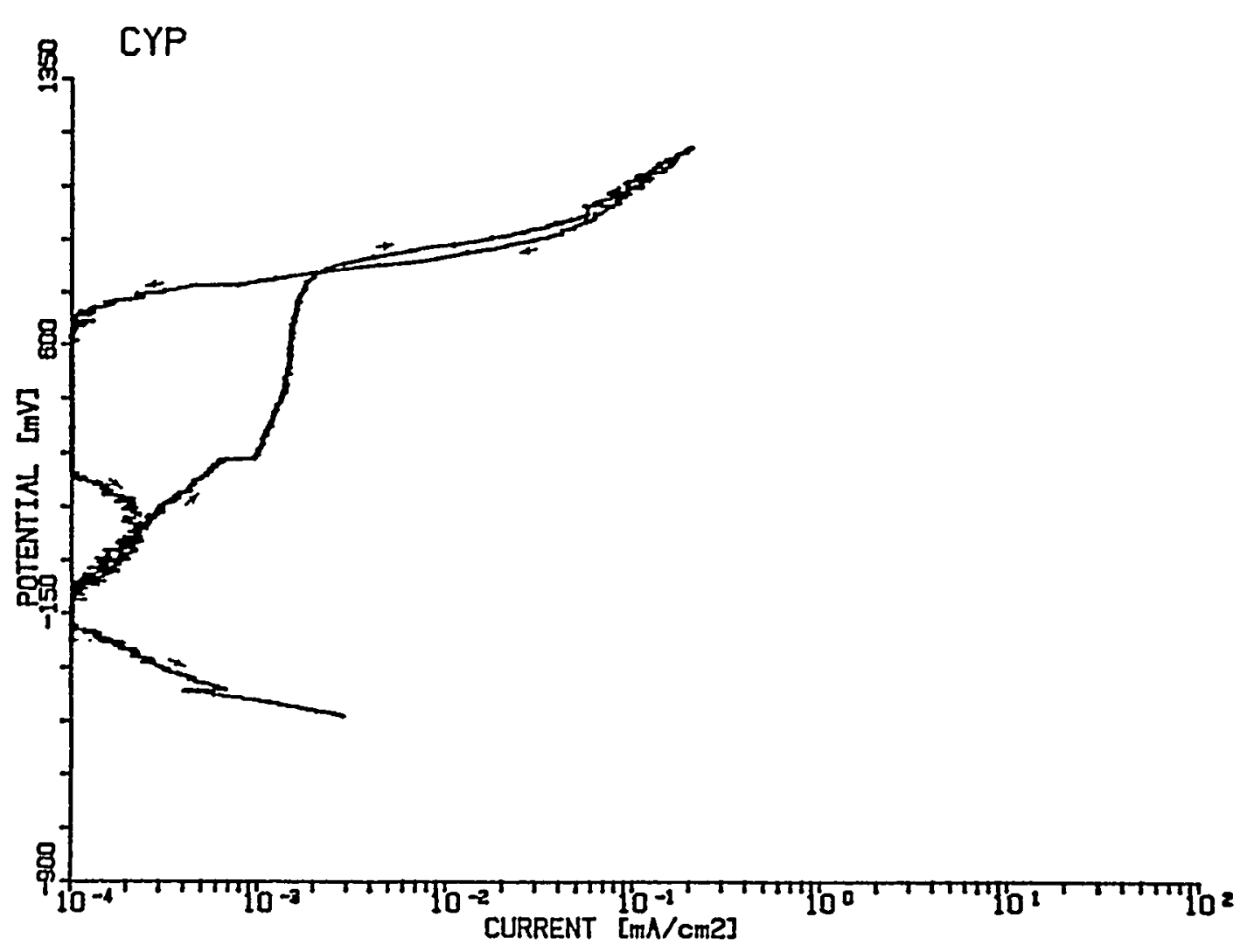

Figure 2.12 Polarization Curve For Alloy $304 \mathrm{~L}$ In Simulated J-13 Well Water At $90^{\circ} \mathrm{C}$ Run At A Scan Rate Of $0.6 \mathrm{~V} / \mathrm{hr}$ (Beavers-1989).

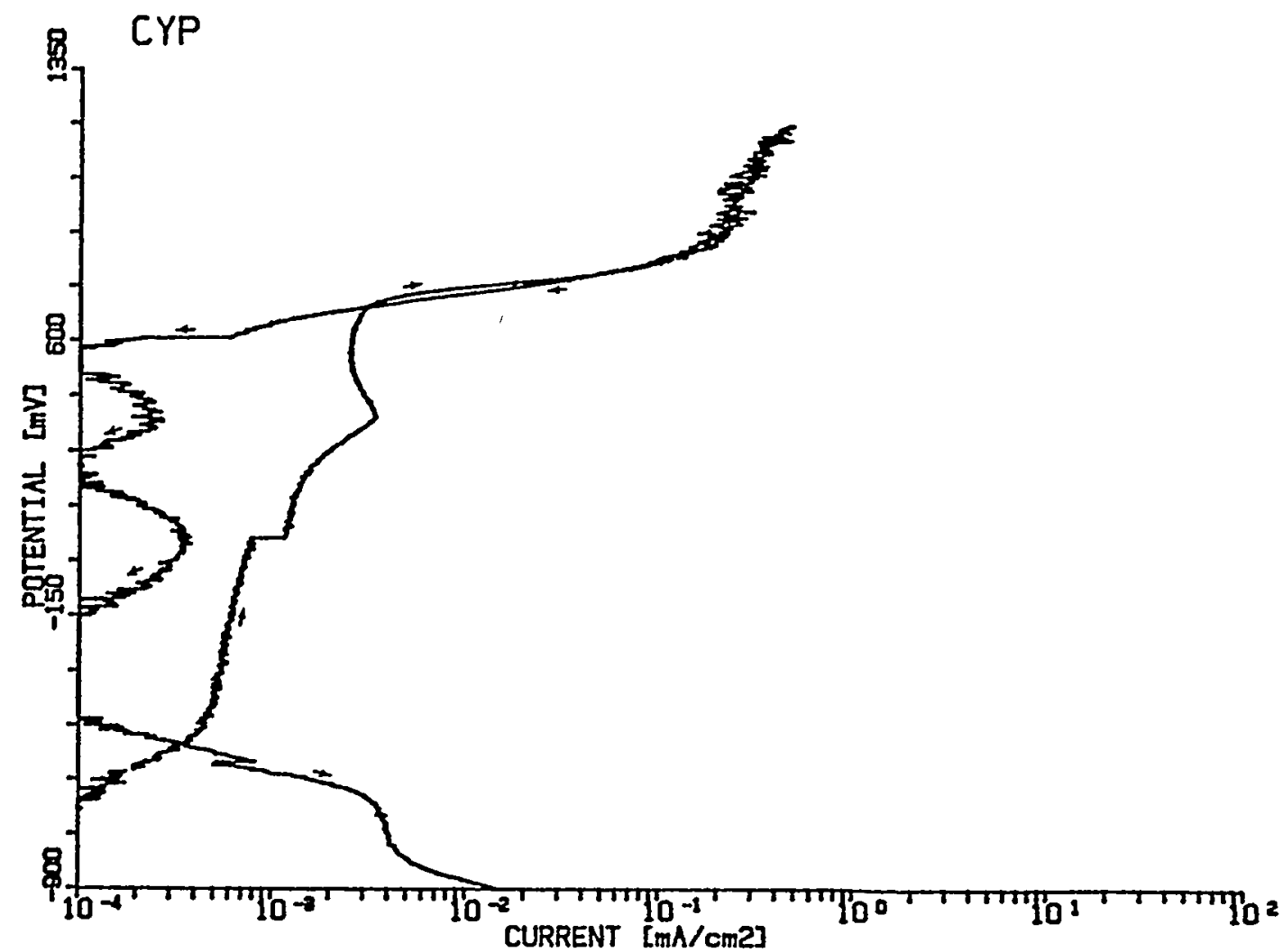

Figure 2.13 Polarization Curve For Alloy 825 In Simulated J-13 Well Water At $90^{\circ} \mathrm{C}$ Run At A Scan Rate Of $0.6 \mathrm{~V} / \mathrm{hr}$ (Beavers-1989). 
Each of the Fe-Cr-Ni alloys, Alloy 304L and Alloy 825, was evaluated in Solution No. 20. The copper-base alloys, Alloy CDA 102 and Alloy CDA 715, were both evaluated in Solution No. 7. The compositions of each of these solutions, as compared with $\mathrm{J}-13$ well water, are shown in Table 2.4. Solution No. 20 was found to be a pitting environment for the $\mathrm{Fe}-\mathrm{Cr}-\mathrm{Ni}$ alloys at $90^{\circ} \mathrm{C}$ as evidenced by the large hysteresis loop on the polarization curves shown in Figures 2.14 and 2.15. Solution No. 7 was found to be an active corrosion environment for the copper-base alloys at $90^{\circ} \mathrm{C}$. The polarization curves for these alloys are given in Figures 2.16 and 2.17.

A summary of the polarization parameters for the selected alloys in simulated $\mathrm{J}-13$ well water, Solution No. 20, and Solution No. 7 is given in Table 2.5. The pitting potential $\left(E_{\text {pit }}\right)$ and the repassivation or protection potential $\left(E_{p p}\right)$ become important in the analysis of the Task 3 immersion data and aid in explaining the behavior of these alloys in the selected environments. 
Table 2.4 Composition Of $\mathrm{J}-13$ Well Water And Selected Solutions From The Experimental Matrix.

\begin{tabular}{|c|c|c|c|c|}
\hline $\begin{array}{l}\text { Environmental } \\
\text { Species }\end{array}$ & $\begin{array}{c}\mathrm{J}-13 \\
\text { Well Water } \\
\mathrm{mg} / \mathrm{l}\end{array}$ & $\begin{array}{c}\text { Simulated } \\
\mathrm{J}-13 \\
\text { Well Water } \\
\mathrm{mg} /\end{array}$ & $\begin{array}{c}\text { Solution } \\
\text { No. } 20 \\
\mathrm{mg} / \mathrm{l}\end{array}$ & $\begin{array}{c}\text { Solution } \\
\text { No. } 7 \\
\mathrm{mg} / \mathrm{l}\end{array}$ \\
\hline $\mathrm{pH}$ & 7.6 & $7.0 \pm 0.2$ & 10.0 & 5.0 \\
\hline $\mathrm{SiO}_{2}$ & 58 & 64.2 & 2.2 & 215 \\
\hline $\mathrm{HCO}_{3}^{-}$ & 125 & 121 & 0.4 & 0.4 \\
\hline$F^{-}$ & 2.2 & 1.7 & 200 & 0.04 \\
\hline $\mathrm{Cl}^{-}$ & 6.9 & 6.4 & 1000 & 1000 \\
\hline $\mathrm{NO}_{3}^{-}$ & 9.6 & 12.4 & 0.2 & 0.2 \\
\hline $\mathrm{SO}_{4}^{2-}$ & 18.7 & 19.2 & - & $\cdot$ \\
\hline $\mathrm{NO}_{2}^{-}$ & - & - & 200 & 0 \\
\hline $\mathrm{H}_{2} \mathrm{O}_{2}$ & - & - & 0.0 & 0 \\
\hline $\mathrm{Al}^{3+}$ & 0.012 & - & 0.8 & 0.0004 \\
\hline $\mathrm{Fe}^{2+}$ & 0.006 & - & 0.0 & 0.0 \\
\hline $\mathrm{Ca}^{2+}$ & 12.5 & 12.0 & 0.8 & 0.8 \\
\hline $\mathrm{Mg}^{2+}$ & 1.9 & 1.7 & 0.8 & 0.8 \\
\hline $\mathrm{K}^{+}$ & 5.1 & 5.5 & 408 & 0.08 \\
\hline $\mathrm{Na}^{+}$ & 44 & 46 & • & • \\
\hline $\mathrm{PO}_{4}{ }^{3-}$ & 0.12 & - & 2.0 & 2.0 \\
\hline Oxalic Acid & - & - & 0.0 & 172 \\
\hline
\end{tabular}

${ }^{*} \mathrm{Na}^{+}$and $\mathrm{SO}_{4}{ }^{2-}$ were used to balance the composition. 


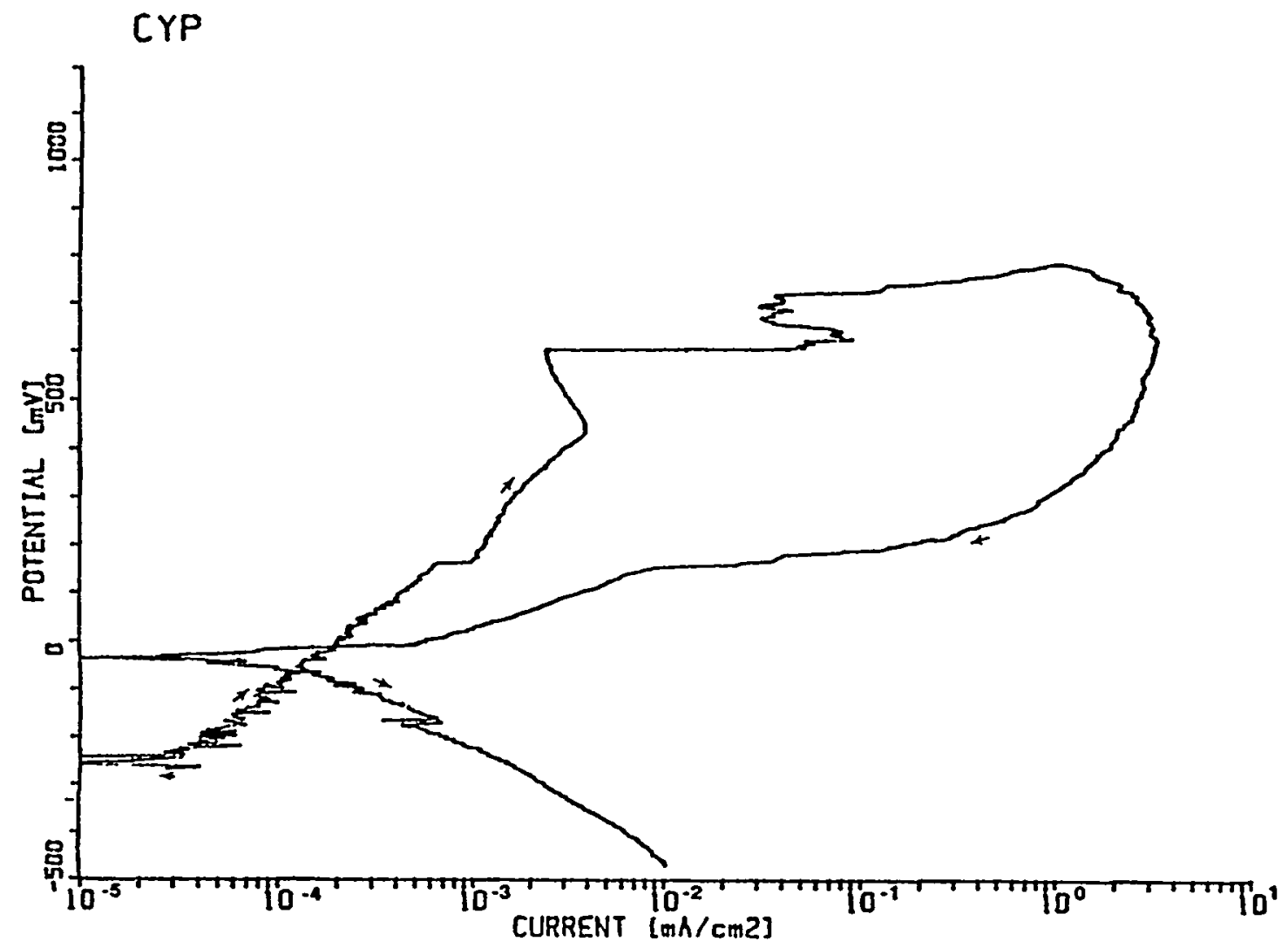

Figure 2.14 Polarization Curve For Alloy 825 in Test Solution No. 20 At $90^{\circ} \mathrm{C}$ (Beavers-1990).

CYP

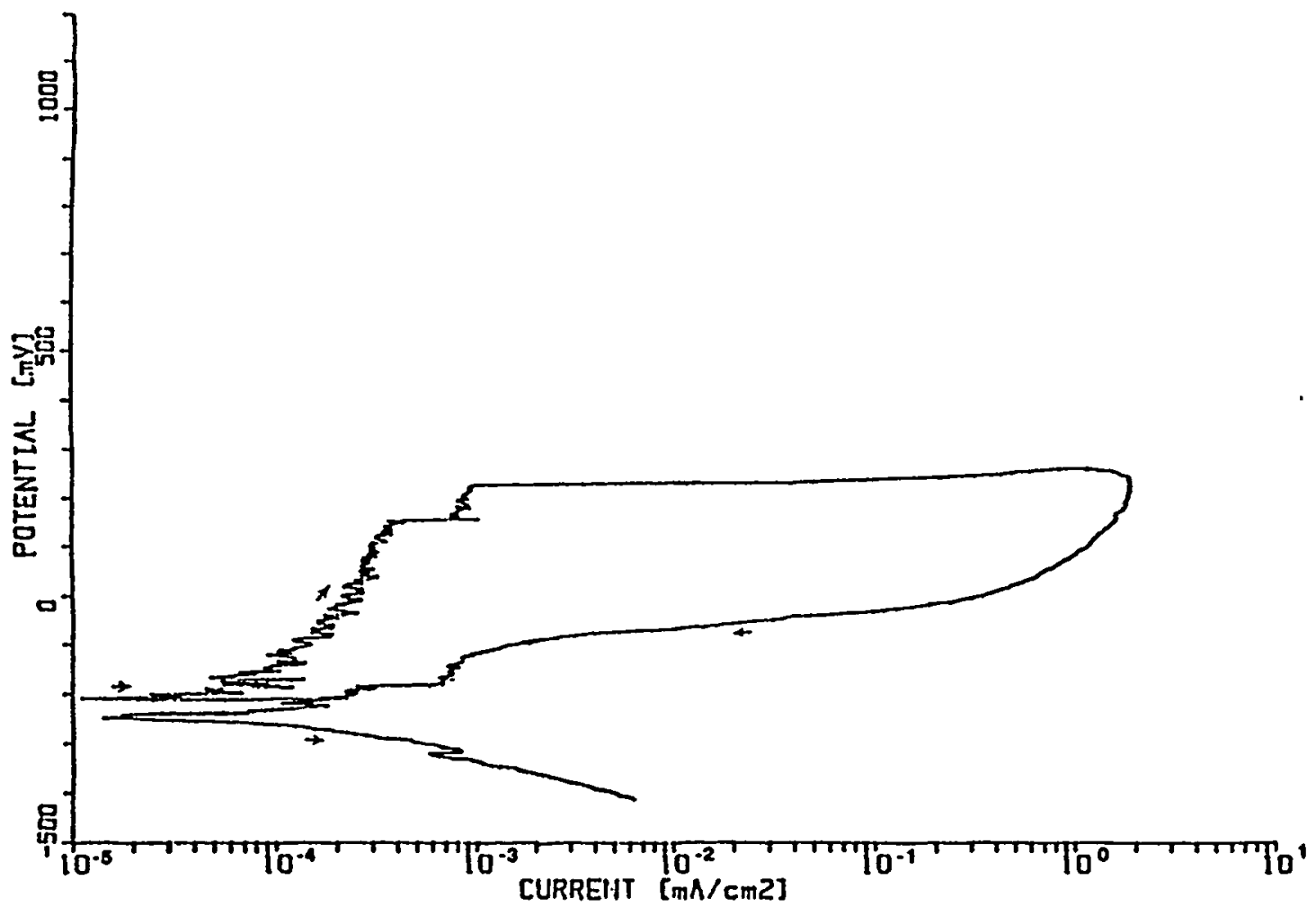

Figure 2.15 Polarization Curve For Alloy 304L In Test Solution No. 20 At $90^{\circ} \mathrm{C}$ (Beavers-1990). 
CYP

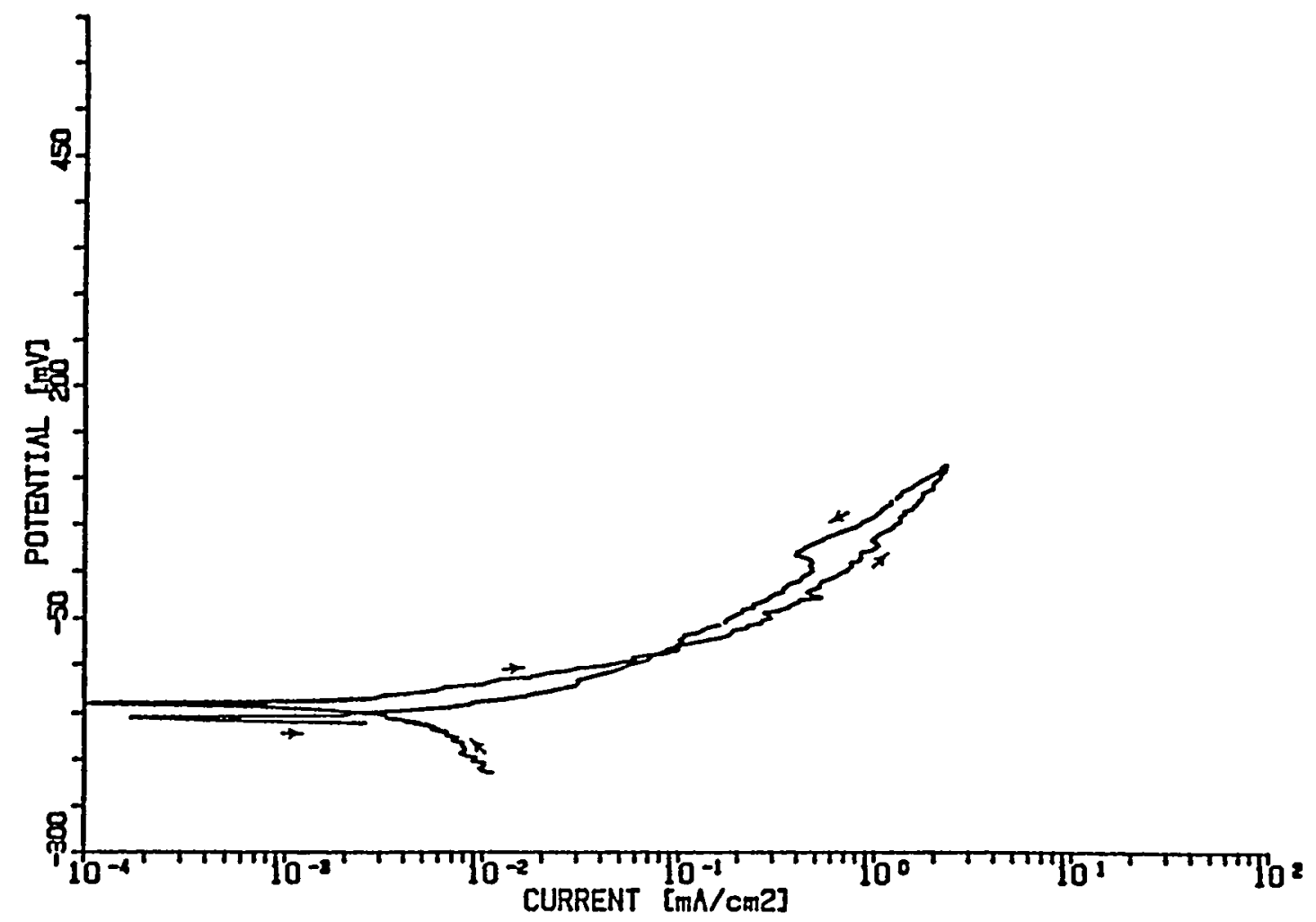

Figure 2.16 Polarization Curve For Alloy CDA 102 in Test Solution No. 7 At $90^{\circ} \mathrm{C}$ (Beavers1990a).

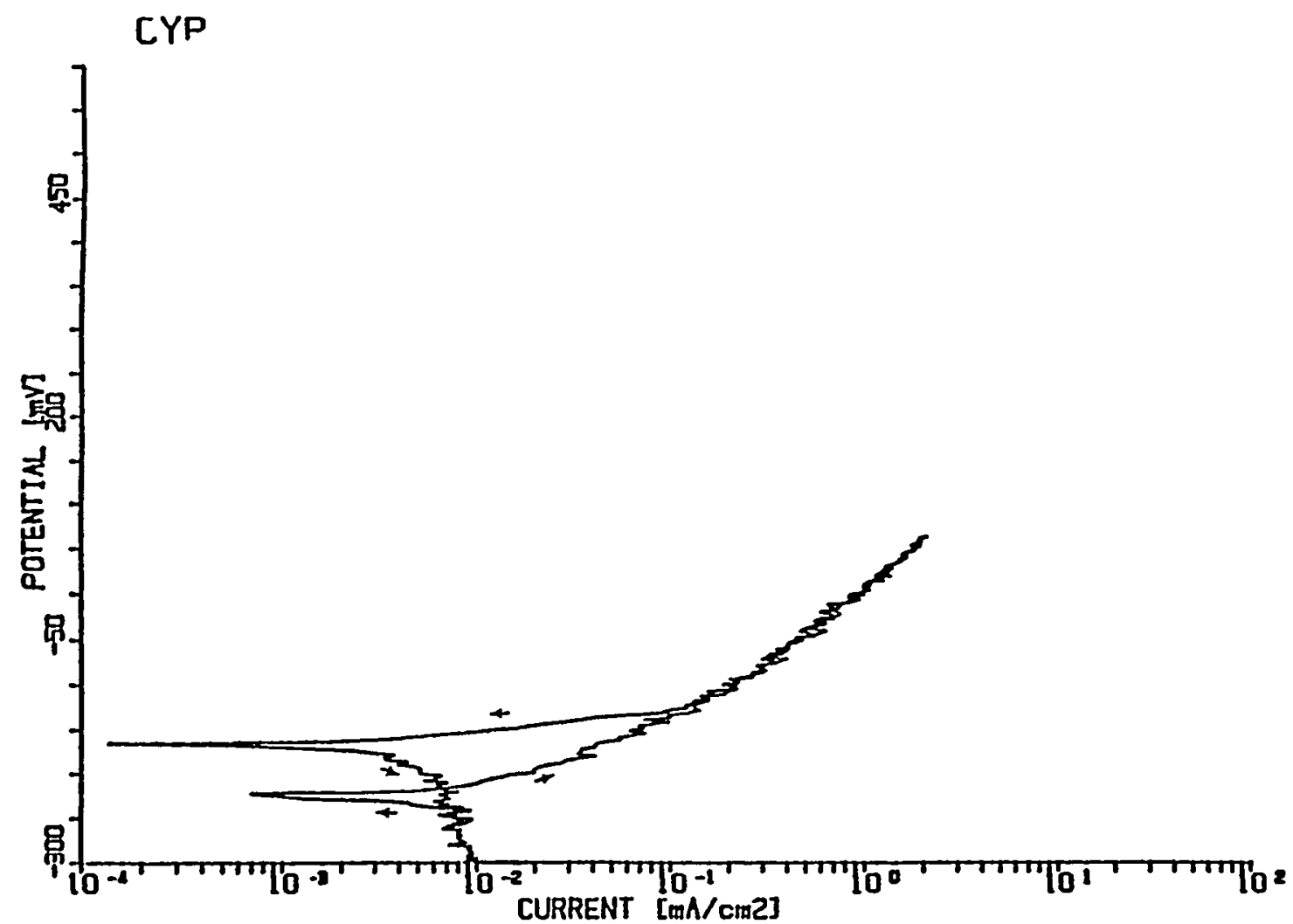

Figure 2.17 Polarization Curve For Alloy CDA 715 In Test Solution No. 7 At $90^{\circ} \mathrm{C}$ (Beavers1989a). 
Table 2.5 Summary Of The Polarization Parameters For Selected Alloys In Simulated J-13 Well Water, Solution No. 20 And Solution No. 7 At $90^{\circ} \mathrm{C}$.

\begin{tabular}{|c|c|c|c|c|c|c|c|}
\hline $\begin{array}{l}\text { Test } \\
\text { Solution }\end{array}$ & Alloy & $\begin{array}{l}\text { Solution } \\
\text { Temp } \\
{ }^{\circ} \mathrm{C}\end{array}$ & $\begin{array}{c}E_{\infty \alpha} \\
V, S C E\end{array}$ & $\begin{array}{l}\mathrm{i}_{\infty} \\
\mathrm{A} / \mathrm{cm}^{2} \\
\times 10^{-6}\end{array}$ & $\begin{array}{c}E_{p \mathrm{pi}} / E_{\mathrm{b}} \\
V, S C E\end{array}$ & $\begin{array}{l}E_{p r o t} J E_{T p} \\
V, S C E\end{array}$ & Comments \\
\hline$J 13^{*}$ & $304 \mathrm{~L}$ & 90 & -0.125 & 0.12 & +0.800 & +0.800 & No pitting. \\
\hline$\sqrt{ } 13^{*}$ & 1825 & 90 & -0.650 & 0.08 & +0.700 & +0.700 & No pitting. \\
\hline$J 13^{*}$ & CDA 102 & 90 & -0.030 & 2.00 & +0.140 & -0.035 & $\begin{array}{l}\text { Local changes in } \\
\text { oxide. }\end{array}$ \\
\hline$J 13^{*}$ & CDA 715 & 90 & -0.265 & 0.41 & +0.180 & +0.080 & $\begin{array}{l}\text { Local changes in } \\
\text { oxide, local active } \\
\text { attack with a few } \\
\text { shallow pits. }\end{array}$ \\
\hline 20 & $304 \mathrm{~L}$ & 90 & -0.205 & 0.13 & +0.210 & -0.110 & Pitting. \\
\hline 20 & 1825 & 90 & -0.250 & 0.05 & +0.610 & +0.150 & Pitting. \\
\hline 7 & CDA 102 & 90 & -0.140 & 6.6 & -0.140 & -0.140 & $\begin{array}{l}\text { No pitting, local oxide } \\
\text { growth. }\end{array}$ \\
\hline 7 & CDA 715 & 90 & -0.150 & 23 & -0.150 & -0.200 & $\begin{array}{l}\text { No pitting; active } \\
\text { areas. }\end{array}$ \\
\hline
\end{tabular}

*Simulated J-13 Well Water 


\section{EXPERIMENTAL APPROACH}

Testing was performed at $90^{\circ} \mathrm{C}$ in simulated $\mathrm{J}-13$ well water and in two other environments (Solution No. 20 and Solution No. 7). Each of the candidate alloys was evaluated in the simulated J-13 well water. The Fe-Cr-Ni alloys were evaluated in Solution No. 20, a solution that was found to be an active pitting environment for these alloys. The copper-base alloys were evaluated in Solution No. 7, a solution that was found to be an active corrosion environment for these alloys. These solutions were selected from the experimental test matrix from Task 2 of the program. They represent single points within a 15 dimension factor space which was designed to represent possible changes in the repository environment as a result of boiling and irradiation.

The overall test matrix consisted of four alloys, three environments, and four test conditions (liquid phase, vapor phase, vapor-liquid interface, and alternate immersion). Table 3.1 shows the specimen types, exposure conditions and exposure times for each of the vessels. As shown in the table, constant strain (U-bend) specimens were included in the sample matrix to evaluate the susceptibility to stress-corrosion cracking after selected hours of exposure. The exposure tests were performed in four-liter glass resin kettles. These vessels, as shown in Figure 3.1, have a removable lid, four ground glass access ports in the lid, electrical resistance heating mantles, and glass Leibig condensers. Initially, two vessels were needed for each alloy-environment to evaluate both creviced and uncreviced specimens. Later testing utilized only one vessel, and evaluated only creviced specimens as data suggested that the presence or absence of the crevices did not measurably affect the weight losses. With the exception of the vapor-liquid interface specimens and electrochemical monitors, all specimens were exposed in triplicate and designed so that individual "racks" of specimens could be removed and evaluated at three different exposure times to assess the time dependence of the corrosion process for periods up to 2000 hours.

Test specimens $(2.54 \mathrm{~cm} \times 2.54 \mathrm{~cm} \times 0.32 \mathrm{~cm}$ ) were mounted on Alloy $\mathrm{C} 276$ threaded rods and electrically isolated from the rods with tetrafluoroethylene (TFE) washers. Serrated TFE washers were clamped to the creviced specimens to create a TFE-metal crevice. The instantaneous corrosion rate as a function of time was measured periodically by means of a three-electrode polarization resistance (PR) technique, utilizing the machined rod as the working electrode, one of the Alloy C276 supports as a counter electrode and a glass Luggin probe with an SCE electrode. The Luggin probe entered the cell vertically and was filled with the test electrolyte during the PR measurements.

Accelerated corrosion at the vapor-liquid interface was evaluated by means of a precision-machined rod which provided an accurate diameter over the length of the rod. The rod was immersed approximately $4 \mathrm{~cm}$ with the remaining length (approximately $20 \mathrm{~cm}$ ) exposed to the vapor phase. After exposure, measurement of the loss in diameter provided the rate of penetration at the interface as well as in the vapor and liquid phases. The rod was also examined metallographically following exposure for evidence of localized attack.

The instantaneous corrosion rate in the vapor phase was evaluated by means of vapor-phase corrosion monitors. These monitors consisted of multiple thin plates of the candidate alloy separated by thin insulation. Alternate plates were electrically connected. The plate assembly was mounted in epoxy and one edge was ground and polished to expose the plate sandwich. 
Table 3.1 Summary Of Specimens Used In The Task 3 Immersions Studies.

\begin{tabular}{|c|c|c|c|c|c|c|c|}
\hline Vessel & Conditions & $\begin{array}{l}\text { Specimen } \\
\text { Type }\end{array}$ & $\begin{array}{l}\text { Number of } \\
\text { Specimens }\end{array}$ & Exposure & Time & Hours & $\begin{array}{c}\text { Total } \\
\text { Number } \\
\text { Of } \\
\text { Specimens }\end{array}$ \\
\hline 1 & Vapor & Creviced & 3 & 500 & 1000 & 2000 & 9 \\
\hline 1 & Vapor & Uncreviced & 3 & 500 & 1000 & 2000 & 9 \\
\hline 1 & Liquid & Creviced & 3 & 500 & 1000 & 2000 & 9 \\
\hline 1 & Liquid & Uncreviced & 3 & 500 & 1000 & 2000 & 9 \\
\hline 1 & V/L Interface & Machined Rod & 1 & & & 2000 & 1 \\
\hline 1 & Vapor & $\begin{array}{l}\text { Electrochemical } \\
\text { Monitor }\end{array}$ & 1 & & & 2000 & 1 \\
\hline 2 & Vapor & U-Bend & 3 & 500 & 1000 & 2000 & 9 \\
\hline 2 & Liquid & U-Bend & 3 & 500 & 1000 & 2000 & 9 \\
\hline 2 & Alt Immersion & Creviced & 3 & & & 2000 & 3 \\
\hline 2 & Alt Immersion & Uncreviced & 3 & & & 2000 & 3 \\
\hline 2 & Alt Immersion & U-Bend & 3 & & & 2000 & 3 \\
\hline
\end{tabular}




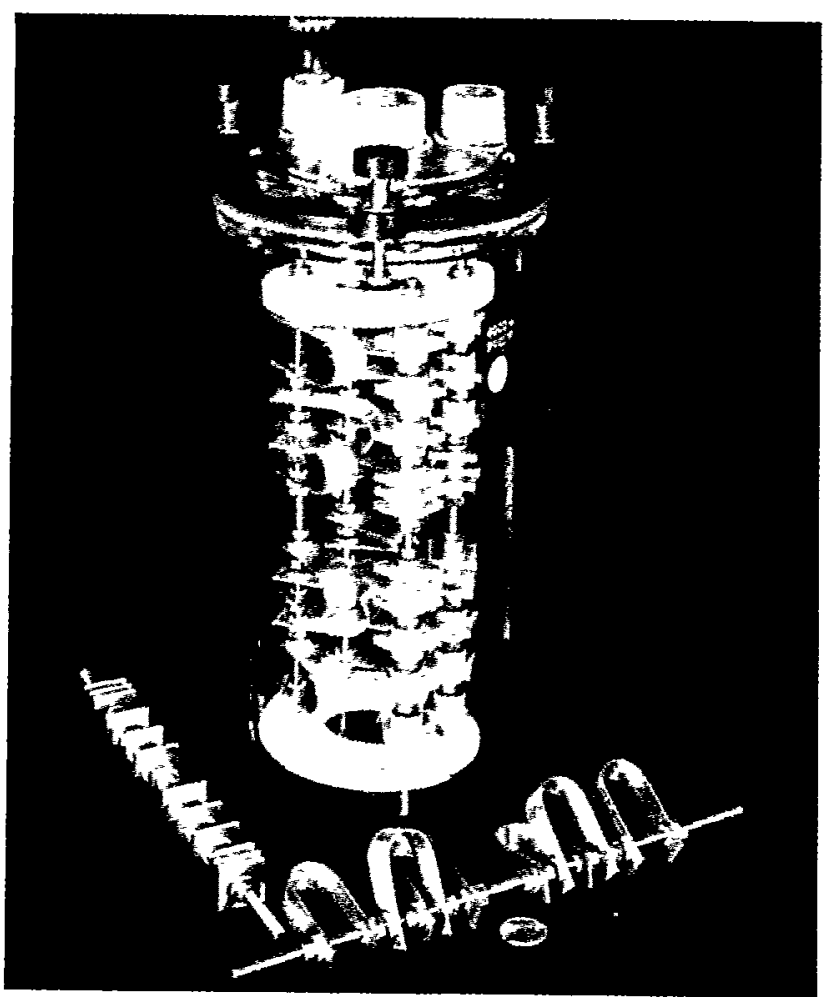

Figure 3.1 Glass Resin Kettles Used In The Task 3 Immersion Studies. 
The polished edge was then exposed to the corrosive vapor-phase environment. The polarization resistance of the material was monitored as a function of time by means of the two-electrode technique, using alternating electrodes.

In the actual PR measurements, the specimen potential was scanned between $-20 \mathrm{mV}$ and +20 $\mathrm{mV}$ of the free-corrosion potential and the ensuing current was monitored. The tangent to the $E-i$ plot at the free-corrosion potential is the PR value. The PR value was corrected for ohmic potential drop in the solution between the tip of the Luggin probe and the specimen by means of an $\mathrm{AC}$ measurement technique.

The polarization resistance values were converted to corrosion rates using the Stern-Geary Equation

$$
i_{c o r}=\frac{B_{a} B_{c}}{2.3\left(B_{a}+B_{c}\right)} \cdot \frac{1}{P R}
$$

and Faraday's Law. The constants $B_{a}$ and $B_{c}$ are the anodic and cathodic Tafel slopes, respectively, which are linear portions of the potentiodynamic polarization curve. Since few polarization curves exhibit good Tafel behavior, our standard procedure is to obtain the Tafel constants by drawing tangents to the polarization curve at over-potentials of +75 and $-75 \mathrm{mV}$ from the free-corrosion potential. A typical analysis is shown in Figure 3.2. The polarization curves used were obtained from the Task 2 studies.

Weight losses on the specimens were measured using the interval weight-loss procedure described in ASTM G-1. This technique involves the alternate descaling of the specimen in an inhibited acid and weighing until the visible corrosion products are removed. Weight loss was plotted as a function of descaling time as shown schematically in Figure 3.3. Generally, the specimen weight changes rapidly as the scales are removed but much more gradually when only metal is removed. This behavior is exhibited graphically as a change in slope of the curve. The true weight loss is determined by extrapolating the second slope to the $y$-axis, as shown in Figure 3.3. As a verification of the technique, an unexposed control specimen was included in all descaling measurements. The true weight losses were then converted to corrosion rates, in $\mu \mathrm{m} / \mathrm{yr}$, by dividing the weight loss by the density, the specimen surface area and the test time and converting the units.

The pit depths on the specimens were measured optically, following descaling. A focusing technique was used with a microscope having a calibrated stage. The pits were first located at a low power magnification. At a high power, the microscope was focused on the specimen adjacent to the pit and the stage position recorded. The microscope was then refocused at the pit bottom and the final stage position was recorded; the difference between the two recordings was then calculated. The deepest of up to five pits were reported after each exposure period. 


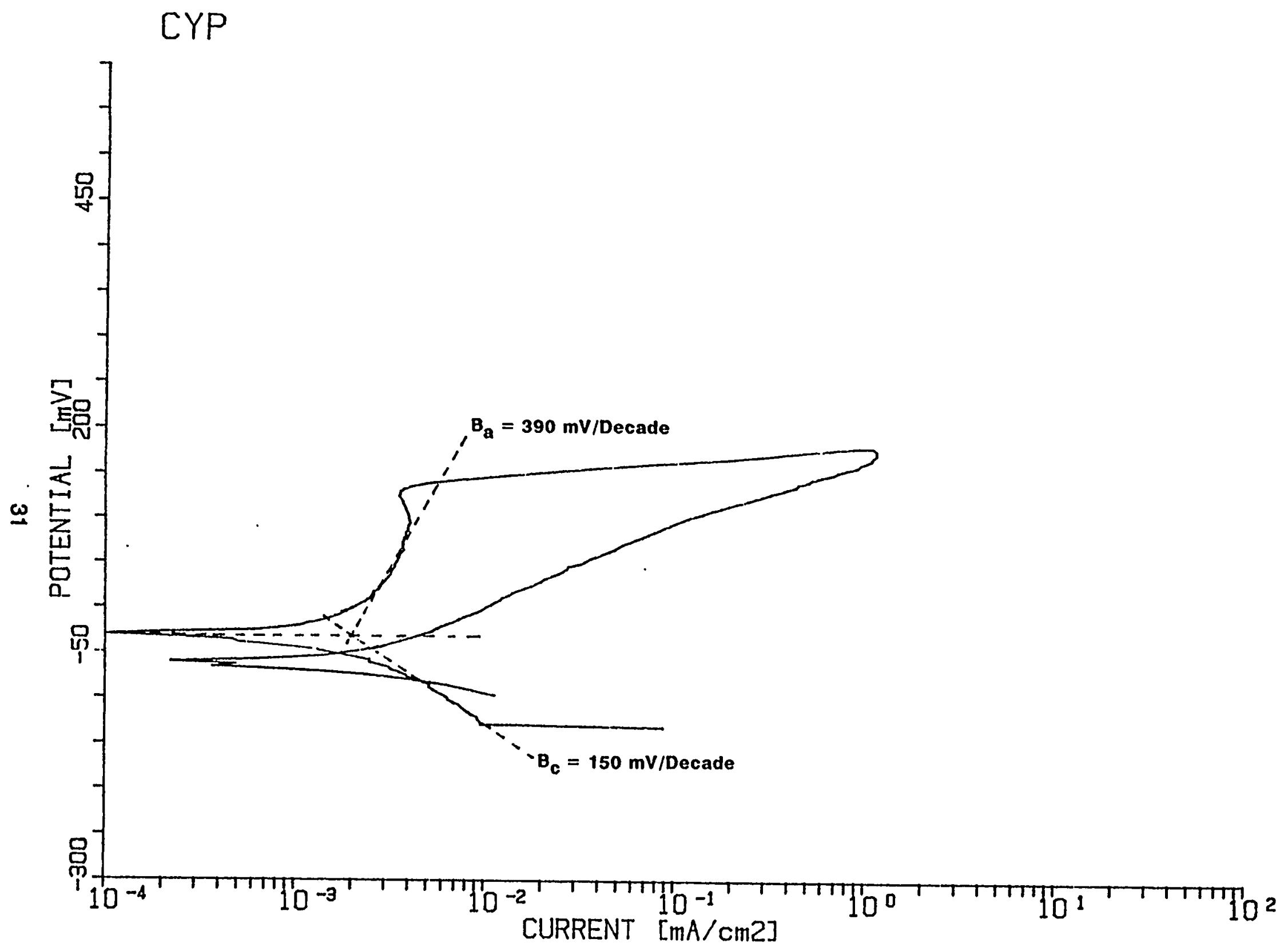

Figure 3.2 CPP Curve For Alloy CDA 102 In Simulated J-13 Well Water Showing The Anodic And Cathodic Tafel Slope Determinations (Beavers-1990). 


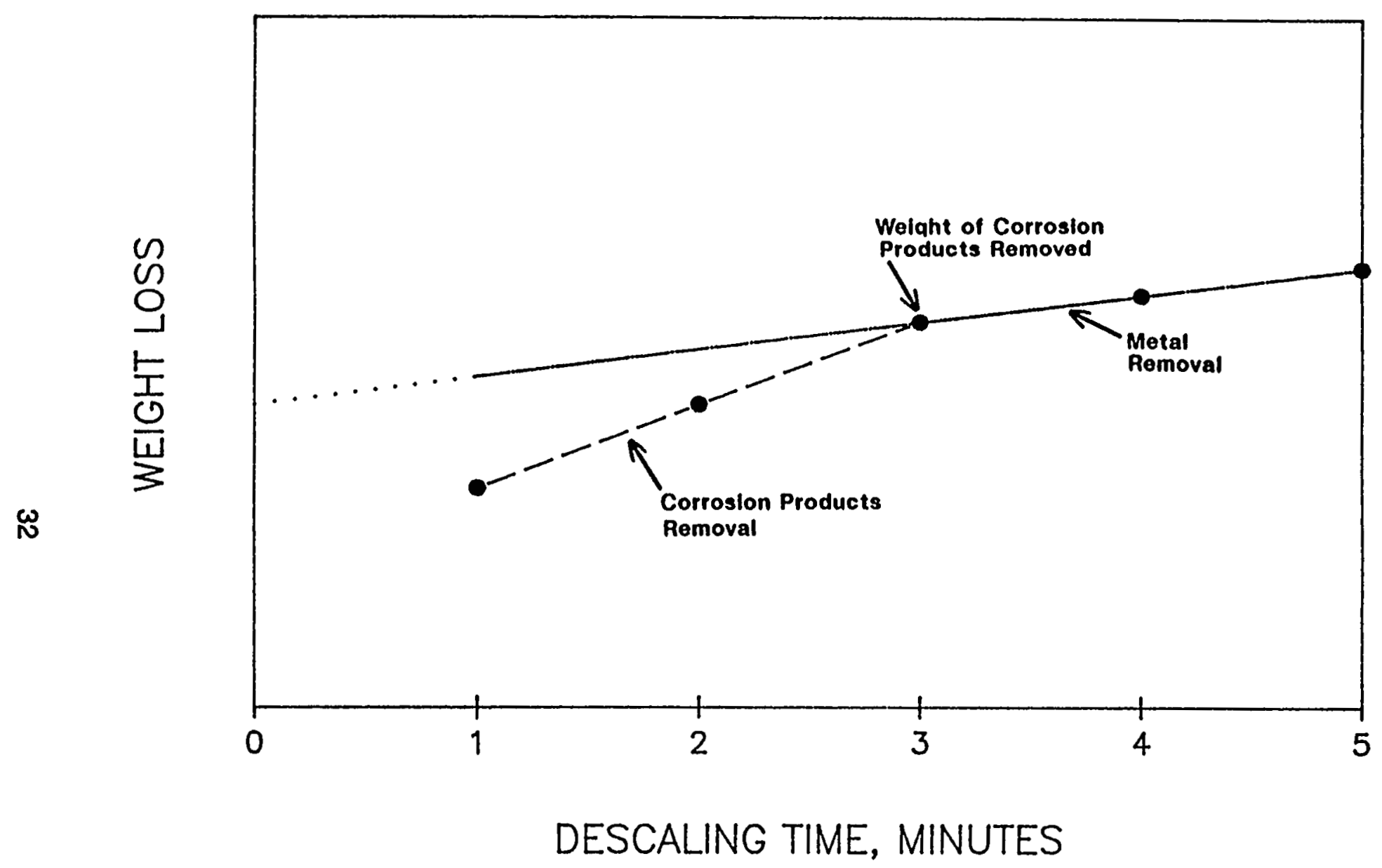

Figure 3.3 Schematic Showing Weight Change As A Function Of Descaling Time For Control (Unexposed) And Test Specimen. 


\section{CORROSION BEHAVIOR IN SIMULATED J-13 WELL WATER}

\section{$4.1 \mathrm{Fe}-\mathrm{Cr}$-Ni Alloys}

\subsubsection{General Corrosion}

Exposure tests of 2039 hours were performed on Alloy $304 \mathrm{~L}$ and Alloy 825 in aerated simulated $\mathrm{J}-13$ well water at $90^{\circ} \mathrm{C}$. A summary of the weight-loss and optical-examination data is given in Table 4.1. These data show that the general corrosion rates, based on weight loss, for both alloys were below the detection limit. Blue interference films were observed on most of the specimens prior to descaling indicating some passive film growth had occurred during the tests. The specimens also generally exhibited light etching beneath deposits and around the crevice washers.

Data from the electrochemical measurements of Alloy $304 \mathrm{~L}$ and Alloy 825 are summarized in Table 4.2 and are exhibited graphically in Figures 4.1 through 4.3. These data also show very low corrosion rates, and in many cases, were below our estimates of the detection limits for the technique. These data also show that the polarization resistance (PR) values for the liquid-phase specimens were higher than for the vapor-phase specimens. Note that PR is inversely proportional to corrosion rate. Nevertheless, the PR measurements indicated very low corrosion rates for both alloys, which is consistent with the weight-loss results. For the vapor-phase specimens, PR values did predict somewhat higher corrosion rates than those measured by means of weight loss; compare Tables 4.1 and 4.2. Comparison of the PR data for the two alloys indicates that the liquid-phase PR values were comparable while the vapor-phase PR values for Alloy 825 were nearly an order of magnitude higher than for Alloy 304L.

Considerable scatter was experienced in the PR measurements and attempts were made to identify the root cause of the scatter. It was concluded that the corrosion rates of the $\mathrm{Fe}-\mathrm{Cr}-\mathrm{Ni}$ alloys were so low, which corresponds to high PR values, that we approached the current limitations of the equipment in the presence of $A C$ noise in the laboratory. In the polarization resistance measurements, we estimated that our accurate detection limit was $10 \mathrm{mV}$ across a 1 megohm resistor which corresponds to a current of $10 \times 10^{-9} \mathrm{amps}$. This corresponds to the upper limit PR values for various specimen surface areas as given in Table 4.3. Note, that for a $5 \mathrm{~cm}^{2}$ specimen surface area (approximate surface area of the liquid-phase specimens), the upper limit PR value, $10000 \mathrm{kohm}-\mathrm{cm}^{2}$ corresponds to $0.05 \mu \mathrm{m} / \mathrm{yr}(0.05 \mathrm{~mm}$ in 1000 years) which is a very acceptable corrosion rate for a waste canister. Even for the vapor-phase electrochemical specimens, which have a much smaller exposed surface area, the upper limit PR value corresponds to $200 \mathrm{kohm}-\mathrm{cm}^{2}$ which is equal to $2.5 \mu \mathrm{m} / \mathrm{yr}$ ( $2.5 \mathrm{~mm}$ in 1000 years). Therefore, the equipment limitations do not impose significant limitations on the PR measurement technique. It also should be pointed out that manual measurements, which have about an order of magnitude better accuracy, were performed in some instances (Table 4.3). 
Table 4.1 Summary of Results Of 510,1011 And 2039 Hour Exposures Of Fe-Cr-Ni Alloys In Aerated Simulated J-13 Well Water At $90^{\circ} \mathrm{C}$.

\begin{tabular}{|c|c|c|c|c|c|c|c|}
\hline Alloy & Phase & $\begin{array}{l}\text { Test } \\
\text { Time } \\
\text { Hours }\end{array}$ & $\begin{array}{l}\text { Specimen } \\
\text { Type }\end{array}$ & $\begin{array}{c}\text { Corrosion } \\
\text { Rate } \\
\mu \mathrm{m} / \mathrm{yr}\end{array}$ & $\begin{array}{l}\text { Maximum } \\
\text { Pit Depth } \\
\mu \mathrm{m}\end{array}$ & Comments & $\begin{array}{c}\text { Specimen } \\
\#\end{array}$ \\
\hline 1825 & Vapor & 510 & Creviced & $<0.2$ & - & Very light, localized etching. & 456 \\
\hline 1825 & Vapor & 1101 & Creviced & $<0.2$ & 24 & Single pit; light etching. & 101112 \\
\hline 1825 & Vapor & 2039 & Creviced & $<0.2$ & - & $\begin{array}{l}\text { Blue interference films; light } \\
\text { elching near crevices and along } \\
\text { scratches. }\end{array}$ & 161718 \\
\hline 1825 & Liquid & 510 & Croviced & $<0.2$ & 11 & $\begin{array}{l}\text { Blue interference films outside } \\
\text { crevices; numerous small pits. }\end{array}$ & 123 \\
\hline 1825 & Liquid & 1011 & Creviced & $<0.2$ & 20 & $\begin{array}{l}\text { Blue interference films and } \\
\text { single pit; etched ring outside } \\
\text { crevices. }\end{array}$ & 789 \\
\hline 1825 & Liquid & 2039 & Creviced & $<0.2$ & 10 & $\begin{array}{l}\text { Blue interference films; light } \\
\text { etching near crevices; several } \\
\text { small pits. }\end{array}$ & 192021 \\
\hline 1825 & $\begin{array}{c}\text { Alt } \\
\text { Immersion }\end{array}$ & 2039 & Croviced & $<0.2$ & - & $\begin{array}{l}\text { Blue interference films; light } \\
\text { etching near crevices. }\end{array}$ & 131415 \\
\hline $304 \mathrm{~L}$ & Vapor & 510 & Creviced & $<0.2$ & - & $\begin{array}{l}\text { Light etching in crevices and } \\
\text { near ID numbers. }\end{array}$ & 101112 \\
\hline 304L & Vapor & 1011 & Creviced & $<0.2$ & - & Light etching near crevices. & 161718 \\
\hline 304L & Vapor & 2039 & Creviced & $<0.2$ & - & $\begin{array}{l}\text { Blue interference films; light } \\
\text { etching near crevices. }\end{array}$ & 456 \\
\hline $304 \mathrm{~L}$ & Liquid & 510 & Creviced & $<0.2$ & - & $\begin{array}{l}\text { Blue interference films; light } \\
\text { elching in crevices. }\end{array}$ & 131415 \\
\hline 304L & Liquid & 1011 & Creviced & $<0.2$ & - & $\begin{array}{l}\text { Moderate efching outside and } \\
\text { under crevices. }\end{array}$ & 192021 \\
\hline $304 \mathrm{~L}$ & Liquid & 2039 & Creviced & $<0.2$ & - & $\begin{array}{l}\text { Blue interference films; light } \\
\text { elching and scaling near crevices }\end{array}$ & 123 \\
\hline $304 \mathrm{~L}$ & $\begin{array}{l}\text { Att } \\
\text { Immersion }\end{array}$ & 2039 & Creviced & $<0.2$ & - & Blue interference films; elching & 789 \\
\hline
\end{tabular}


Table 4.2 Summary Of Results Of Electrochemical Measurements Performed On Fe-Cr-Ni Alloys In Aerated Simulated J-13 Well Water At $90^{\circ} \mathrm{C}$.

\begin{tabular}{|c|c|c|c|c|c|c|c|c|}
\hline \multirow{2}{*}{ Alloy } & \multirow{2}{*}{$\begin{array}{l}\text { Time, } \\
\text { Hours }\end{array}$} & \multicolumn{2}{|c|}{$\begin{array}{l}\text { Polarization } \\
\text { Resistance } \\
\text { kohm }-\mathrm{cm}^{2}\end{array}$} & \multicolumn{2}{|c|}{$\begin{array}{c}\text { Tafel } \\
\text { Slope } \\
\text { mV/decade }\end{array}$} & \multicolumn{2}{|c|}{$\begin{array}{c}\text { Corrosion Rate } \\
\qquad \mu \mathrm{m} / \mathrm{yr}\end{array}$} & \multirow{2}{*}{$\begin{array}{c}\begin{array}{c}E_{c o r} \\
m V\end{array} \\
\text { (SCE) }\end{array}$} \\
\hline & & Vapor & Liquid & $\mathrm{B}_{\mathrm{a}}$ & $B_{c}$ & Vapor & Liquid & \\
\hline 1825 & 173 & 784 & 4390 & 211 & 221 & 0.61 & 0.11 & -85 \\
\hline 1825 & 342 & 1351 & --. & 211 & 221 & 0.35 & -- & -108 \\
\hline 1825 & 509 & 1849 & 52300 & 211 & 221 & 0.26 & 0.01 & -130 \\
\hline 1825 & 1010 & 1603 & 39300 & 211 & 221 & 0.30 & 0.01 & -151 \\
\hline 1825 & 1516 & 2223 & 6407 & 211 & 221 & 0.22 & 0.07 & -168 \\
\hline 1825 & 2022 & 2048 & 6461 & 211 & 221 & 0.23 & 0.07 & -184 \\
\hline 304L & 173 & 182 & 3440 & 493 & 131 & 2.60 & 0.14 & -87 \\
\hline 304L & 342 & 369 & 21100 & 493 & 131 & 1.28 & 0.02 & -95 \\
\hline 304L & 509 & 490 & 25300 & 493 & 131 & 0.96 & 0.02 & -113 \\
\hline 304L & 1010 & 160 & 12700 & 493 & 131 & 2.95 & 0.04 & -97 \\
\hline 304L & 1516 & 226 & 3610 & 493 & 131 & 2.09 & 0.13 & -103 \\
\hline 304L & 2022 & 253 & 7540 & 493 & 131 & 1.87 & 0.06 & -100 \\
\hline
\end{tabular}




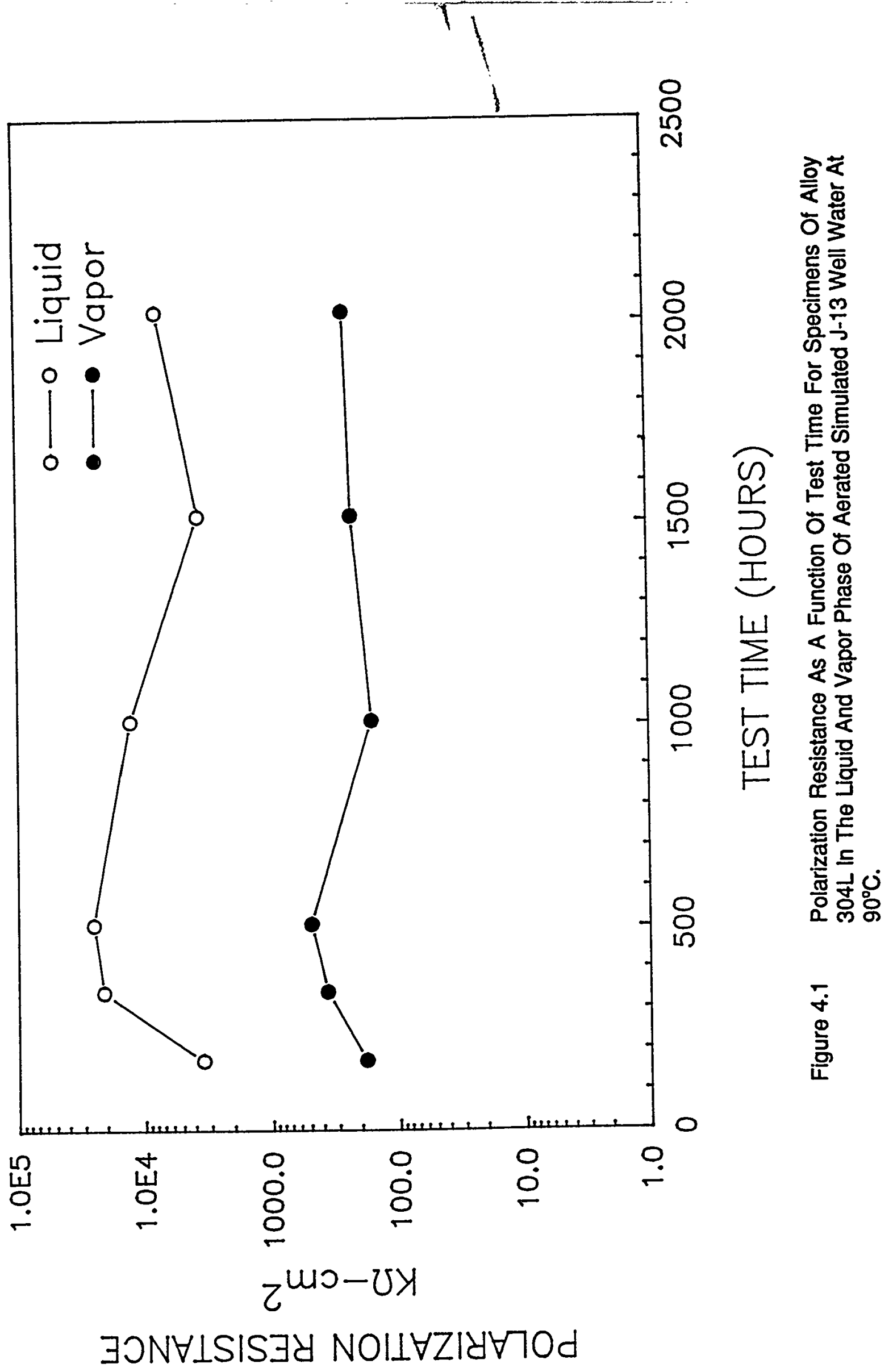




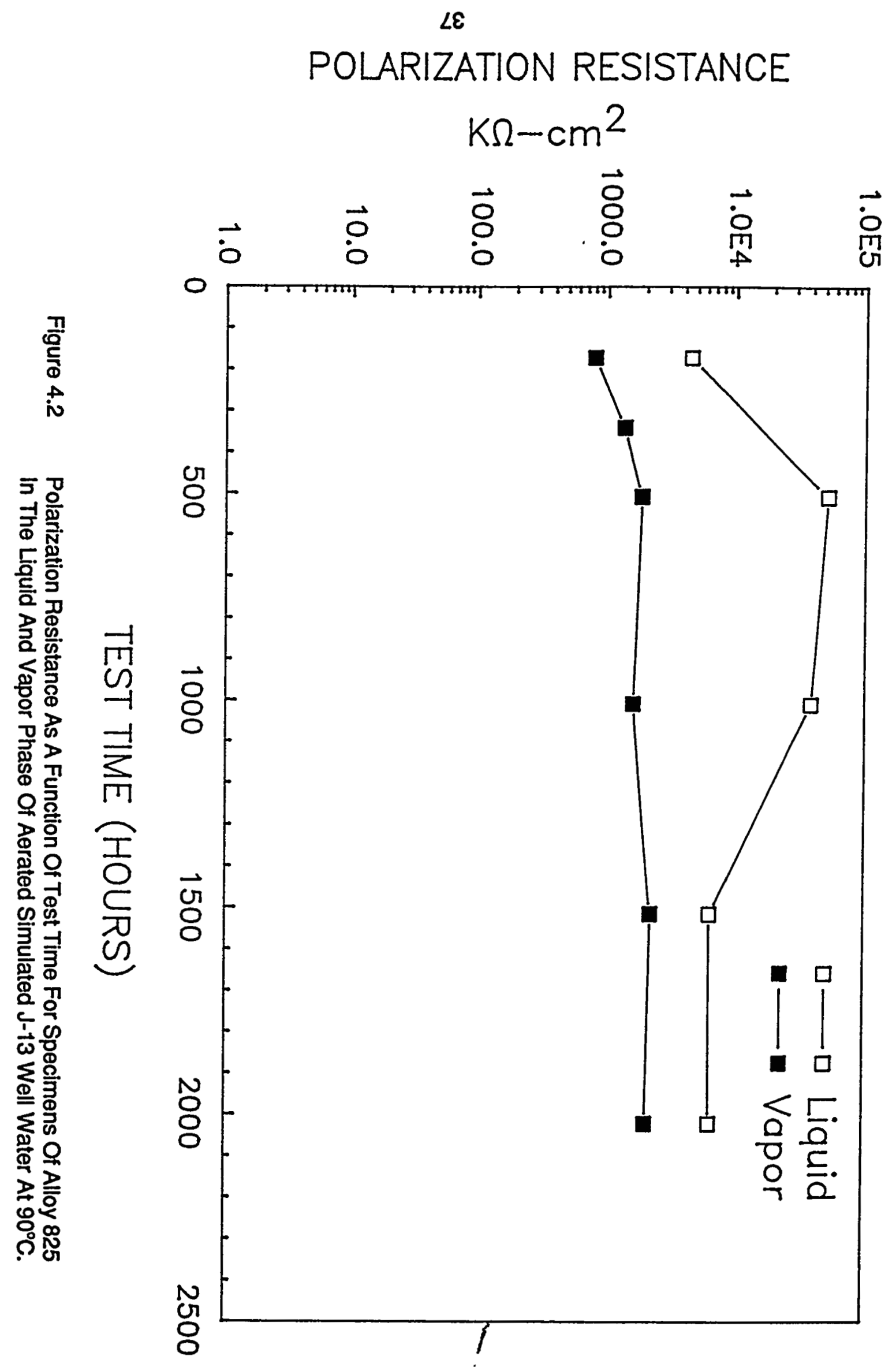




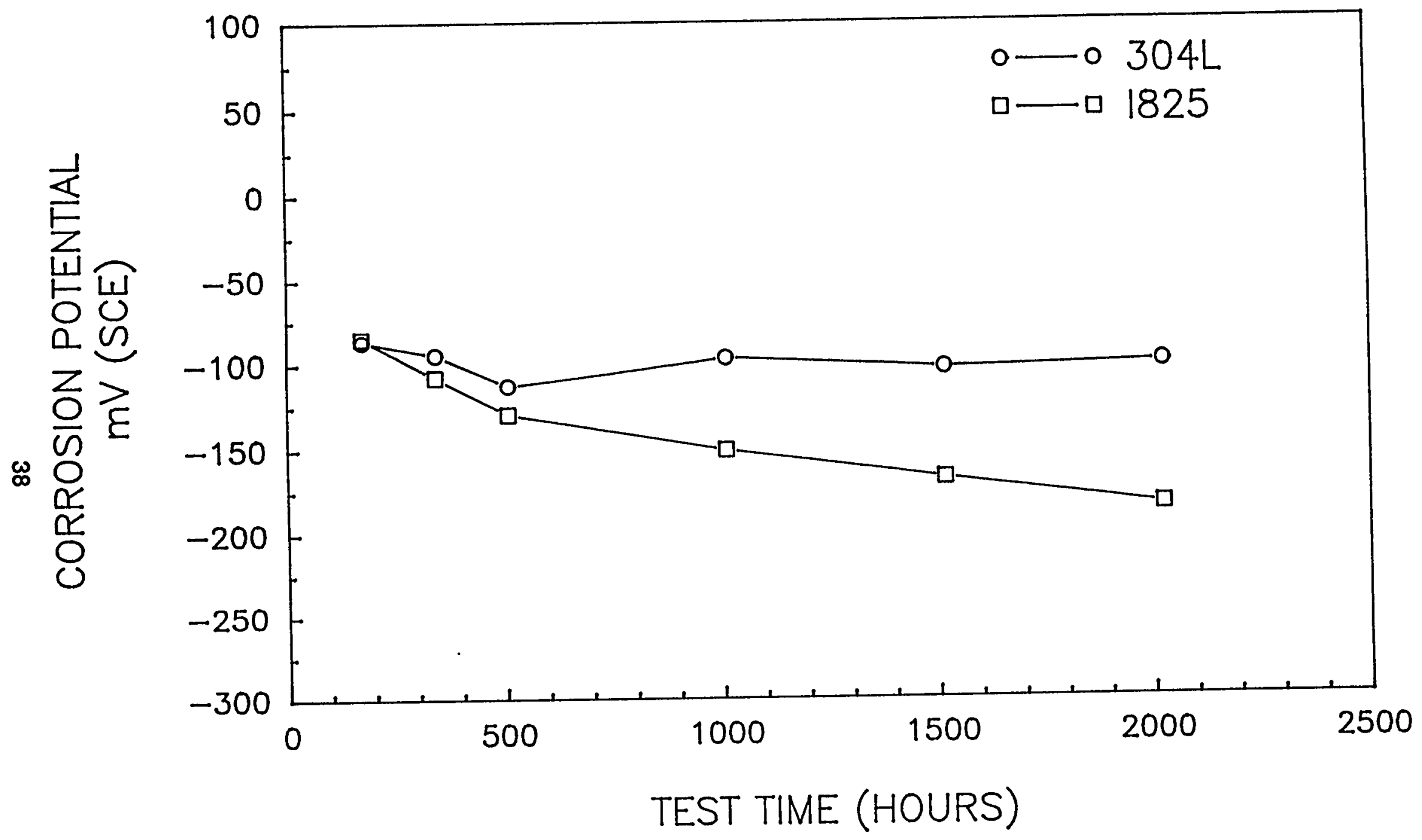

Figure 4.3 Corrosion Potential As A Function Of Test Time For Alloy 304L And Alloy 825 Exposed To The Liquid Phase Of Aerated Simulated J-13 Well Water At $90^{\circ} \mathrm{C}$. 
Table 4.3 Estimated Upper Limit Polarization Resistance Values As A Function Of Specimen Surface Area And Test Procedure.

\begin{tabular}{||c|c|c|}
\hline Test Procedure & $\begin{array}{c}\text { Specimen Surface } \\
\text { Area, } \mathrm{cm}^{2}\end{array}$ & $\begin{array}{c}\text { PR } \\
\text { kohm-cm }\end{array}$ \\
\hline Automated & 0.1 & 200 \\
Automated & 1.0 & 2000 \\
Automated & 5.0 & 10000 \\
Automated & 10.0 & 20000 \\
Manual & 0.1 & 2000 \\
Manual & 1.0 & 20000 \\
Manual & 5.0 & 100000 \\
Manual & 10.0 & 200000 \\
\hline
\end{tabular}




\subsubsection{Localized Corrosion}

In this section, pitting- and crevice-corrosion behavior of the Fe-Cr-Ni Alloys in J-13 well water are discussed. For Alloy 304L, only very slight etching was observed near the crevices in both the liquid and vapor phases. The precision-machined rod showed scaling at the vapor-liquid interface and slight etching only in the vapor phase near the vapor-liquid interface. The localized etching was found to be less than $10 \mu \mathrm{m}$ in depth. The vapor monitor also exhibited similar attack. No pitting was observed for any of the Alloy 304L specimens.

For Alloy 825 , some shallow pitting was observed on several of the liquid-phase specimens. Very light etching was observed near the crevices in both the liquid and vapor phases. Although the precision-machined rod showed no observable attack, the vapor monitor exhibited slight etching near the edges and a few very shallow $(17 \mu \mathrm{m})$ depressions.

The pitting observed on the liquid-phase specimens of Alloy 825 was found to occur on the upper surfaces of the specimens where deposits had accumulated. After 2039 hours, the pits were no deeper than those observed after 1011 or 510 hours exposure, suggesting that the rate of pit propagation greatly decreased with time or that propagation ceased. The pitting was highly unexpected and accordingly, chemical analyses were performed on the test solution and the specimen from the $\mathbf{5 1 0}$ hour exposure. The results of these analyses did not indicate anything unusual about the material. The analysis of the solution indicated somewhat higher chloride levels than expected; the design value was $7 \mathrm{ppm}$ while the measured value was $45 \mathrm{ppm}$.

Alloy 825 would be expected to be resistant to pitting in the $\mathrm{J}-13$ well water environment even with the higher chloride content. Thus, a possible explanation for this behavior is that the specimen surfaces were contaminated during preparation with some species that promoted the pitting. For example, it is well established that iron contamination of stainless steel surfaces can promote pitting in environments where corrosion resistance is marginal.

The elevated chloride content of the simulated J-13 well water probably was a consequence of the $\mathrm{pH}$ adjustment procedure. The quality assurance procedure for preparing the simulated $\mathrm{J}-13$ well water directed that the $\mathrm{pH}$ of the solution be adjusted with hydrochloric acid $(\mathrm{HCl})$. The required amount of $\mathrm{HCl}$ addition was higher than that required in the initial development of the simulated $\mathrm{J}-13$ well water, which was performed at Battelle.

This problem with the simulated $\mathrm{J}-13$ well water preparation is not considered to have a major impact on the results of this task for two reasons. First, comparison of results of cyclic potentiodynamic polarization (CPP) tests for actual and simulated $\mathrm{J}-13$ well water indicated no significant differences for either the two copper-base alloys or for Alloy 304L. Data for Alloy 825 were not available for comparison.

Secondly, the composition of the groundwater that comes in contact with the waste container is expected to be much more concentrated than that of the $\mathrm{J}-13$ well water as a result of thermal concentration. Thus, the composition of the simulated $\mathrm{J}-13$ well water is probably very dilute in comparison to water that will contact the actual container. 


\subsubsection{Stress-Corrosion Cracking}

Constant strain (U-bend) specimens of Alloy 304L and Alloy 825 were included in the sample matrix to evaluate the susceptibility to stress-corrosion cracking (SCC) after selected hours of exposure to simulated $\mathrm{J}-13$ well water at $90^{\circ} \mathrm{C}$. No SCC was observed after 510,1011 , or 2039 hours of exposure.

\subsection{Copper-Base Alloys}

\subsubsection{General Corrosion}

Exposure tests of 2024 hours were performed on Alloy CDA 102 and Alloy CDA 715 in aerated simulated $\mathrm{J}-13$ well water at $90^{\circ} \mathrm{C}$. A summary of the weight-loss data and optical examinations is given in Table 4.4. These data show that the corrosion rates of the Alloy CDA 102 specimens were about an order of magnitude higher than those of the Alloy CDA 715 specimens. Comparison of the 590, 1000, and 2024 hour data for CDA 102 indicates that corrosion rates were reasonably constant for the first 1000 hours of exposure but decreased thereafter. After 2024 hours of exposure, vapor, liquid and alternate-immersion specimens all exhibited comparable corrosion rates. The average corrosion rate for the Alloy CDA 102 specimens after 2000 hours was about $2.5 \mu \mathrm{m} / \mathrm{y}$, which corresponds to a thickness loss of $2.5 \mathrm{~mm}$ ( 0.1 incheș) in a thousand years; this is an acceptable corrosion rate. For Alloy CDA 715, all of the corrosion rates approached the detection limit for the analytical balance. Thus, the trends with respect to time are not considered to be meaningful.

Comparison of the data for the creviced and uncreviced specimens suggests that the presence of the crevices did not measurably affect the weight losses. Optical examination of the specimens did indicate that surface deposits and etching were frequently located near the TFE washers.

Data from the electrochemical measurements of Alloy CDA 102 and Alloy CDA 715 are summarized in Table 4.5 and are exhibited graphically in Figures 4.4 through 4.6. As with the $\mathrm{Fe}-\mathrm{Cr}-\mathrm{Ni}$ alloys, the polarization resistance values are higher in the liquid than in the vapor which indicate higher corrosion rates in the vapor phase. These data are not consistent with the weightloss analyses where similar corrosion rates were observed for specimens in the two phases. The discrepancy may be a consequence, in part, of the two different electrochemical techniques used for the vapor and liquid-phase PR measurements or spurious electrochemical reactions which contribute a current in the measurement but are not associated with metal loss. A significant observation is the fact that PR values for Alloy CDA 102 tended to increase with time whereas no trend was evident in the PR data for Alloy CDA 715. The increase in PR with time for Alloy CDA 102 appears to correlate with an increase in the free-corrosion potential, suggesting that a slow passivation phenomenon occurred with the CDA 102 specimens. This trend was verified by the weight-loss data.

Comparison of Figure 4.4 with Figure 4.5 indicates that the polarization resistance values for both the liquid and vapor phases were higher for Alloy CDA 715 than for Alloy CDA 102 which indicates a higher rate of corrosion for Alloy CDA 102. These trends were consistent with the 
Table 4.4 Summary Of Results Of 2024 Hour Exposure Of Copper-Base Alloys In Aerated Simulated $\mathrm{J}-13$ Well Water At $90^{\circ} \mathrm{C}$.

\begin{tabular}{|c|c|c|c|c|c|c|c|}
\hline Alloy & Phase & $\begin{array}{l}\text { Test } \\
\text { Time } \\
\text { Hours }\end{array}$ & $\begin{array}{l}\text { Specimen } \\
\text { Type }\end{array}$ & $\begin{array}{c}\text { Comosion } \\
\text { Rale } \\
\mu \mathrm{m} / \mathrm{yr}\end{array}$ & $\begin{array}{c}\text { Maximum } \\
\text { Pit Depth } \\
\mu \mathrm{m}\end{array}$ & Comments & $\begin{array}{c}\text { Specimen } \\
\#\end{array}$ \\
\hline 102 & Vapor & 590 & Uncreviced & 3.17 & $<10$ & $\begin{array}{l}\text { Spotty light etching beneath } \\
\text { deposits }\end{array}$ & 616568 \\
\hline 102 & Vapor & 590 & Crevicod & 3.07 & $<10$ & Light etching around crevices & 636467 \\
\hline 102 & Vapor & 1000 & Uncreviced & 4.15 & 32 & Pits near scratches & 515253 \\
\hline 102 & Vapor & 1000 & Creviced & 12.7 & 34 & Pits near scratches & 495455 \\
\hline 102 & Vapor & 2024 & Uncreviced & 2.23 & 18 & $\begin{array}{l}\text { Light etching; a fow moderale } \\
\text { pits }\end{array}$ & 798184 \\
\hline 102 & Vapor & 2024 & Creviced & 1.67 & 10 & $\begin{array}{l}\text { Light etching; a few shallow } \\
\text { pits }\end{array}$ & 737583 \\
\hline 102 & Liquid & 590 & Uncreviced & 8.16 & 10 & $\begin{array}{l}\text { Moderate etching beneath } \\
\text { deposits }\end{array}$ & 707172 \\
\hline 102 & Liquid & 590 & Creviced & 5.35 & $<10$ & Light etching around crevices & 626669 \\
\hline 102 & Liquid & 1000 & Uncreviced & 4.76 & 16 & Etching under deposits & 575859 \\
\hline 102 & Liquid & 1000 & Creviced & 4.25 & 15 & $\begin{array}{l}\text { Light etching; pits in etched } \\
\text { areas }\end{array}$ & 505660 \\
\hline 102 & Liquid & 2024 & Uncreviced & 3.44 & $<10$ & Light elching; no pits & 778082 \\
\hline 102 & Liquid & 2024 & Creviced & 2.48 & 12 & $\begin{array}{l}\text { Light etching; a fow shallow } \\
\text { pits }\end{array}$ & 747678 \\
\hline 102 & $\begin{array}{l}\text { Att } \\
\text { Immersion }\end{array}$ & 2024 & Uncreviced & 2.52 & $<10$ & Light etching; no pits & 858687 \\
\hline 102 & $\begin{array}{l}\text { Alt } \\
\text { Immersion }\end{array}$ & 2024 & Creviced & 2.87 & $<10$ & Light etching; no pits & 888990 \\
\hline
\end{tabular}




\begin{tabular}{|c|c|c|c|c|c|c|c|}
\hline Alloy & Phase & $\begin{array}{l}\text { Test } \\
\text { Time } \\
\text { Hours }\end{array}$ & $\begin{array}{l}\text { Specimen } \\
\text { Type }\end{array}$ & $\begin{array}{c}\text { Corrosion } \\
\text { Rate } \\
\mu \mathrm{m} / y r\end{array}$ & $\begin{array}{c}\text { Maximum } \\
\text { Pit Depth } \\
\mu \mathrm{m}\end{array}$ & Comments & $\begin{array}{c}\text { Specimen } \\
\$\end{array}$ \\
\hline 715 & Vapor & 590 & Uncreviced & 0.83 & $<10$ & Small lightly etched spots & 343536 \\
\hline 715 & Vapor & 590 & Creviced & 0.83 & $<10$ & Small lightly etched spots & 313233 \\
\hline 715 & Vapor & 1000 & Uncreviced & 0.18 & $<10$ & $\begin{array}{l}\text { Small lighlly etched spots; } \\
\text { a lew pits }\end{array}$ & 456 \\
\hline 715 & Vapor & 1000 & Creviced & 0.31 & 10 & $\begin{array}{l}\text { Small lightly etched spots; } \\
\text { a few pits }\end{array}$ & 123 \\
\hline 715 & Vapor & 2024 & - Uncreviced & 0.28 & 46 & $\begin{array}{l}\text { Small lightly etched spots; } \\
\text { a few deep pits }\end{array}$ & 222324 \\
\hline 715 & Vapor & 2024 & Crevicod & 0.37 & 53 & $\begin{array}{l}\text { Numerous pits; some deop crevice } \\
\text { attack beneath washers }\end{array}$ & 192021 \\
\hline 715 & Liquid & 590 & Uncreviced & 0.31 & $<10$ & Light etching & 252627 \\
\hline 715 & Liquid & 590 & Creviced & $<0.1$ & $<10$ & Light etching & 282930 \\
\hline 715 & Liquid & 1000 & Uncreviced & 0.25 & $<10$ & Light elching & 101112 \\
\hline 715 & Liquid & 1000 & Creviced & 0.25 & $10-12$ & Etched areas outside crevices & 789 \\
\hline 715 & Liquid & 2024 & Uncreviced & 0.24 & 21 & $\begin{array}{l}\text { Light etching; a few small pits } \\
\text { near scralches }\end{array}$ & 131415 \\
\hline 715 & Liquid & 2024 & Creviced & 0.17 & 10 & $\begin{array}{l}\text { Considerable elching; marbled } \\
\text { appearance }\end{array}$ & 161718 \\
\hline 715 & $\begin{array}{l}\text { Att } \\
\text { Immersion }\end{array}$ & 2024 & Uncreviced & 0.27 & 32 & Etching; considerable pitting & 373839 \\
\hline 715 & $\begin{array}{l}\text { Att } \\
\text { Immersion }\end{array}$ & 2024 & Creviced & 0.27 & 22 & Etching; moderale & 404142 \\
\hline
\end{tabular}


Table 4.5 Summary Of Results Of Electrochemical Measurements Performed On CopperBase Alloys In Aerated Simulated J-13 Well Water At $90^{\circ} \mathrm{C}$.

\begin{tabular}{|c|c|c|c|c|c|c|c|c|}
\hline \multirow[b]{2}{*}{ Alloy } & \multirow{2}{*}{$\begin{array}{l}\text { Time, } \\
\text { Hours }\end{array}$} & \multicolumn{2}{|c|}{$\begin{array}{l}\text { Polarization } \\
\text { Resistance } \\
\text { kohm - } \mathrm{cm}^{2}\end{array}$} & \multicolumn{2}{|c|}{$\begin{array}{c}\text { Tafel } \\
\text { Slope } \\
\text { mV/decade }\end{array}$} & \multicolumn{2}{|c|}{$\begin{array}{c}\text { Corrosion Rate } \\
\qquad \mu \mathrm{m} / \mathrm{yr}\end{array}$} & \multirow{2}{*}{$\frac{\begin{array}{c}E_{\text {cor }} \\
m V(S C E)\end{array}}{\text { Liquid }}$} \\
\hline & & Vapor & Liquid & $\mathrm{B}_{\mathrm{a}}$ & $B_{c}$ & Vapor & Liquid & \\
\hline 102 & 361.5 & 2.05 & 42.5 & 390 & 150 & 534 & 25.8 & -58 \\
\hline 102 & 600 & 2.34 & 89.1 & 390 & 150 & 468 & 12.3 & -54 \\
\hline 102 & 765 & 1.75 & 52.4 & 390 & 150 & 626 & 20.9 & -49 \\
\hline 102 & 933 & 1.94 & 72.9 & 390 & 150 & 566 & 15.1 & -44 \\
\hline 102 & 1101 & 1.07 & 50.0 & 390 & 150 & 1025 & 21.9 & -78 \\
\hline 102 & 1341 & 1.74 & 145 & 390 & 150 & 631 & 7.57 & -51 \\
\hline 102 & 1700 & 4.47 & 233 & 390 & 150 & 246 & 4.72 & -13 \\
\hline 715 & 361.5 & 28.1 & 192 & 203 & 123 & 26.6 & 3.90 & -47 \\
\hline 715 & 600 & 18.8 & 163 & 203 & 123 & 39.8 & 4.59 & -73 \\
\hline 715 & 765 & 18.6 & 7.59 & 203 & 123 & 40.2 & 98.7 & -266 \\
\hline 715 & 933 & 27.4 & 228 & 203 & 123 & 27.4 & 3.29 & -11 \\
\hline 715 & 1101 & 14.8 & 297 & 203 & 123 & 50.6 & 2.53 & -57 \\
\hline 715 & 1341 & 16.3 & 187 & 203 & 123 & 46.1 & 4.01 & -55 \\
\hline 715 & 1700 & 16.9 & 218 & 203 & 123 & 44.4 & 3.43 & -27 \\
\hline
\end{tabular}




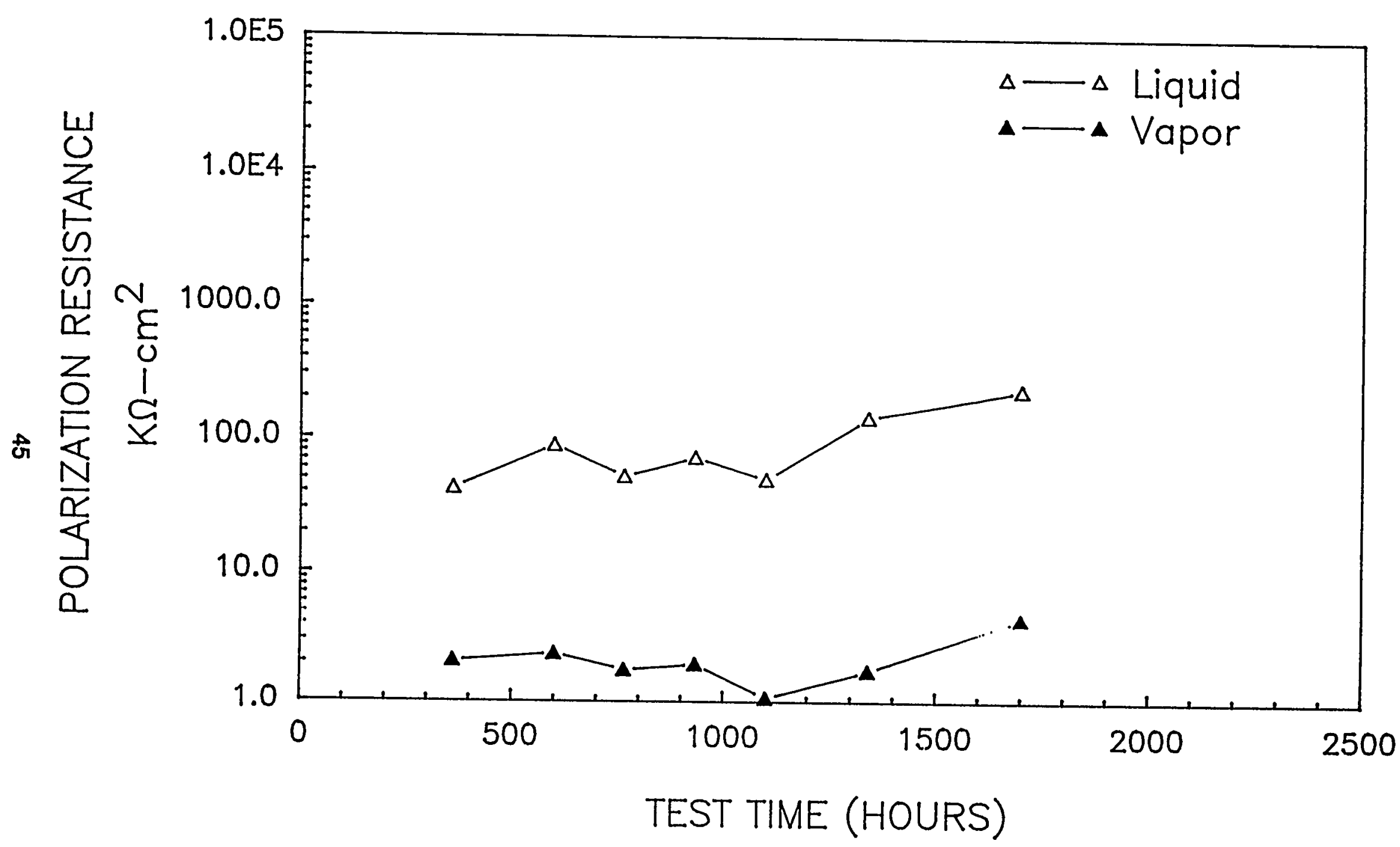

Figure 4.4 Polarization Resistance As A Function Of Test Time For Specimens Of Alloy CDA 102 In The Liquid And Vapor Phase Of Aerated Simulated J-13 Well Water
At $90^{\circ}$. 


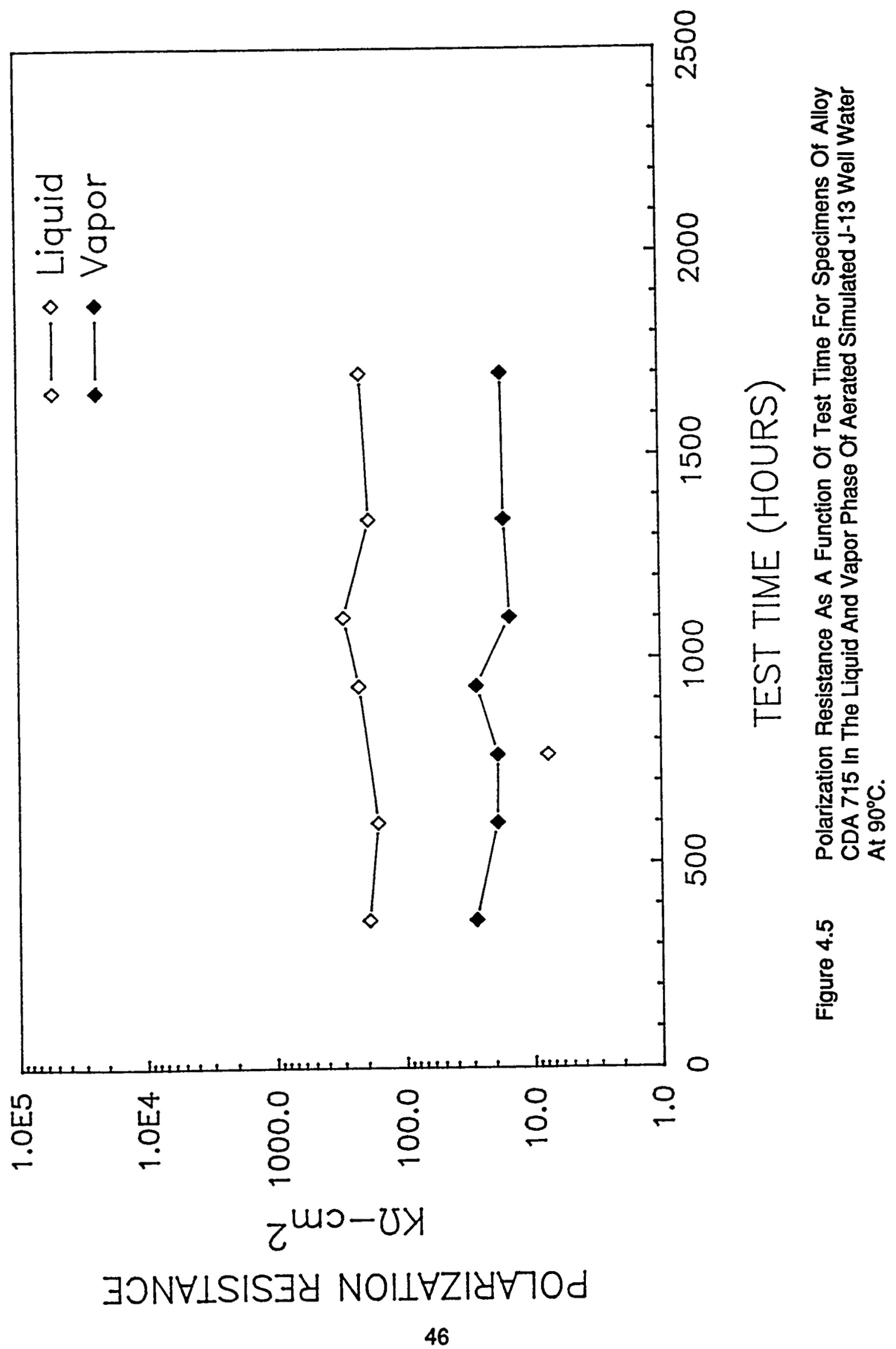




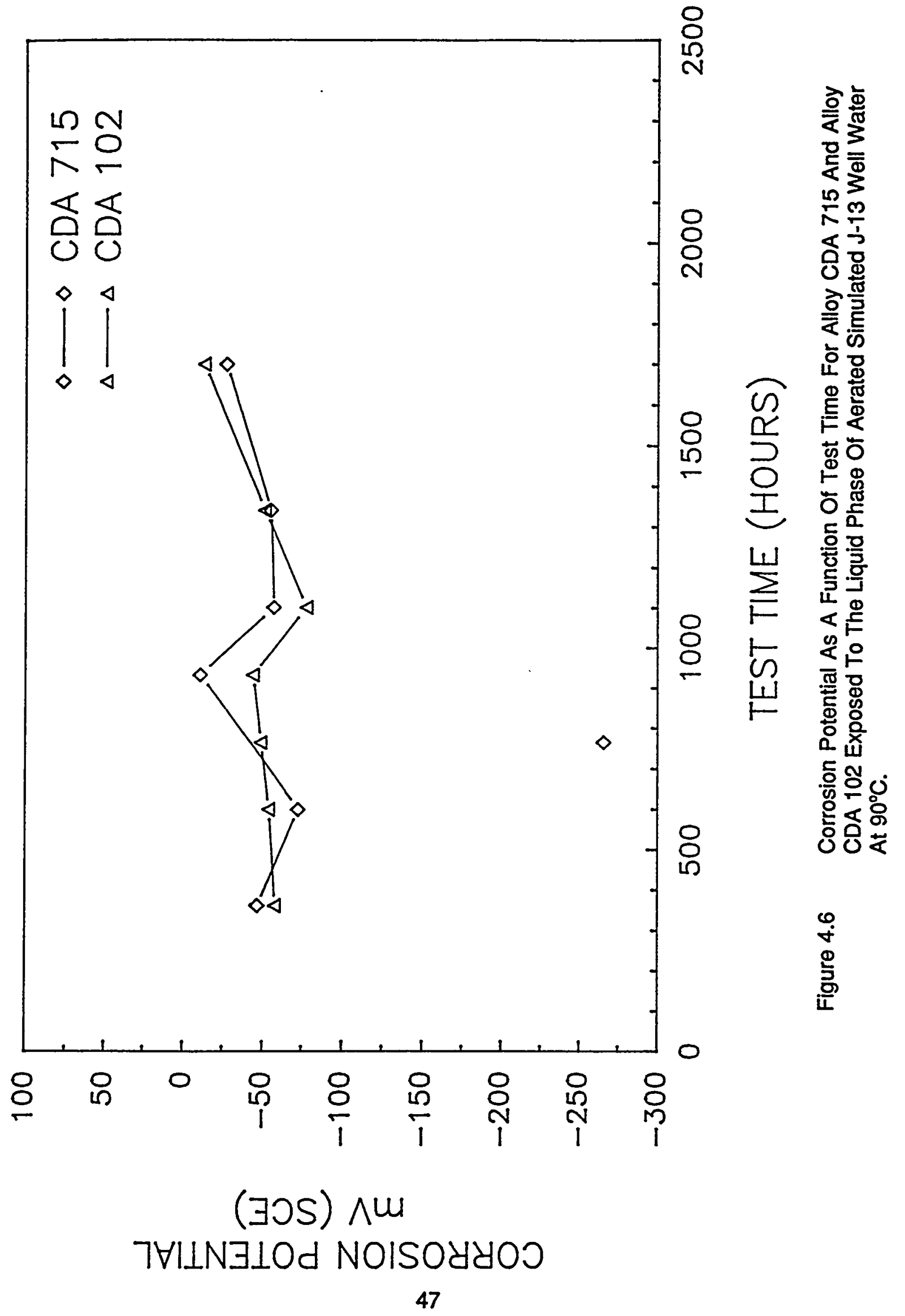


weight-loss data (Table 4.4) which show that Alloy CDA 102 consistently exhibited higher rates of general corrosion than Alloy CDA 715.

The corrosion rates calculated using the Stern-Geary equation and given in Table 4.5 are considerably higher than those obtained from weight loss in this study. It is probable that the discrepancy is the result of spurious electrochemical reactions. Electrochemical techniques occasionally indicate higher rates of corrosion than weight loss where spurious electrochemical reactions are occurring.

\subsubsection{Localized Corrosion}

The pitting data in Table 4.4 for Alloy CDA 715 are of considerable interest. After 1000 hours of exposure, only a few incipient pits were observed and these were generally below the detection limit of the measurement technique, which is 5-10 $\mu \mathrm{m}$. On the other hand, numerous and deep pits were found on the vapor-phase specimens of Alloy CDA 715 after 2024 hours exposure to aerated simulated $\mathrm{J}-13$ well water at $90^{\circ} \mathrm{C}$ (Figure 4.7). Pitting was most severe on specimens near the vapor-liquid interface where deposits had formed on the specimens as a result of alternate wetting and drying from slight changes in the liquid level in the vessel. The machined-rod specimen of Alloy CDA 715 also experienced pitting and deposit formations at the vapor-liquid interface but the curvature of the specimen surface precluded accurate measurements of the depth of those pits. The maximum depth of pitting observed in Alloy CDA $715,53 \mu \mathrm{m}$ in 2024 hours, corresponds to a pit depth of 0.23 meters in 1000 years assuming linear growth kinetics. Of course, it is probably unreasonable to assume that linear growth will occur. Nevertheless, these results point to the need to perform long-term exposure tests to better characterize the long-term performance of the copper-base alloys.

The pitting behavior of Alloy CDA 102 was somewhat different from that of Alloy CDA 715. Only incipient pits were found on the Alloy CDA 102 specimens after 590 hours of exposure, but measurable pits were found after 1000 hours. The pits were deepest in the vapor-phase specimens and approached $35 \mu \mathrm{m}$. However, significant pit propagation did not occur after that time. In fact, measured pit depths were greater after 1000 hours than after 2024 hours, suggesting that the rate of pit propagation in this system falls off rapidly with time.

Results of research performed at Cortest Columbus Technologies (Beavers - 1988) indicate that great care should be taken in interpreting the results of electrochemical studies performed on the copper-base alloys in Tuff environments. On Alloy CDA 102, two distinct types of corrosion processes have been associated with essentially identical polarization curves. In several simulated groundwaters, potentiodynamic polarization curves containing hysteresis have been obtained. In one environment, the hysteresis on the reverse scan was correlated with classical pitting. However, in several other environments, the hysteresis was associated with regions of passive film color change on the specimen, without apparent increases in rates of attack. This color change may be associated with a change in oxidation state of the film (e.g. from $\mathrm{Cu}^{+}$to $\mathrm{Cu}^{2+}$ ) and/or may represent the early stages of film breakdown. Further research is needed to investigate this phenomenon. 


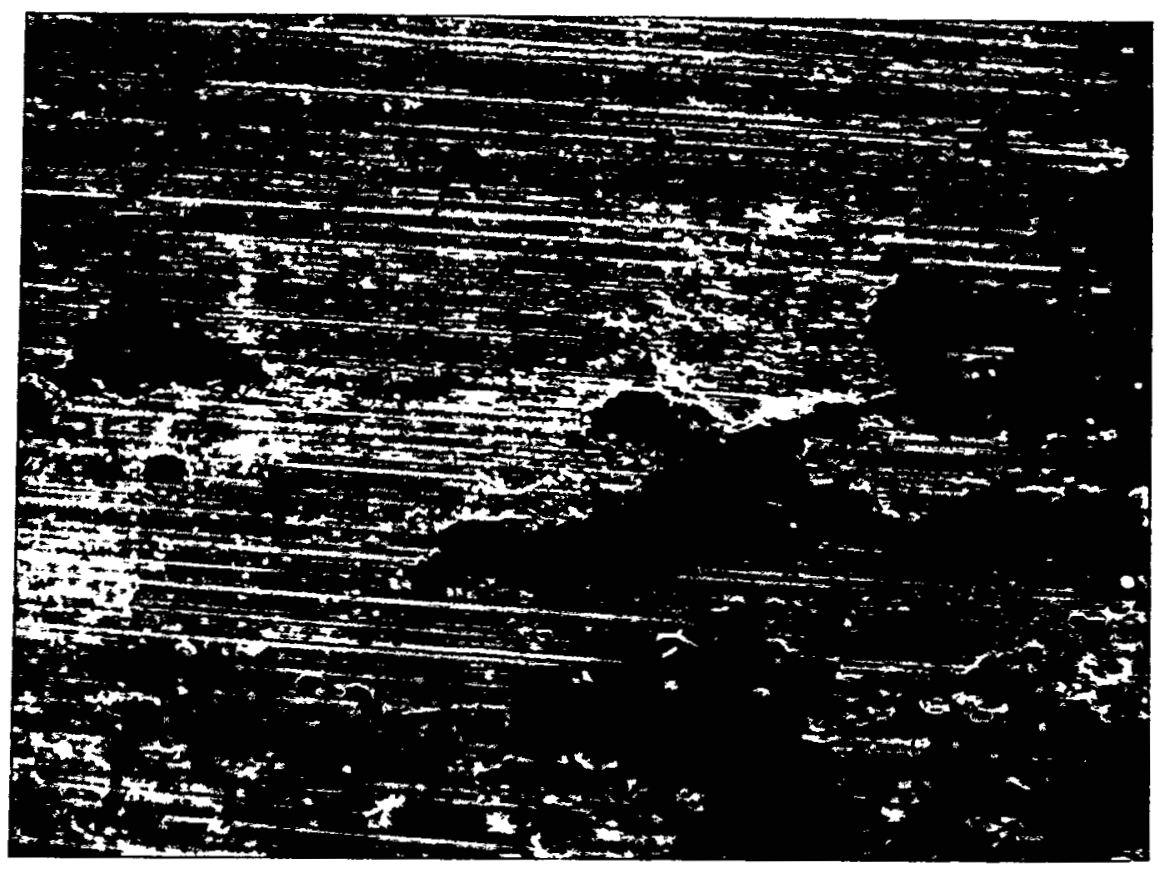

(a)

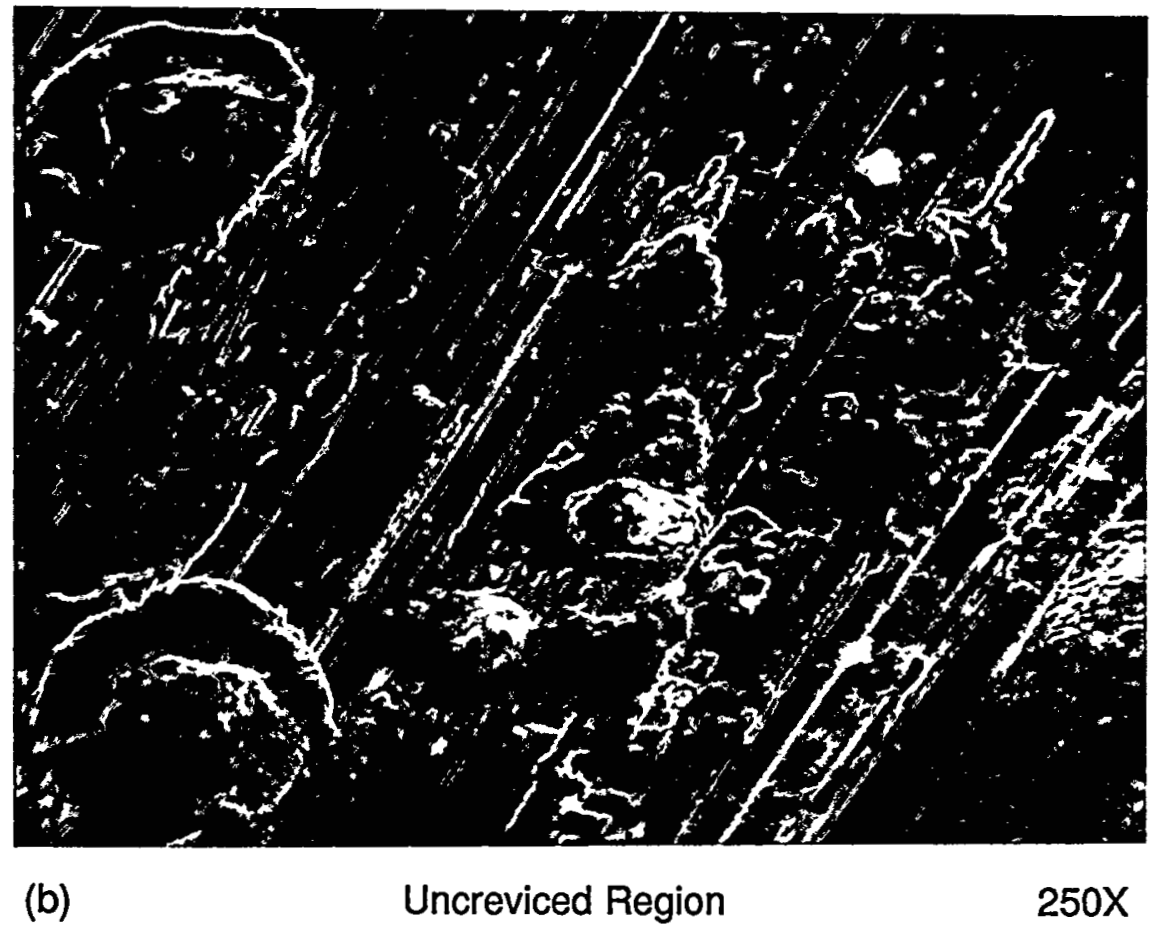

Figure 4.7 Scanning Electron Microscope (SEM) Photographs Of Creviced CDA 715 Specimen Exposed In The Vapor Phase Above Aerated Simulated J-13 Well Water For 2024 Hours. 


\subsubsection{Stress-Corrosion Cracking}

Constant-strain (U-bend) specimens were also included in the sample matrix to evaluate the susceptibility to SCC after selected hours of exposure to simulated $\mathrm{J}-13$ well water at $90^{\circ} \mathrm{C}$. No SCC was observed after 590,1000, or 2024 hours of exposure although etching and pitting were observed on both Alloy CDA 102 and Alloy CDA 715 specimens in both the vapor and liquid phases.

In spite of the apparent good SCC performance in the above tests, cracking remains a potentially serious problem for the copper-base alloys. As shown in Table 4.6, historically, SCC of copperbase alloys has been observed in numerous environments including sulfates, nitrates, nitrites, ammonia, humid air and steam. While $\mathrm{Cu}-\mathrm{Zn}$ alloys predominate in the table, this may reflect, in part, the fact that the brasses are used extensively and more stress-corrosion research has been performed on these alloys than on other alloys. It is generally established that pure copper and copper-nickel alloys are more resistant to SCC than are most other copper-base alloys. However, as shown in Table 4.6, these alloys are susceptible to SCC in several of the reported cracking environments. Further research is needed to investigate some of these environmental species that may be formed as a result of radiolysis of the $\mathrm{J}-13$ well water. 
Table 4.6 Summary Of Environments Known To Promote Stress-Corrosion Cracking Of Copper-Base Alloys.

\begin{tabular}{||l|l|l||}
\hline \multicolumn{1}{|c|}{ Environment } & \multicolumn{1}{|c|}{ Alloy } & \multicolumn{1}{c|}{ Reference } \\
\hline Ammonia & Pure Copper, Cu-Ni & Thompson-1944 \\
Nitrites & Pure Copper & Benjamin-1983 \\
Steam & Al Bronze & Klement-1959 \\
Steam & Cu-Ni & Sato-1974a \\
Ammonia & Al Brass & Sato-1974a \\
Room Temperature Humid & Cu-Zn Alloys & Sato-1974b \\
Air & Cu-Zn Alloys & Kawashima-1979 \\
$\mathrm{SO}_{4}{ }^{2-}$ & Cu-Zn & Graf-1969 \\
$\mathrm{Nitrates}^{2}$ & Cu-Zn & Kawashima-1977 \\
$\mathrm{ClO}_{3}^{-}$ & \\
\hline
\end{tabular}




\section{CORROSION BEHAVIOR IN AN ACTIVE PITTING ENVIRONMENT}

\section{$\underline{5.1 \text { Fe-Cr-Ni Alloys }}$}

\subsubsection{General Corrosion}

Exposure tests of 2783 hours were performed on Alloy 304L and Alloy 825 in aerated Solution No. 20 at $90^{\circ} \mathrm{C}$. Solution No. 20 was selected from the experimental test matrix (Table 2.5) because it was found to be an active pitting environment for the Fe-Cr-Ni alloys based on potentiodynamic polarization tests. The composition of Solution No. 20 is given in Table 5.1 where it can be seen that the solution is high in the aggressive species chloride, fluoride and nitrite. Table 5.1 also shows that Solution No. 20 does not contain hydrogen peroxide $\left(\mathrm{H}_{2} \mathrm{O}_{2}\right)$. In these tests, the solution was hydrogen peroxide free during the first 2200 hours of exposure. For the remainder of the tests, hydrogen peroxide was added periodically to evaluate its effects on pitting of the alloys. Further details are given in section 5.1.2.

A summary of the weight-loss data is given in Tables 5.2 and 5.3. These data indicate that general corrosion rates, based on weight loss, were very low both prior to and after peroxide additions. The corrosion rates of the Alloy 304L specimens, based on weight loss, increased slightly for the last exposure period. This probably was due to the initiation of pitting on the specimens as a result of addition of hydrogen peroxide to the test solutions.

Data from the electrochemical measurements of Alloy 304L and Alloy 825 are summarized in Table 5.4 and exhibited graphically in Figures 5.1 through 5.3. These data also indicate very low corrosion rates prior 2200 hours of exposure, which was when the hydrogen peroxide additions were started; the low corrosion rates correspond to the high polarization resistance (PR) values. These PR values approached or were above our estimates for the detection limits for the measurement technique.

The very low corrosion rates can be explained by comparison of the corrosion potential ( $\left.E_{\text {cor }}\right)$ values shown in Figure 5.3 with the potentiodynamic polarization curves for these alloys in Figures 5.4 and 5.5. The values measured for the corrosion potentials fall within the passive potential range for both alloys in Solution No. 20.

\subsubsection{Localized Corrosion}

A summary of the results of optical examinations of the specimens is given in Tables 5.2 and 5.3. These data show that very slight scaling was observed at the crevices in both the liquid and vapor phases for both alloys after 1029 hours of exposure. Mechanical removal of this scale on the liquid-phase specimens of both alloys revealed very slight etching underneath the scale. However, the quantity of scale was insufficient to require chemical descaling. No pitting attack was observed on either Alloy 304L or Alloy 825 specimens after 1029 hours (prior to $\mathrm{H}_{2} \mathrm{O}_{2}$ 
Table 5.1 Chemical Composition Of J-13 Well Water And Solution No. 20 From The Experimental Test Matrix.

\begin{tabular}{|c|c|c|c|}
\hline $\begin{array}{l}\text { Environmental } \\
\text { Species }\end{array}$ & $\begin{array}{c}\mathrm{J}-13 \text { Well Water } \\
\mathrm{mg} /\end{array}$ & $\begin{array}{c}\text { Simulated } \\
\mathrm{J}-13 \text { Well Water } \\
\mathrm{mg} / 1\end{array}$ & $\begin{array}{c}\text { Solution No. } 20 \\
\mathrm{mg} / \mathrm{l}\end{array}$ \\
\hline $\mathrm{pH}$ & 7.6 & $7.0 \pm 0.2$ & 10.0 \\
\hline $\mathrm{SiO}_{2}$ & 58 & 64.2 & 2.2 \\
\hline $\mathrm{HCO}_{3}^{-}$ & 125 & 121 & 0.4 \\
\hline$F^{-}$ & 2.2 & 1.7 & 200 \\
\hline $\mathrm{Cl}^{-}$ & 6.9 & 6.4 & 1000 \\
\hline $\mathrm{NO}_{3}^{-}$ & 9.6 & 12.4 & 0.2 \\
\hline $\mathrm{SO}_{4}{ }^{2-}$ & 18.7 & 19.2 & • \\
\hline $\mathrm{NO}_{2}^{-}$ & - & - & 200 \\
\hline $\mathrm{H}_{2} \mathrm{O}_{2}$ & - & - & 0.0 \\
\hline $\mathrm{Al}^{3+}$ & 0.012 & - & 0.8 \\
\hline $\mathrm{Fe}^{2+}$ & 0.006 & - & 0.0 \\
\hline $\mathrm{Ca}^{2+}$ & 12.5 & 12.0 & 0.8 \\
\hline $\mathrm{Mg}^{2+}$ & 1.9 & 1.7 & 0.8 \\
\hline $\mathrm{K}^{+}$ & 5.1 & 5.5 & 408 \\
\hline $\mathrm{Na}^{+}$ & 44 & 46 & * \\
\hline $\mathrm{PO}_{4}{ }^{3-}$ & 0.12 & - & 2.0 \\
\hline Oxalic Acid & - & - & 0.0 \\
\hline
\end{tabular}

${ }^{*} \mathrm{Na}^{+}$and $\mathrm{SO}_{4}{ }^{2-}$ were used to balance the composition. 
Table 5.2 Summary Of Results Of Exposure Of Creviced Specimens Of Alloy $304 \mathrm{~L}$ In Aerated Solution No. 20 At $90^{\circ} \mathrm{C}$.

\begin{tabular}{|c|c|c|c|c|c|c|c|}
\hline Alloy & Phase & $\begin{array}{l}\text { Test } \\
\text { Time } \\
\text { Hours }\end{array}$ & $\begin{array}{l}\text { Specimen } \\
\text { Type }\end{array}$ & $\begin{array}{c}\text { Corrosion } \\
\text { Rate } \\
\mu \mathrm{m} / \mathrm{yr}\end{array}$ & $\begin{array}{c}\text { Maximum } \\
\text { Pit Depth } \\
\mu \mathrm{m}\end{array}$ & Comments & Specimen \# \\
\hline $304 \mathrm{~L}$ & Vapor & 508 & Creviced & $<0.14$ & -. & No attack, slight scaling. & L24,L23,L22 \\
\hline $304 L$ & Liquid & 508 & Creviced & $<0.14$ & 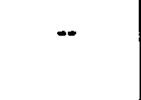 & $\begin{array}{l}\text { No attack, slight scaling at } \\
\text { crevice. }\end{array}$ & L25,L26,L27 \\
\hline $304 \mathrm{~L}$ & Vapor & 1029 & Creviced & $<0.07$ & -- & Trace of scaling at crevice. & L30,L29,L28 \\
\hline $304 \mathrm{~L}$ & Liquid & 1029 & Creviced & $<0.07$ & -. & $\begin{array}{l}\text { Slight scaling at crevice. } \\
\text { Very slight etching under scale. }\end{array}$ & $L 31, L 32, L 33$ \\
\hline $304 L$ & Vapor & 2855 & Creviced & 0.03 & 15 & Pitting under crevice on one sample. & L36,L35,L34 \\
\hline $304 L$ & Liquid & 2855 & Creviced & 0.29 & 62 & Deep pitting under crevice. & L37,L38,L39 \\
\hline $304 L$ & $\begin{array}{l}\text { Alt } \\
\text { Immersion }\end{array}$ & 2855 & Creviced & 0.43 & 41 & $\begin{array}{l}\text { Pitting on sample at interface. } \\
\text { Localized etching on others. }\end{array}$ & $L 40, L 41, L 42$ \\
\hline
\end{tabular}


Table 5.3 Summary Of Results Of Exposure Of Creviced Specimens Of Alloy 825 In Aerated Solution No. 20 At $90^{\circ} \mathrm{C}$.

\begin{tabular}{|c|c|c|c|c|c|c|c|}
\hline Alloy & Phase & $\begin{array}{l}\text { Test } \\
\text { Time } \\
\text { Hours }\end{array}$ & $\begin{array}{c}\text { Spocimen } \\
\text { Typo }\end{array}$ & $\begin{array}{c}\text { Corrosion } \\
\text { Rate } \\
\mu \mathrm{m} / \mathrm{yr}\end{array}$ & $\begin{array}{c}\text { Maximum } \\
\text { Pit Depth } \\
\mu \mathrm{m}\end{array}$ & Comments & Specimen \# \\
\hline 1825 & Vapor & 509 & Creviced & $<0.18$ & - & No aftack. & $124,123,122$ \\
\hline 1825 & Liquid & 509 & Creviced & $<0.14$ & - & $\begin{array}{l}\text { No attack, slight scaling at } \\
\text { crevice. }\end{array}$ & $125,126,127$ \\
\hline 1825 & Vapor & 1029 & Creviced & $<0.07$ & - & Trace of scaling at crevice. & $130,129,128$ \\
\hline 1825 & Liquid & 1029 & Croviced & $<0.07$ & - & $\begin{array}{l}\text { Slight scaling at crevice. } \\
\text { Very slight etching under scale. }\end{array}$ & $131,132,133$ \\
\hline 1825 & Vapor & 2856 & Creviced & $<0.002$ & - & No attack. & $136,135,134$ \\
\hline 1825 & Liquid & 2856 & Creviced & $<0.002$ & 10 & $\begin{array}{l}\text { Very slight etching at crevice. } \\
\text { Pitting on one sample. }\end{array}$ & \\
\hline 1825 & $\begin{array}{l}\text { Alt } \\
\text { Immersion }\end{array}$ & 2856 & Creviced & $<0.002$ & - & Very slight localized etching & \\
\hline
\end{tabular}


Table 5.4 Summary Of Results Of Electrochemical Measurements Performed In Aerated Solution No. 20 At $90^{\circ} \mathrm{C}$.

\begin{tabular}{|c|c|c|c|c|c|c|c|c|}
\hline \multirow[b]{2}{*}{ Alloy } & \multirow{2}{*}{$\begin{array}{l}\text { Time, } \\
\text { Hours }\end{array}$} & \multicolumn{2}{|c|}{$\begin{array}{l}\text { Polarization } \\
\text { Resistance } \\
\mathrm{kohm}-\mathrm{cm}^{2}\end{array}$} & \multicolumn{2}{|c|}{$\begin{array}{c}\text { Tafel } \\
\text { Slope } \\
\text { mV/decade }\end{array}$} & \multicolumn{2}{|c|}{$\begin{array}{c}\text { Corrosion Rate } \\
\mu \mu \mathrm{m} / \mathrm{yr}\end{array}$} & \multirow{2}{*}{$\frac{\begin{array}{c}E_{\infty x} \\
m V(S C E)\end{array}}{\text { Liquid }}$} \\
\hline & & Vapor & Liquid & $B_{2}$ & $B_{c}$ & Vapor & Liquid & \\
\hline 1825 & 171 & $12200^{(2)}$ & 688 & 272 & 69 & 0.02 & 0.35 & -189 \\
\hline 1825 & 365 & - & 10300 & 272 & 69 & - & 0.02 & -71 \\
\hline 1825 & 505 & 3590 & - & 272 & 69 & 0.07 & - & -111 \\
\hline 1825 & 672 & $142^{(2)}$ & $>290^{(b)}$ & 272 & 69 & 1.72 & $<0.84$ & -42 \\
\hline 1825 & 1011 & $5110^{(a)}$ & $>245^{(0)}$ & 272 & 69 & 0.05 & $<0.10$ & -57 \\
\hline 1825 & 1511 & $5780^{(a)}$ & $>1980^{(b)}$ & 272 & 69 & 0.04 & $<0.12$ & +14 \\
\hline 1825 & 2041 & $6440^{(2)}$ & $>2090^{(0)}$ & 272 & 69 & 0.04 & $<0.12$ & -21 \\
\hline 1825 & 2543 & 2840 & 7350 & 272 & 69 & 0.09 & $<0.03$ & -42 \\
\hline $304 \mathrm{~L}$ & 171 & $1060^{(a)}$ & 1870 & 372 & 76 & 0.27 & 0.15 & -31 \\
\hline $304 \mathrm{~L}$ & 335 & $1140^{(2)}$ & 10800 & 372 & 76 & 0.25 & 0.0 & -32 \\
\hline 304L & 503 & 231 & 3110 & 372 & 76 & 1.25 & 0.09 & -20 \\
\hline $304 \mathrm{~L}$ & 671 & - & $>262^{(b)}$ & 372 & 76 & - & $<1.10$ & -20 \\
\hline $304 \mathrm{~L}$ & 1008 & $313^{(2)}$ & $>3400^{(0)}$ & 372 & 76 & 0.92 & $<0.08$ & -20 \\
\hline $304 \mathrm{~L}$ & 1508 & $2590^{(2)}$ & $>1510^{(b)}$ & 372 & 76 & 0.11 & $<0.18$ & -19 \\
\hline $304 \mathrm{~L}$ & 2042 & $8840^{(a)}$ & $>2540^{(0)}$ & 372 & 76 & 0.03 & $<0.11$ & -13 \\
\hline 304L & 2543 & 7020 & 7090 & 372 & 76 & 0.04 & 0.04 & -42 \\
\hline
\end{tabular}
(a) Manually
(b) By Electrochemical Impedance Spectroscopy 


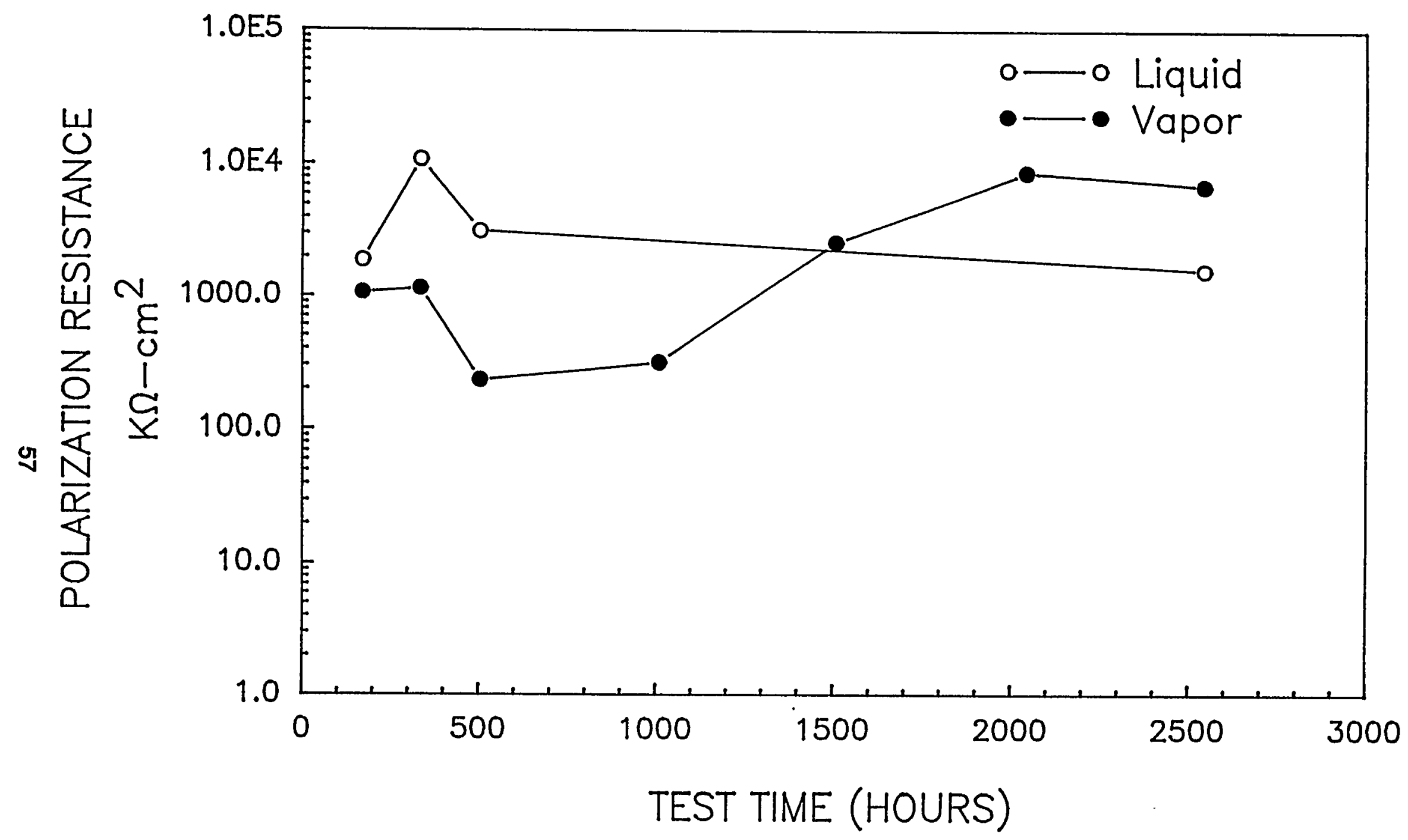

Figure 5.1 Polarization Resistance As A Function Of Test Time For Specimens Of Alloy 304L In The Liquid And Vapor Phase Of Aerated Solution No. 20 At $90^{\circ} \mathrm{C}$ (Prior $\mathrm{To}_{2} \mathrm{O}_{2}$ Additions Or Following $\mathrm{H}_{2} \mathrm{O}_{2}$ Decay (2500 Hour Data)). 


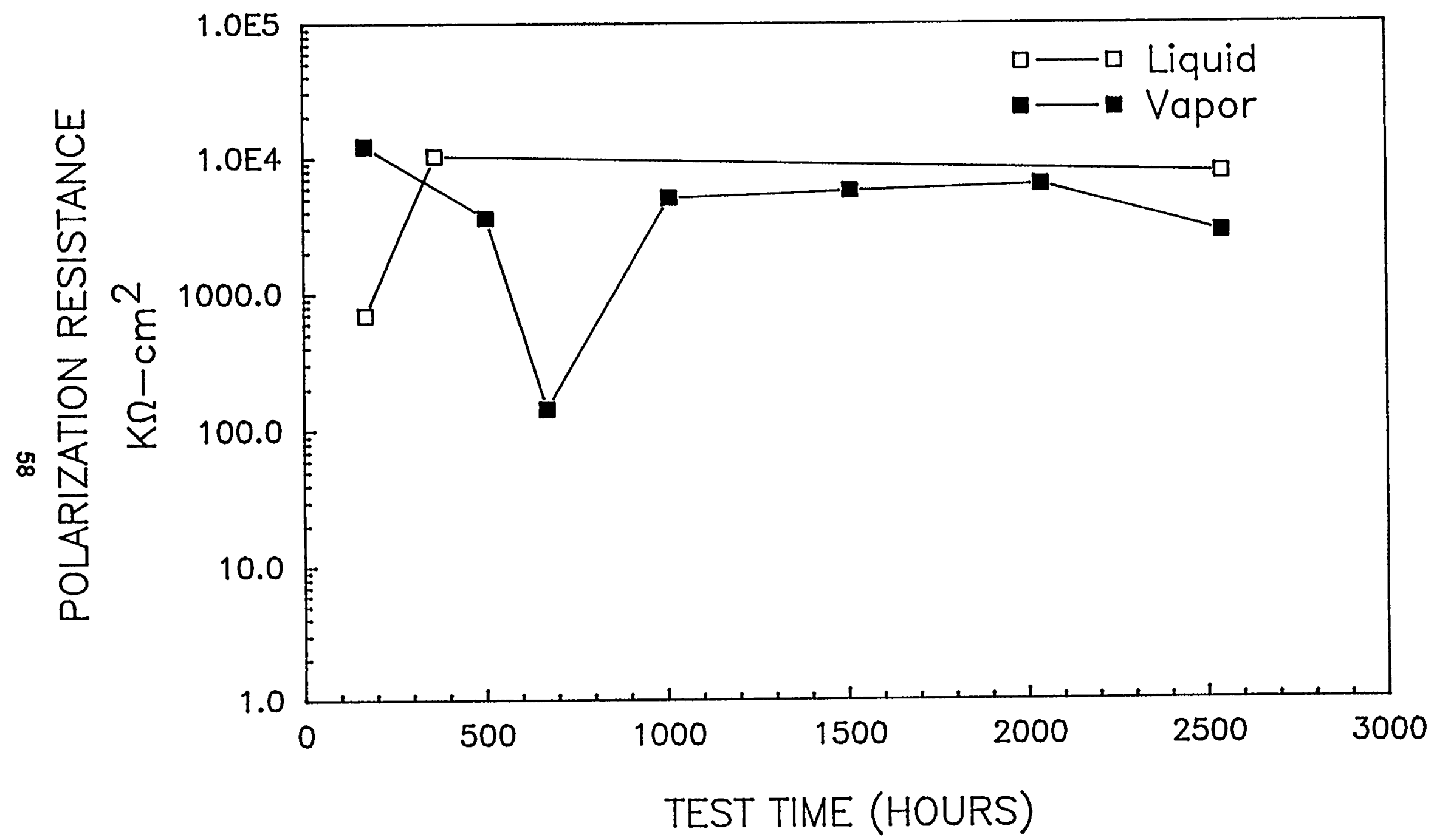

Figure 5.2 Polarization Resistance As A Function Of Test Time For Specimens Of Alloy 825 In The Liquild And Vapor Phase Of Aerated Solution No. 20 At $90^{\circ} \mathrm{C}$ (Prior To $\mathrm{H}_{2} \mathrm{O}_{2}$ Additions Or Following $\mathrm{H}_{2} \mathrm{O}_{2}$ Decay (2500 Hour Data)). 


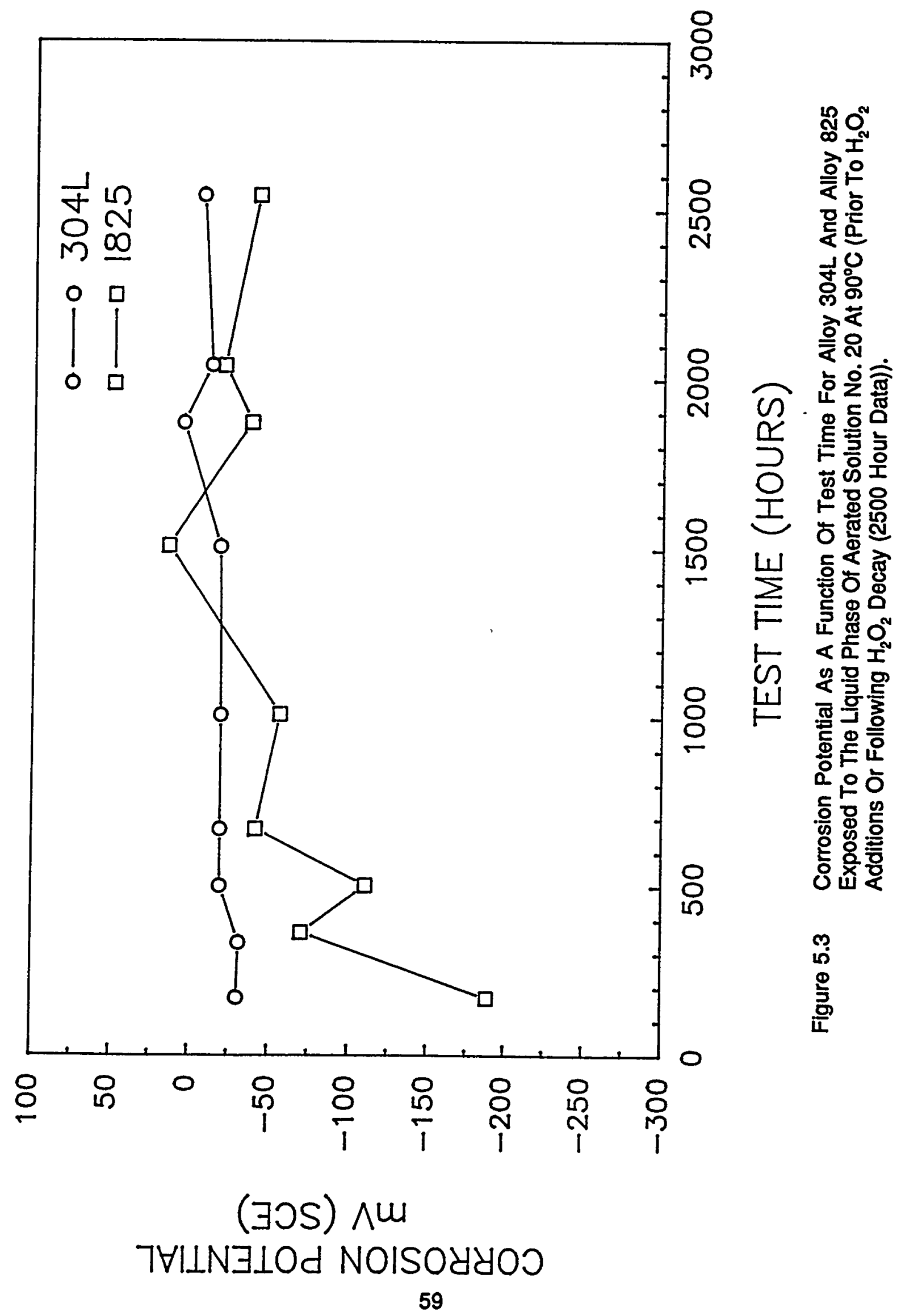




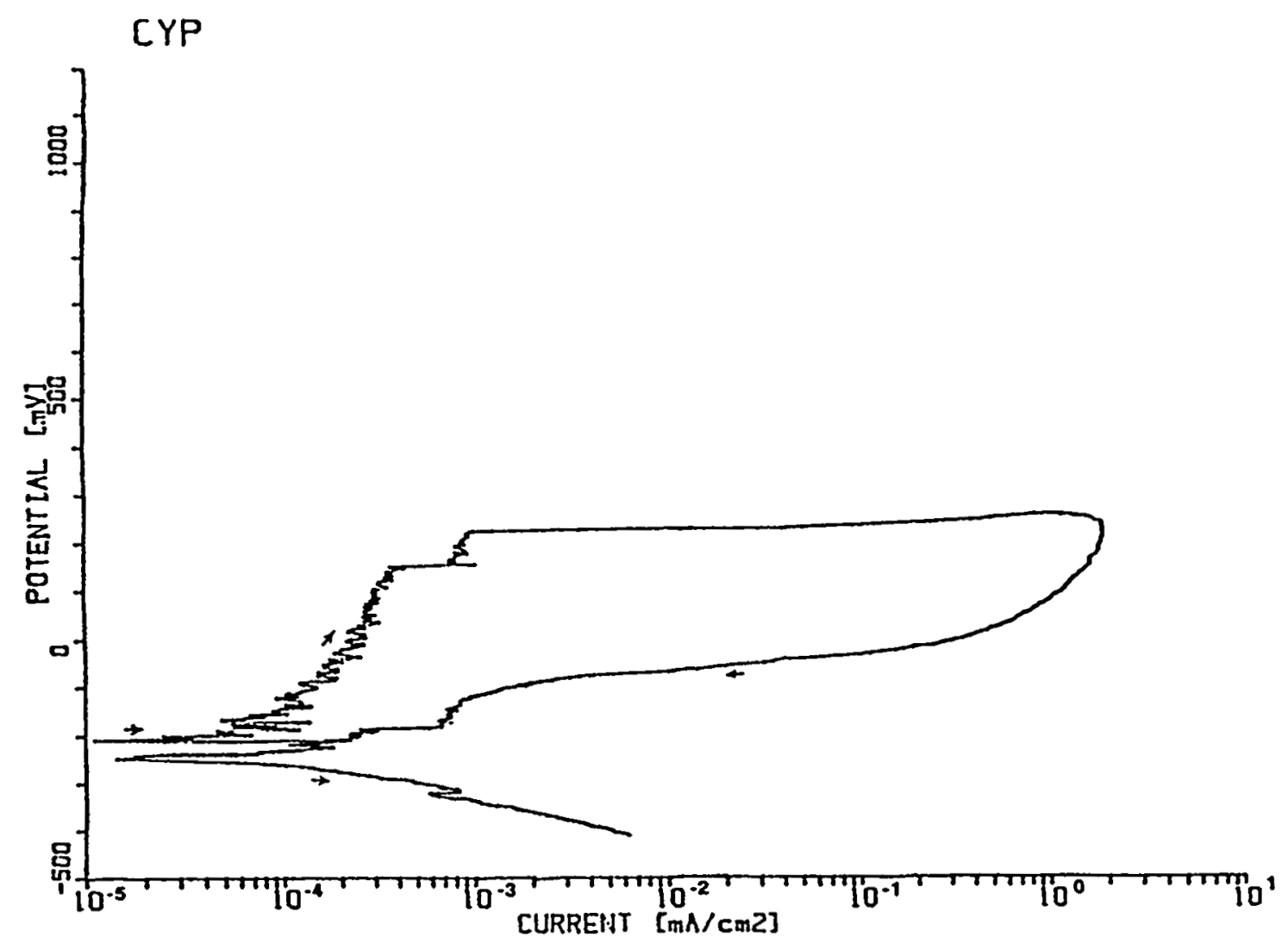

Figure 5.4 Polarization Curve For Alloy $304 \mathrm{~L}$ in Test Solution No. 20 At $90^{\circ} \mathrm{C}$.

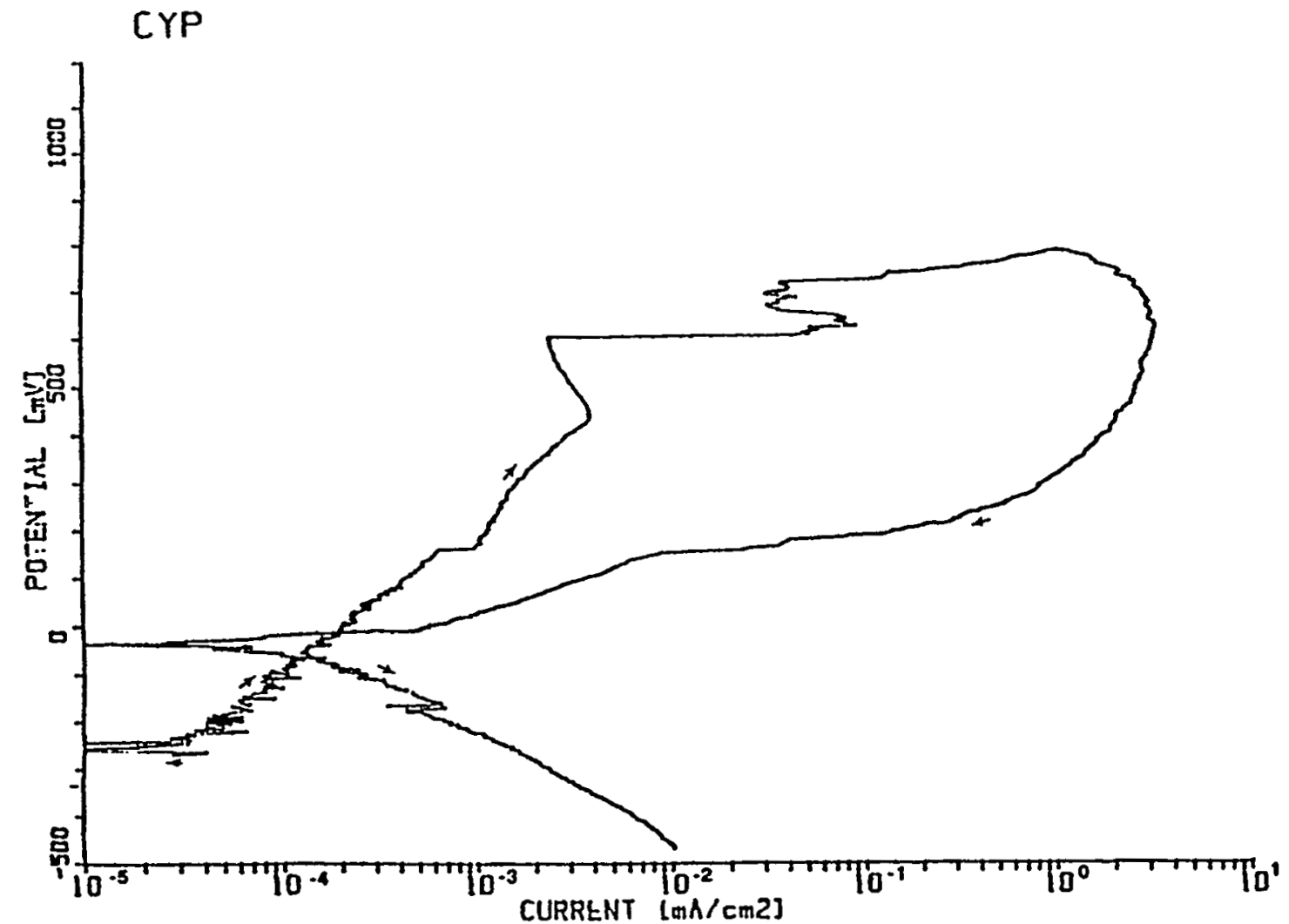

Figure 5.5 Polarization Curve For Alloy 825 In Test Solution No. 20 At $90^{\circ} \mathrm{C}$. 
additions). As anticipated, Alloy 825 was found to be more resistant to pitting than Alloy $304 \mathrm{~L}$. The vapor monitors showed no visible attack for either alloy.

Both immersion tests were extended beyond the 2000 hour exposure time originally planned due to the low corrosion rates observed and the absence of significant localized corrosion. In an attempt to promote pitting of the specimens, by moving the corrosion potential into the pitting range, $200 \mathrm{ppm}$ hydrogen peroxide $\left(\mathrm{H}_{2} \mathrm{O}_{2}\right)$ was added to each of the test kettles after approximately 2200 hours of exposure for a period of seven working days and the change in potential was monitored. Hydrogen peroxide is expected to be generated as a result of radiolysis of the groundwater in the Tuff Repository. Following each $\mathrm{H}_{2} \mathrm{O}_{2}$ addition, a noble potential spike occurred, followed by a potential decline. The potential decline was quite rapid for Alloy 825, but somewhat slower for Alloy 304L. In an attempt to slow the potential decay, larger doses of $\mathrm{H}_{2} \mathrm{O}_{2}$ were added over the next seven day period. Figures 5.6 and 5.7 illustrate the changes in the corrosion potentials as a function of test time for each of the two alloys.

Alloy 825 appeared to catalyze the $\mathrm{H}_{2} \mathrm{O}_{2}$ degradation as shown by the sharp decline in potential, even at very high $\mathrm{H}_{2} \mathrm{O}_{2}$ concentrations. Alloy $304 \mathrm{~L}$ showed a much narrower range of potential change and the $\mathrm{H}_{2} \mathrm{O}_{2}$ appeared to degrade much slower. Effervescence from the $\mathrm{H}_{2} \mathrm{O}_{2}$ was also observed in the kettle containing Alloy $304 \mathrm{~L}$ considerably longer than in the kettle containing Alloy 825. The hydrogen peroxide was allowed to degrade over the weekend following the $4800 \mathrm{ppm}$ addition before terminating the test.

After 2855 hours of exposure, the corrosion potentials were again compared to $E_{p l t}$ and $E_{p r o s}$ for each of the alloys. Potentials for Alloy 825 remained below $\mathrm{E}_{\text {prot }}$ prior to the $\mathrm{H}_{2} \mathrm{O}_{2}$ additions. The $\mathrm{H}_{2} \mathrm{O}_{2}$ raised the potential above $\mathrm{E}_{\text {prot }}(+90 \mathrm{mV})$, but fell far short of $\mathrm{E}_{\text {pit }}(+690 \mathrm{mV})$. Specimen evaluation showed only a few shallow pits on one specimen in the liquid phase and very slight etching on the remaining liquid-phase specimens.

The corrosion potentials for Alloy $304 \mathrm{~L}$ fell between $E_{p l t}(+400 \mathrm{mV})$ and $E_{\text {prot }}(-150 \mathrm{mV})$ during the entire 2855 hours of exposure. Although the $\mathrm{H}_{2} \mathrm{O}_{2}$ increased the potential slightly, it was insufficient to raise it above $E_{\text {pit }}$. Corrosion potentials that fall between $E_{p i t}$ and $E_{p r o t}$ suggest that pitting could possibly occur over an extended period of time. Specimen examination confirmed very deep pits under the crevices on specimens in the liquid phase for Alloy 304L.

The polarization resistance of each alloy in the liquid was determined five minutes after each incremental $\mathrm{H}_{2} \mathrm{O}_{2}$ addition to estimate corrosion rate. The results of these measurements are presented in Table 5.5 and graphically in Figure 5.8. These data show a systematic decrease in polarization resistance, indicating an increase in corrosion rate, with increasing $\mathrm{H}_{2} \mathrm{O}_{2}$ concentration. However, it should be cautioned that the decrease in polarization resistance may be associated with electrochemical reactions in solution other than corrosion.

\subsubsection{Stress-Corrosion Cracking}

Constant strain (U-bend) specimens were also evaluated at the end of the exposure. No SCC was observed for any of the Alloy 825 specimens. SCC was observed in specimens of Alloy $304 \mathrm{~L}$ that were in the vapor phase and possibly in one of the alternate-immersion specimens. 


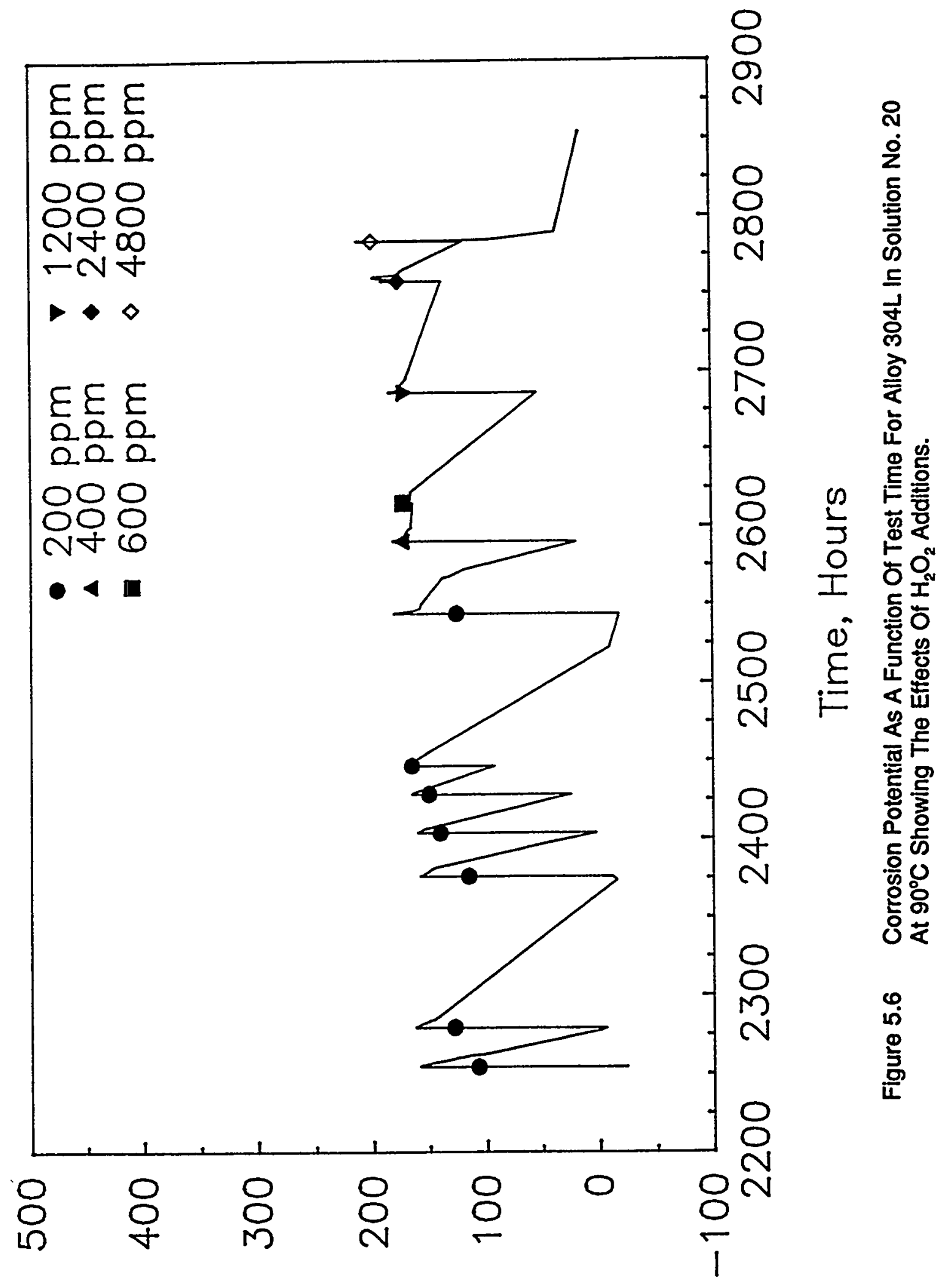

$(\exists O S) \wedge M$ ' 


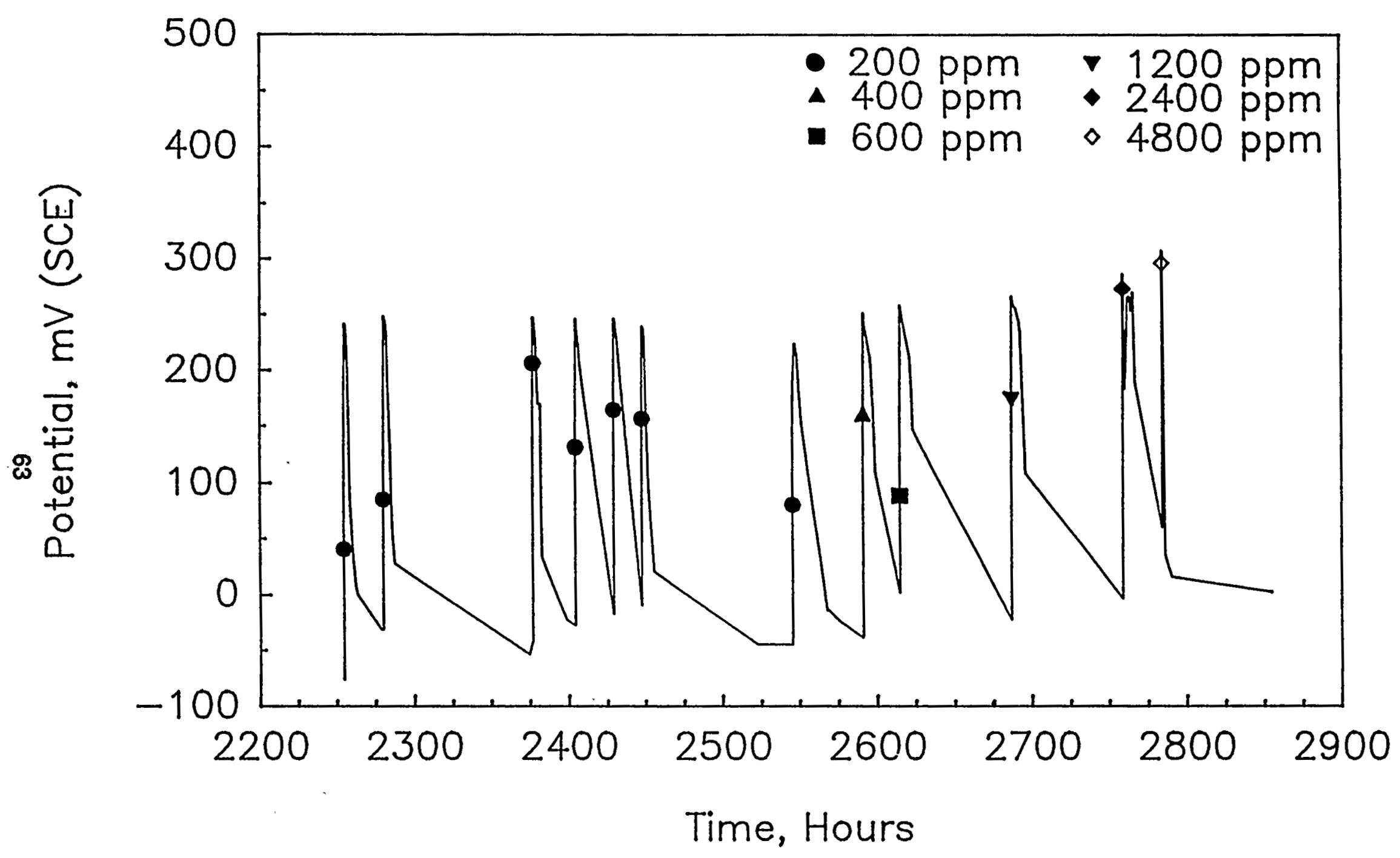

Figure 5.7 Corrosion Potential As A Function of Test Time For Alloy 825 in Solution No. 20 At $90^{\circ} \mathrm{C}$ Showing The Effects Of $\mathrm{H}_{2} \mathrm{O}_{2}$ Additions. 
Table 5.5 Sumary Of Results Of Electrochemical Measurements Five Minutes Following $\mathrm{H}_{2} \mathrm{O}_{2}$ Additions To Aerated Solution No. 20 At $90^{\circ} \mathrm{C}$.

\begin{tabular}{|c|c|c|c|c|c|}
\hline Alloy & Hours & $\begin{array}{c}\mathrm{H}_{2} \mathrm{O}_{2} \\
\mathrm{ppm}\end{array}$ & $\begin{array}{c}E_{c o r} \\
m V(S C E)\end{array}$ & $\begin{array}{c}\text { Polarization } \\
\text { Resistance } \\
\text { kohm-cm² }\end{array}$ & $\begin{array}{c}\text { Corrosion } \\
\text { Rate } \\
\mu \mathrm{m} / \mathrm{yr}\end{array}$ \\
\hline 1825 & 2544 & 0 & -61 & 7850 & 0.03 \\
\hline 1825 & 2544 & 200 & +181 & 3980 & 0.06 \\
\hline 1825 & 2590 & 400 & +251 & 309 & 0.79 \\
\hline 1825 & 2614 & 600 & +258 & 310 & 0.79 \\
\hline 1825 & 2686 & 1200 & +264 & 206 & 1.19 \\
\hline 1825 & 2758 & 2400 & +286 & 60.3 & 4.04 \\
\hline 1825 & 2784 & 4800 & +306 & 26.6 & 9.17 \\
\hline $304 \mathrm{~L}$ & 2544 & 0 & +3 & 7090 & 0.04 \\
\hline $304 \mathrm{~L}$ & 2544 & 200 & +181 & 1580 & 0.18 \\
\hline 304L & 2590 & 400 & +181 & 483 & 0.60 \\
\hline $304 L$ & 2613 & 600 & +177 & 328 & 0.88 \\
\hline $304 \mathrm{~L}$ & 2685 & 1200 & +184 & 249 & 1.16 \\
\hline $304 L$ & 2727 & 2400 & +191 & 83.7 & 3.44 \\
\hline 304L & 2783 & 4800 & +212 & 43.8 & 6.58 \\
\hline
\end{tabular}




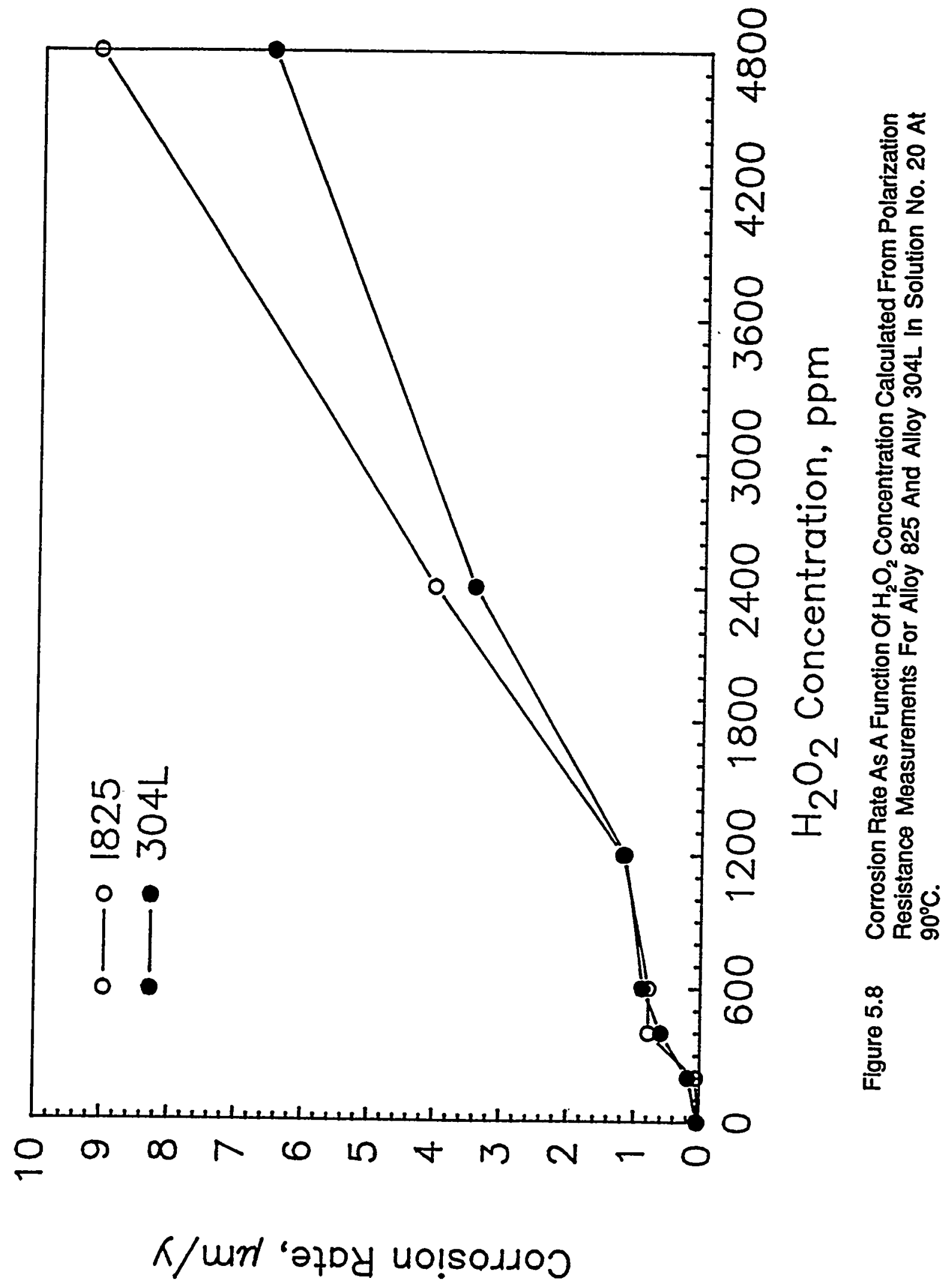


No cracks were visible at $30 \mathrm{X}$ magnification in liquid-phase specimens. Pitting and etching was also severe on specimens that exhibited cracking. Metallography was performed on one of the specimens that exhibited SCC.

Metallographic analysis showed the SCC to be transgranular in nature. Most of the cracks were found to originate from deep pits that had initiated on stressed portions of the U-bends. Photographs of the SCC at 7X and 250X magnification are shown in Figures 5.9 and 5.10 respectively. One possible explanation for pitting and cracking of only vapor-phase specimens may be related to the availability of the oxidant $\left(\mathrm{H}_{2} \mathrm{O}_{2}\right)$ to the specimen surface through a condensed layer in the vapor phase. 


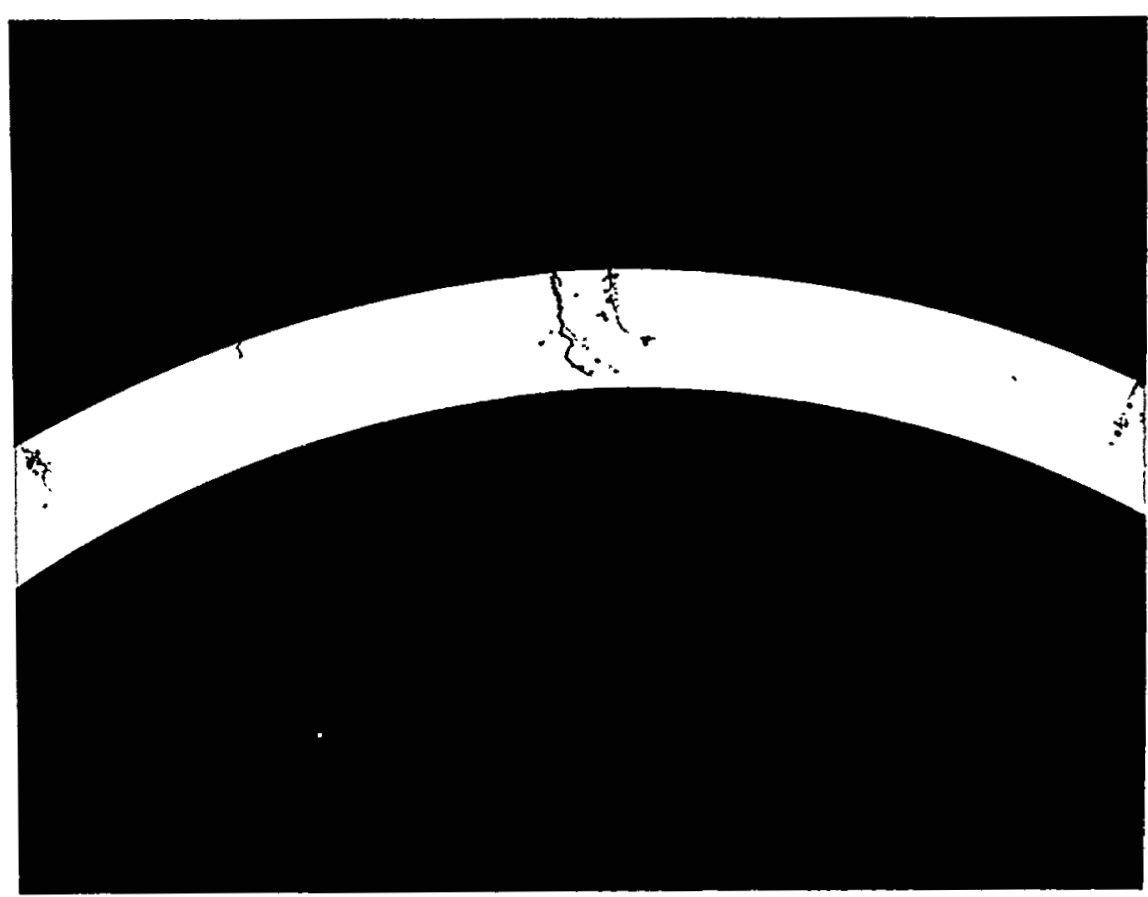

Figure 5.9 Photomicrograph Of Alloy 304L U-bend Specimen Following 2855 Hours Of Exposure To Solution No. 20 (With $\mathrm{H}_{2} \mathrm{O}_{2}$ Additions) At $90^{\circ} \mathrm{C}$ Showing StressCorrosion Cracking; 7X Magnification.

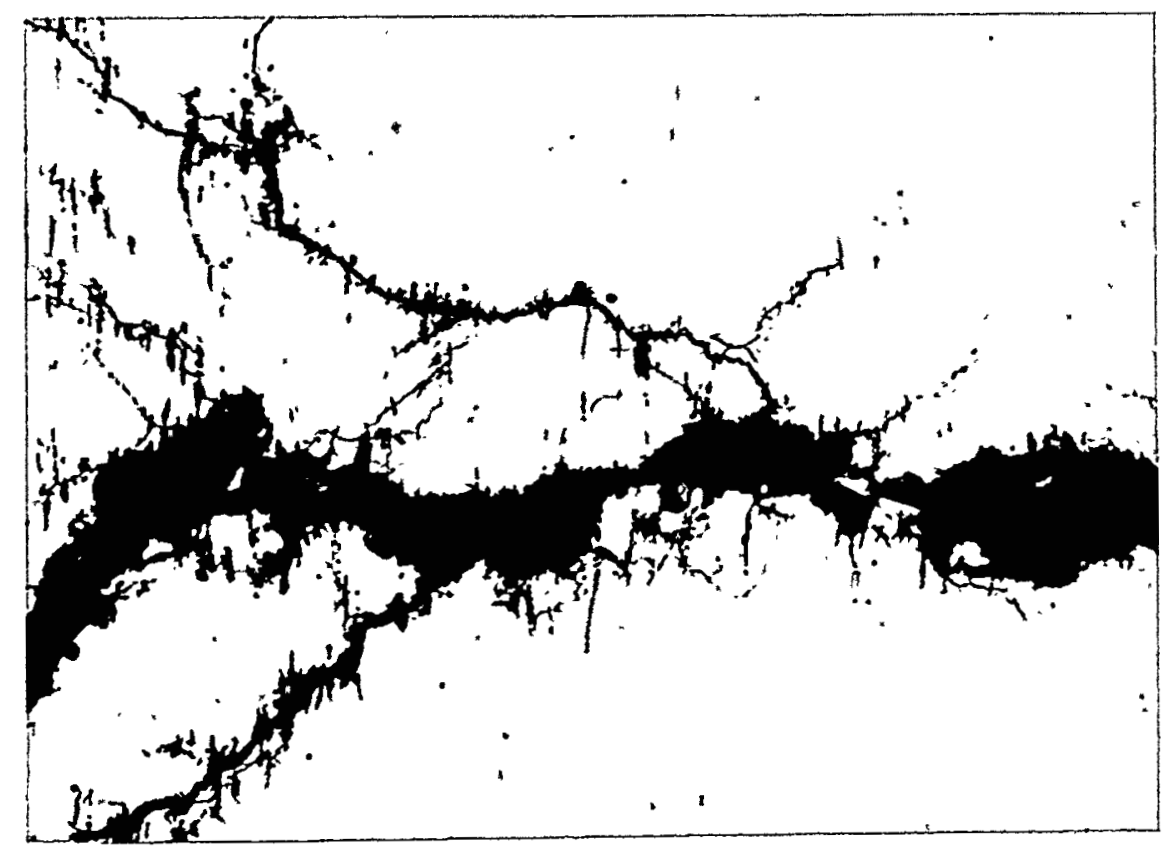

Figure 5.10 Photomicrograph Of Alloy 304L U-Bend Specimen Following 2855 Hours Of Exposure To Solution No. 20 (With $\mathrm{H}_{2} \mathrm{O}_{2}$ Additions) At $90^{\circ} \mathrm{C}$ Showing Transgranular Stress-Corrosion Cracking; 250X Magnification. 


\section{CORROSION BEHAVIOR IN AN ACTIVE CORROSION ENVIRONMENT}

\subsection{Copper-Base Alloys}

\subsubsection{General Corrosion}

Exposure tests of 2014 hours were performed on Alloy CDA 102 and Alloy CDA 715 in aerated Solution No. 7 at $90^{\circ} \mathrm{C}$. Solution No. 7 was selected from the experimental test matrix where it was found to be an active corrosion environment for the copper-base alloys based on potentiodynamic polarization tests. The composition of Solution No. 7 is given in Table 6.1. The data in Table 6.1 show that Solution No. 7 was high in chloride and oxalic acid and had a low pH. A summary of the weight-loss and optical-examination data is given in Table 6.2. In the vapor phase, these data were comparable to those observed for simulated $\mathrm{J}-13$ well water while the rates in the liquid were several orders of magnitude higher in Solution No. 7 than in the simulated $\mathrm{J}-13$ well water. Severe crevice corrosion and pitting were also observed in Solution No. 7 . It is interesting to note that the crevice corrosion was confined primarily to the open regions (adjacent to the tight crevices) where deposits had collected.

Data from the electrochemical measurements of Alloy CDA 102 and Alloy CDA 715 are summarized in Table 6.3 and exhibited graphically in Figures 6.1 through 6.3. Figure 6.1 shows that the vapor-phase polarization resistance (PR) for CDA 102 was about two orders of magnitude higher than the liquid-phase PR, indicating a much higher corrosion rate in the liquid. Similar trends were observed for CDA 715 (Figure 6.2) but PR values for CDA 715 were higher than those of CDA 102. The PR values were converted to general corrosion rates using the SternGeary equation and Faraday's Law and those values are tabulated in Table 6.3. Comparison of the electrochemical data in Table 6.3 with actual weight-loss data for the test (Table 6.2) indicates that the electrochemistry consistently overestimate the general corrosion rate of CDA 102 by about a factor of two for the liquid-phase exposures and somewhat more than that for the vaporphase exposures. PR estimates for the general corrosion rate of CDA 715 were somewhat better than those for CDA 102 but, in general, PR overestimated the corrosion rates for CDA 715 as well. This behavior is typical for PR measurements and is probably a consequence of the presence of spurious (non-corrosion) electrochemical reactions in the test electrolyte.

\subsubsection{Localized Corrosion}

For Alloy CDA 102, the vapor-phase specimens exhibited moderate etching. The etching was much more severe at the edges of the crevices. The vapor monitor was tarnished, but showed negligible attack. Both the alternate immersion and the liquid-phase specimens exhibited severe pitting and etching that was primarily concentrated in the creviced region. The precisionmachined rod used to evaluate corrosion at the vapor-liquid interface showed severe attack. Heavy etching was observed in both the liquid and vapor phases with severe metal loss; up to $0.762 \mathrm{~mm}$ of loss in the rod's diameter for Alloy CDA 102. 
Table 6.1 Chemical Composition Of J-13 Well Water And Solution No. 7 From The Experimental Test Matrix.

\begin{tabular}{|c|c|c|c|}
\hline $\begin{array}{l}\text { Environmental } \\
\text { Species }\end{array}$ & $\begin{array}{c}\mathrm{J}-13 \text { Well Water } \\
\mathrm{mg} / \mathrm{l}\end{array}$ & $\begin{array}{c}\text { Simulated } \\
\mathrm{J}-13 \text { Well Water } \\
\mathrm{mg} / \mathrm{l}\end{array}$ & $\begin{array}{c}\text { Solution No. } 7 \\
\mathrm{mg} / \mathrm{l}\end{array}$ \\
\hline $\mathrm{pH}$ & 7.6 & $7.0 \pm 0.2$ & 5.0 \\
\hline $\mathrm{SiO}_{2}$ & 58 & 64.2 & 215 \\
\hline $\mathrm{HCO}_{3}^{-}$ & 125 & 121 & 0.4 \\
\hline$F^{-}$ & 2.2 & 1.7 & 0.04 \\
\hline $\mathrm{Cl}^{-}$ & 6.9 & 6.4 & 1000 \\
\hline $\mathrm{NO}_{3}^{-}$ & 9.6 & 12.4 & 0.2 \\
\hline $\mathrm{SO}_{4}{ }^{2-}$ & 18.7 & 19.2 & * \\
\hline $\mathrm{NO}_{2}^{-}$ & - & - & 0.0 \\
\hline $\mathrm{H}_{2} \mathrm{O}_{2}$ & - & - & 0.0 \\
\hline $\mathrm{Al}^{3+}$ & 0.012 & - & 0.0004 \\
\hline $\mathrm{Fe}^{2+}$ & 0.006 & - & 0.0 \\
\hline $\mathrm{Ca}^{2+}$ & 12.5 & 12.0 & 0.8 \\
\hline $\mathrm{Mg}^{2+}$ & 1.9 & 1.7 & 0.8 \\
\hline $\mathrm{K}^{+}$ & 5.1 & 5.5 & 0.08 \\
\hline $\mathrm{Na}^{+}$ & 44 & 46 & * \\
\hline $\mathrm{PO}_{4}{ }^{3-}$ & 0.12 & - & 2.0 \\
\hline Oxalic Acid & - & - & 172 \\
\hline
\end{tabular}

${ }^{*} \mathrm{Na}^{+}$and $\mathrm{SO}_{4}{ }^{2-}$ were used to balance the composition. 
Table 6.2 Summary Of Results Of 2014 Hour Exposures Of Creviced Specimens Of The Copper-Base Alloys in Aerated Solution No. 7 At $90^{\circ} \mathrm{C}$.

\begin{tabular}{|c|c|c|c|c|c|c|}
\hline Alloy & Phase & $\begin{array}{l}\text { Test } \\
\text { Time } \\
\text { Hours }\end{array}$ & $\begin{array}{c}\text { Corrosion } \\
\text { Rate } \\
\mu \mathrm{m} / \mathrm{yr}\end{array}$ & $\begin{array}{c}\text { Maximum } \\
\text { Pit Depth } \\
\mu \mathrm{m}\end{array}$ & Comments & Specimen \# \\
\hline CDA 102 & Vapor & 503 & 5.90 & 9 & Light etching and tamishing & $611,601,591$ \\
\hline CDA 102 & Vapor & 1009 & 2.57 & $<6$ & Moderate etching & $671,661,651$ \\
\hline CDA 102 & Vapor & 2014 & 1.63 & $<6$ & Moderate etching & $731,721,711$ \\
\hline CDA 102 & Liquid & 503 & 70.5 & 78 & Severe pitting and etching & $621,631,641$ \\
\hline CDA 102 & Liquid & 1009 & 44.2 & 114 & Severe pitting and etching; crevice corrosion & $681,691,701$ \\
\hline CDA 102 & Liquid & 2014 & 24.11 & 147 & Severe pitting and etching; crevice corrosion & $741,751,761$ \\
\hline CDA 102 & $\begin{array}{l}\text { Alt } \\
\text { Immersion }\end{array}$ & 2014 & 22.26 & 100 & $\begin{array}{l}\text { Moderate etching and heavy localized } \\
\text { etching; crevice corrosion }\end{array}$ & $771,781,791$ \\
\hline CDA 715 & Vapor & 505 & 0.68 & 10 & Moderate etching; a few shallow pits & $3 A, 2 A, 1 A$ \\
\hline CDA 715 & Vapor & 1009 & 0.60 & 21 & Light etching; several shallow pits & 9A,8A,7A \\
\hline CDA 715 & Vapor & 2014 & 0.33 & 30 & $\begin{array}{l}\text { Heavy localized etching and pitting; crevice } \\
\text { corrosion }\end{array}$ & $18 \mathrm{~A}, 17,16 \mathrm{~A}$ \\
\hline CDA 715 & Liquid & 505 & 32.9 & 76 & Severe etching and crevice corrosion & $4 A, 5 A, 6 A$ \\
\hline CDA 715 & Liquid & 1009 & 20.7 & 51 & Severe etching and crevice corrosion & $13 A, 14 A, 15 A$ \\
\hline CDA 715 & Liquid & 2014 & 12.7 & 98 & Severe etching and crevice corrosion & $20 A, 21 A, 22 A$ \\
\hline CDA 715 & $\begin{array}{c}\text { Alt } \\
\text { Immersion }\end{array}$ & 2014 & 10.6 & 49 & Severe elching and crevice corrosion & $23 A, 24 A, 31 A$ \\
\hline
\end{tabular}


Table 6.3 Summary Of Results Of Electrochemical Measurements Performed On CopperBase Alloy Specimens In Aerated Solution No. 7 At $90^{\circ} \mathrm{C}$.

\begin{tabular}{|c|c|c|c|c|c|c|c|c|}
\hline \multirow[b]{2}{*}{ Alloy } & \multirow{2}{*}{$\begin{array}{l}\text { Time, } \\
\text { Hours }\end{array}$} & \multicolumn{2}{|c|}{$\begin{array}{l}\text { Polarization } \\
\text { Resistance } \\
\text { kohm - } \mathrm{cm}^{2}\end{array}$} & \multicolumn{2}{|c|}{$\begin{array}{c}\text { Tafel } \\
\text { Slope } \\
\text { mV/decade }\end{array}$} & \multicolumn{2}{|c|}{$\begin{array}{c}\text { Corrosion Rate } \\
\mu \mathrm{m} / \mathrm{yr}\end{array}$} & \multirow{2}{*}{$\frac{\begin{array}{c}E_{\text {cor }} \\
m V(S C E)\end{array}}{\text { Liquid }}$} \\
\hline & & Vapor & Liquid & $\mathrm{B}_{\mathrm{a}}$ & $\mathrm{B}_{\mathrm{c}}$ & Vapor & Liquid & \\
\hline 102 & 336 & 1100 & 2.71 & 74 & 521 & 0.59 & 241 & -106 \\
\hline 102 & 502 & 465 & 3.93 & 74 & 521 & 1.41 & 167 & -144 \\
\hline 102 & 669 & 829 & 5.10 & 74 & 521 & 0.79 & 128 & -119 \\
\hline 102 & 1004 & 470 & 2.91 & 74 & 521 & 1.39 & 225 & -233 \\
\hline 102 & 1344 & 1090 & 3.48 & 74 & 521 & 0.60 & 188 & -212 \\
\hline 102 & 1680 & 922 & 8.28 & 74 & 521 & 0.71 & 79 & -249 \\
\hline 102 & 2012 & 1700 & 8.18 & 74 & 521 & 0.39 & 80 & -207 \\
\hline 715 & 336 & 8950 & 14.15 & 98 & 1318 & 0.08 & 48.6 & -96 \\
\hline 715 & 501 & 15800 & 11.82 & 98 & 1318 & 0.04 & 58.2 & -54 \\
\hline 715 & 670 & 1640 & 60.04 & 98 & 1318 & 0.42 & 11.5 & -113 \\
\hline 715 & 1006 & $N^{*}$ & 78.18 & 98 & 1318 & $N D^{*}$ & 8.8 & -74 \\
\hline 715 & 1345 & 2310 & 35.25 & 98 & 1318 & 0.30 & 19.5 & -117 \\
\hline 715 & 1681 & 9490 & 70.79 & 98 & 1318 & 0.07 & 9.7 & -120 \\
\hline 715 & 2013 & $N D^{\star}$ & 62.34 & 98 & 1318 & ND* & 11.0 & -130 \\
\hline
\end{tabular}

*ND - Not Determined 


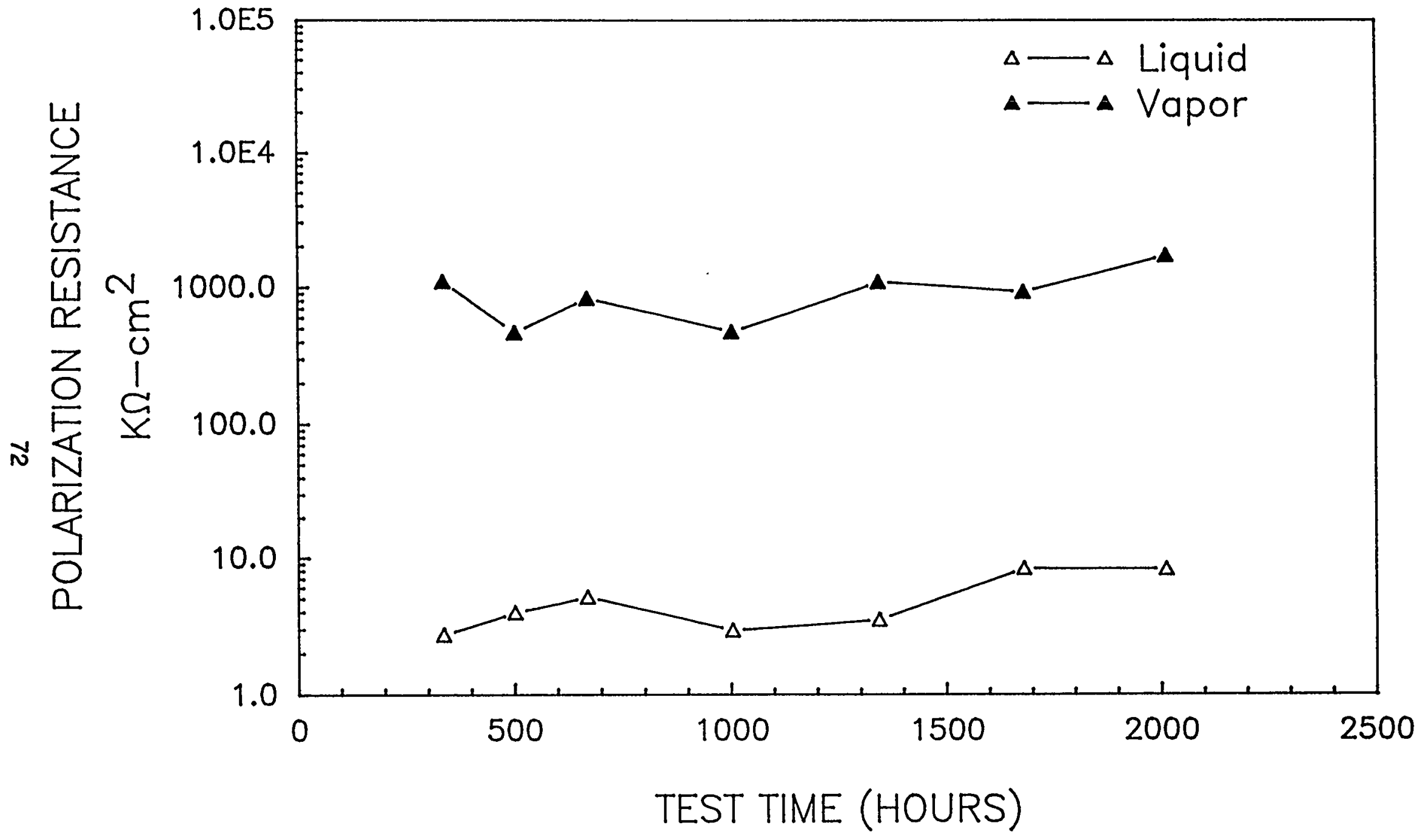

Figure 6.1 Polarization Resistance As A Function Of Test Time For Specimens Of Alloy CDA 102 in The Liquid And Vapor Phase Of Aerated Solution No. 7 At $90^{\circ} \mathrm{C}$. 


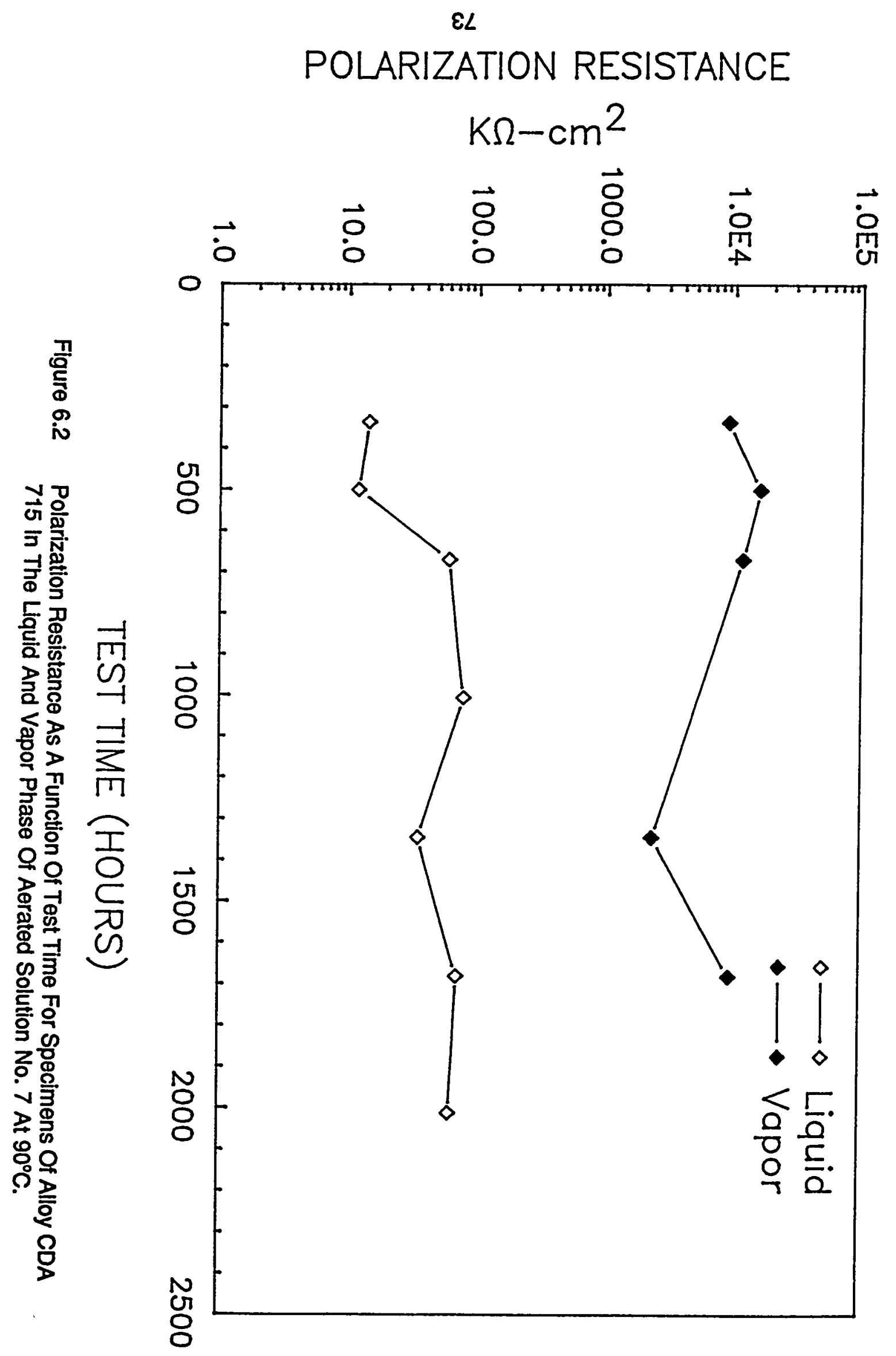




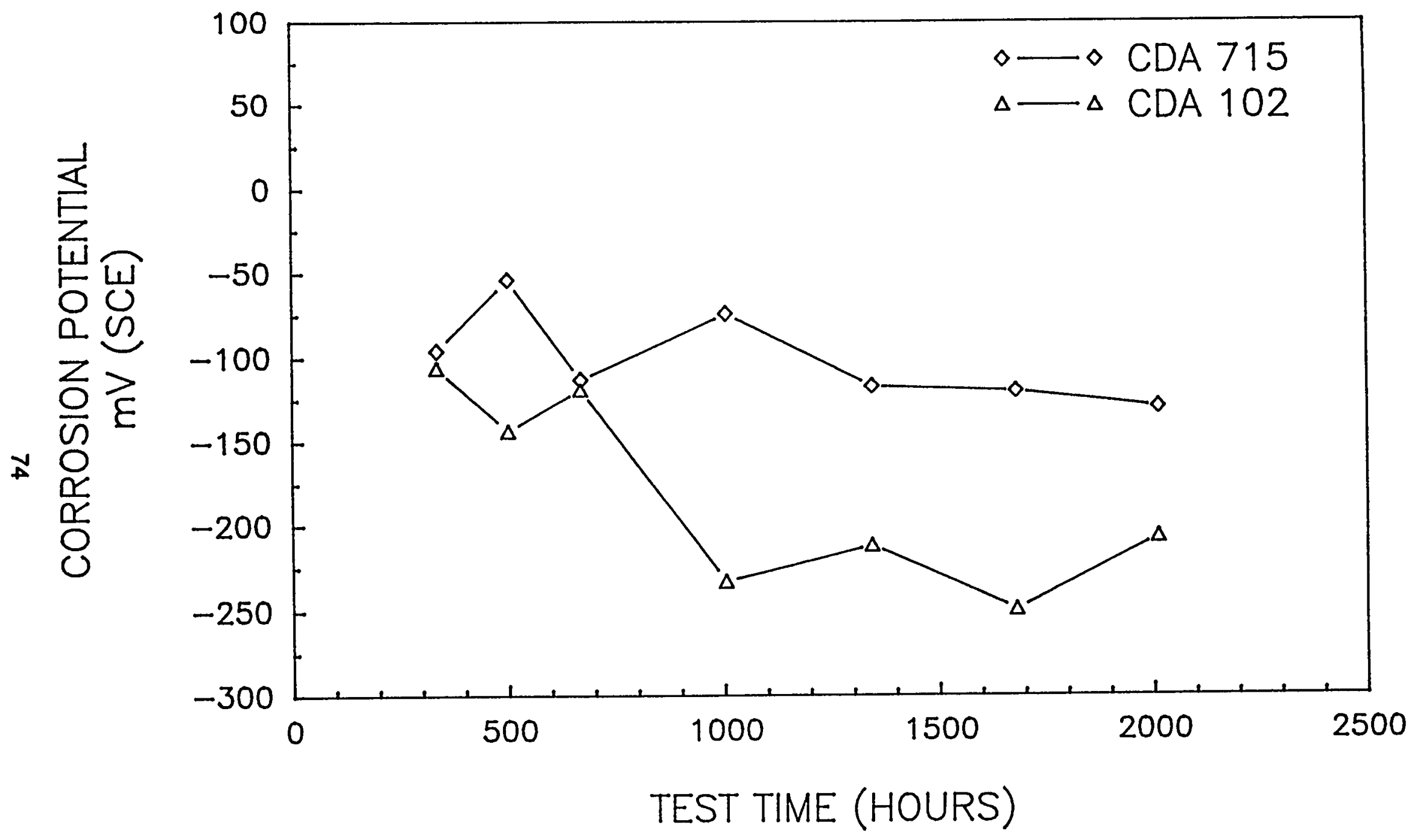

Figure 6.3 Corrosion Potential As A Function Of Test Time For Alloy CDA 102 And Alloy CDA 715 Exposed To The Liquid Phase Of Aerated Solution No. 7 At $90^{\circ} \mathrm{C}$. 
For Alloy CDA 715, vapor-phase specimens exhibited moderate etching and pitting. The pitting and etching were much more severe in the creviced region. The vapor monitor also showed numerous, shallow, pit-like depressions whose depths measured less than $10 \mu \mathrm{m}$. The precisionmachined rod further indicated heavy pitting and etching at the vapor-liquid contact. The portion of the rod exposed to the liquid phase exhibited numerous large, deep pits. The liquid-phase specimens also exhibited severe etching and pitting, especially in the creviced region.

The cyclic potentiodynamic polarization (CPP) curves for these alloys in Solution No. 7 are not fully consistent with the results of these exposure tests; the polarization curves are shown in Figures 6.4 and 6.5. These curves are characteristic of active behavior with no hysteresis or other indications of localized forms of corrosion. The localized corrosion observed in the exposure tests may be a consequence of the occurrence of differential aeration cells on the specimens as a result of the presence of the crevice washers and deposits on the specimens. Alternatively, the discrepancy may be attributed to the fact that the polarization curves do not represent steady-state behavior for the copper-base alloy-environment system. Results of the Task 2 CPP work are consistent with this interpretation.

\subsubsection{Stress-Corrosion Cracking}

Constant strain (U-bend) specimens were also evaluated at the end of the exposure. No SCC was observed for Alloy CDA 715 after 503, 1009, or 2014 hours of exposure although etching and pitting was observed in both the vapor and liquid phases. No SCC was observed for Alloy CDA 102 after the exposure periods although the liquid-phase specimens exhibited heavy etching. 


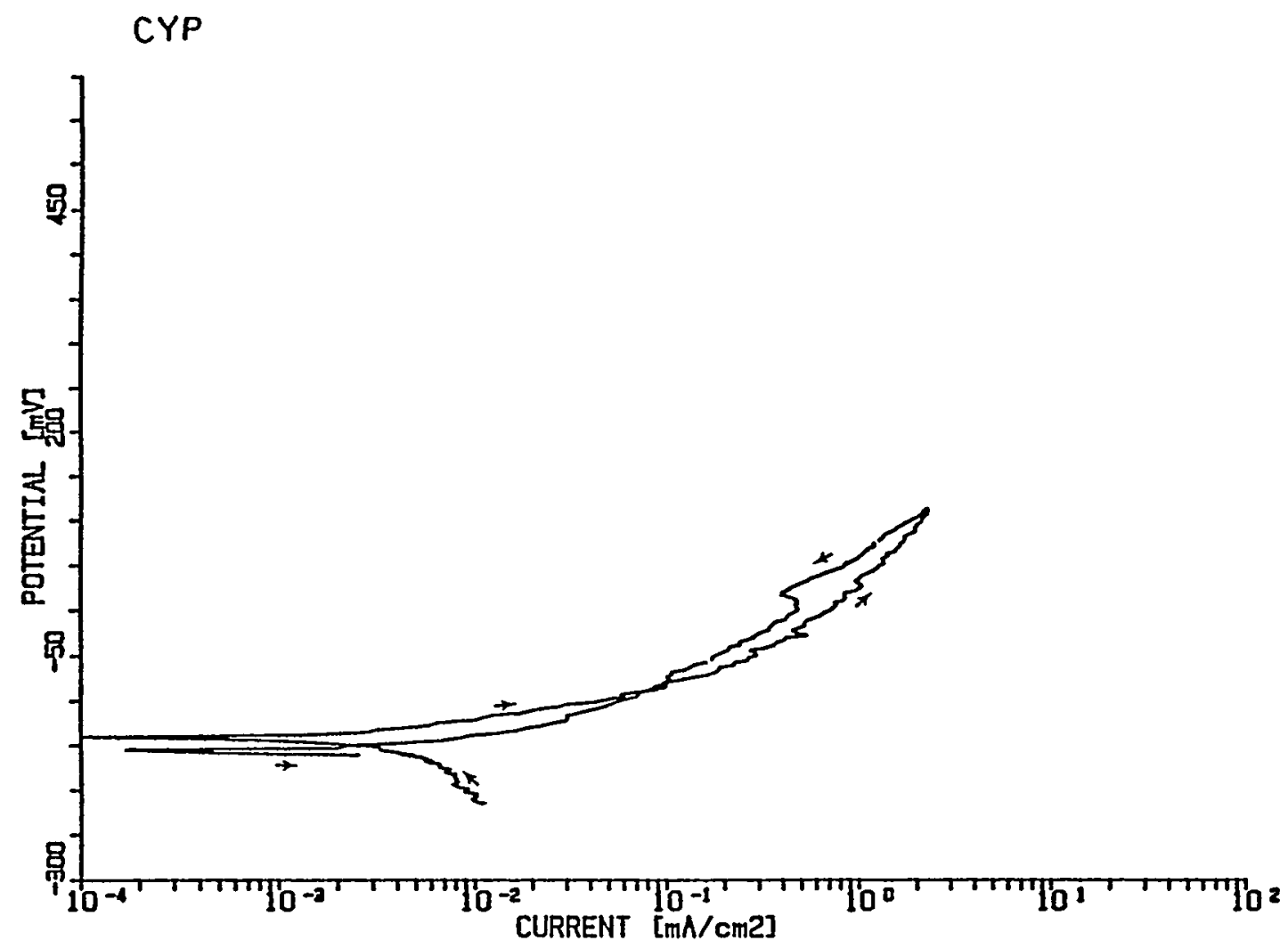

Figure 6.4 Polarization Curve For Alloy CDA 102 In Test Solution No. 7 At $90^{\circ} \mathrm{C}$.

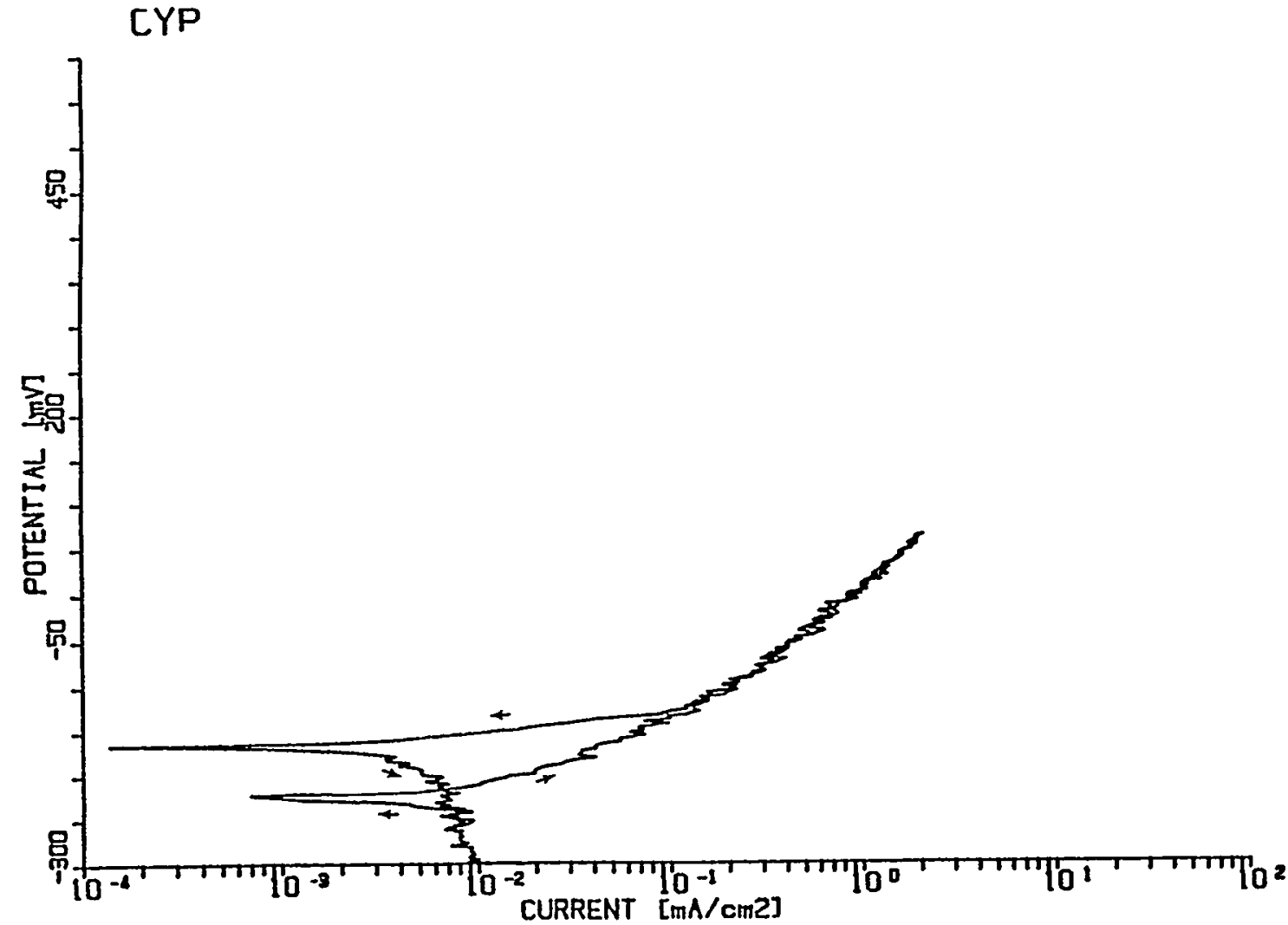

Figure 6.5 Polarization Curve For Alloy CDA 715 In Test Solution No. 7 At $90^{\circ} \mathrm{C}$. 


\section{DISCUSSION}

The overall objective of Task 3 was to evaluate the corrosion behavior of the candidate container materials in the Tuff Repository at times when the temperature is near the boiling point of water and periodic intrusion of vadose water occurs. The major difficulty in achieving this objective is that the environment in which the canister will be exposed is not well characterized. The J-13 well water is probably the most dilute environment that can be expected within the repository since boiling of the groundwater and its interaction with the host rock at elevated temperatures will tend to concentrate most species. The presence of the radiation field will generate new species, such as nitrites, carboxylic acids and hydrogen peroxide. Those species that are not volatile also may concentrate at the surface of the canister as a result of the combination of boiling and radiation.

Relatively little corrosion research has been performed in environments designed to simulate the concentration effects on the groundwater in the Tuff repository and these generally have been performed in uniformly concentrated groundwaters. This has been accomplished either by boiling actual J-13 well water (Pitman-1986 and Abraham-1986) or by preparing a concentrated simulated J-13 well water (Abraham-1986 and McCright-1985). In the latter case, all species were uniformly concentrated. These studies have provided useful information on container materials performance, and are discussed in greater detail in the Task 1 Topical Report (NUREG/CR-5435) and in the topical report to be issued for Task 7 of this program. In fact, in Task 7, long-term boil-down tests were performed to assess materials performance. However these tests probably do not accurately simulate actual repository conditions in that it is not likely that the species will uniformly concentrate because of (1) rock-water interactions, (2) corrosion product-water interactions, (3) retrograde solubility of some species and even (4) interaction of the groundwater with species from failed containers. Moreover, these studies have not considered, in general, the effects of the radiation field on the groundwater composition.

In Task 3 exposure studies, three simulated groundwaters were evaluated; a simulated $\mathrm{J}-13$ well water and two solutions selected from the experimental test matrix from Task 2 of the program (Solution Nos. 7 and 20). As described above, simulated J-13 well water is probably not a good simulation of the groundwater that will contact the waste containers because it is too dilute. Nevertheless, exposure testing in this environment provides good base-line information and a confirmation of the extensive research performed by DOE in J-13 well water. An alloy that performs poorly in the $\mathrm{J}-13$ well water probably can be rejected for further consideration as a container material. On the other hand, it cannot be concluded that an alloy that performs well in $\mathrm{J}-13$ well water is acceptable for construction of the waste containers.

The test matrix for Task 2 was designed to cover a 15 dimensional factor space that contains $\mathrm{J}$ 13 well water and considers a concentration of about a factor of 200 for most species. A concentration factor of 200 may be low for many of the species but is considered to be reasonable for a screening matrix such as that designed in Task 2. For example, chloride and nitrate concentrations of $1000 \mathrm{ppm}$ were used in the test matrix, whereas Abraham-1986 reported concentrations of $236 \mathrm{ppm}$ and $750 \mathrm{ppm}$ for chloride and nitrate respectively, following 6 month boil-down tests. Thus, much higher concentrations are possible for these species within the repository over hundreds of years. 
Solution Nos. 7 and 20 represent two points within this 15 dimensional factor space and were selected for the Task 3 work primarily because of the corrosion behavior exhibited by the candidate alloys in the environments. While it is not known whether these specific environments will be encountered, the maximum concentrations of the majority of the species within the solutions are thought to be reasonable, based on the above discussion. Further geochemical research is needed to better define the repository environment and how this environment might evolve over the life of the canister. If the factor space is believed reasonable, poor performance by a candidate container alloy in any of the of the solutions from the test matrix needs to be examined carefully in terms of the expected environment within the repository. Further discussion of the performance of the candidate alloys in these environments is given below.

\subsection{Fe-Cr-Ni Alloys}

The two Fe-Cr-Ni alloys were selected as candidate container alloys because of their resistance to general corrosion; they rarely fail in service by this mode. More commonly, these alloys fail by localized forms of corrosion such as pitting, crevice corrosion, or stress-corrosion cracking (SCC).

Both Alloy 825 and Alloy $304 \mathrm{~L}$ exhibited excellent resistance to general corrosion in $90^{\circ} \mathrm{C}$ simulated $\mathrm{J}-13$ well water with corrosion rates less than $0.2 \mu \mathrm{m} / \mathrm{yr}$ after approximately 2000 hours of exposure. This value extrapolates to a thickness loss of less than $0.2 \mathrm{~mm}$ in 1000 years. The actual thickness loss from general corrosion could also be considerably less, based on these data, since general corrosion rates of passive materials usually decrease with time of exposure. The results of the exposure tests on Alloy 304L also compare favorably with tests performed by McCright (1984) on stainless steels in $\mathrm{J}-13$ well water and in saturated steam at $100^{\circ} \mathrm{C}$. McCright's data, given in Table 7.1, shows the stainless steels to exhibited excellent resistance to general corrosion.

Polarization resistance (PR) measurements of both alloys indicated low corrosion rates, and again, these results compare favorably with tests performed by McCright (1984). McCright's data also indicate that the results of electrochemical studies performed on the stainless steels in $\mathrm{J}-13$ well water are generally consistent with the weight-loss data, although the electrochemistry predicts somewhat higher rates of attack. Figure 7.1 (McCright-1984) shows that corrosion rates based on two electrochemical measurement techniques (polarization resistance and Tafel extrapolation) decreased with time and were generally less than about $5 \mu \mathrm{m} / \mathrm{yr}$ after 500 hours of exposure. It is interesting to note that Alloy 825 specimens consistently exhibited higher rates of attack than did austenitic stainless steels in the electrochemical tests, although rates for all materials were moderate. Alloy 825 was not evaluated in the weight-loss studies by McCright (1984).

Glass (1984) and McCright (1984) also performed potentiodynamic-polarization studies on both Alloy $304 \mathrm{~L}$ and Alloy 825 in $\mathrm{J}-13$ water at temperatures ranging from $50^{\circ} \mathrm{C}$ to $100^{\circ} \mathrm{C}$ in an effort to predict their corrosion behavior. Their experiments were performed at a scan rate of $1 \mathrm{mV} / \mathrm{s}$ under naturally aerated conditions. Figure 7.2 illustrates the CPP curve for Alloy $304 \mathrm{~L}$ in actual $\mathrm{J}-13$ water. Figures $7.3 \mathrm{a}$ and $7.3 \mathrm{~b}$ give a summary of the pitting-related corrosion parameters $E_{\text {prot }}, E_{\text {pit }}$ and $E_{c o r}$ from their polarization studies which compare favorably with the data generated 
Table 7.1 Corrosion Test Results For Different Steel Coupons Exposed To $100^{\circ} \mathrm{C}$ TuffConditioned Water And Steam; 1000 Hour Exposure Of Triplicate Coupons (McCright-1984).

\begin{tabular}{|c|c|c|c|c|}
\hline \multirow[t]{2}{*}{ Material } & \multicolumn{2}{|c|}{$100^{\circ} \mathrm{C}$ Saturated Steam Atmospheric Pressure } & \multicolumn{2}{|c|}{$\begin{array}{l}100^{\circ} \mathrm{C} \mathrm{J}-13 \text { Water Conditioned With } \\
\text { Crushed Tuff Rock }\end{array}$} \\
\hline & $\begin{array}{c}\text { Corrosion Rates } \\
(\mu \mathrm{m} / \mathrm{yr})\end{array}$ & $\begin{array}{l}\text { Surface Condition } \\
\text { After Exposure }\end{array}$ & $\begin{array}{c}\text { Corrosion } \\
\text { Rates } \\
(\mu \mathrm{m} / \mathrm{yr})\end{array}$ & $\begin{array}{l}\text { Surface Condition } \\
\text { After Exposure }\end{array}$ \\
\hline $\begin{array}{l}\text { C1020 } \\
\text { Carbon Steel }\end{array}$ & $\begin{array}{l}43.43 ; 41.66 \\
60.20\end{array}$ & $\begin{array}{l}\text { Attack in all } 12 \text { crevices*; } \\
\text { localized attack elsewhere. }\end{array}$ & $\begin{array}{l}23.37 ; 29.97 \\
31.73\end{array}$ & $\begin{array}{l}\text { Attack in all } 12 \text { crevices; some light } \\
\text { localized attack elsewhere. }\end{array}$ \\
\hline $\begin{array}{l}\text { A36 } \\
\text { Carbon Steel }\end{array}$ & $\begin{array}{l}42.67 ; 46.48 \\
58.42\end{array}$ & $\begin{array}{l}\text { Attack in } 5 \text { crevices; much } \\
\text { localized attack elsewhere. }\end{array}$ & $\begin{array}{l}32.77 ; 39.35 \\
36.83\end{array}$ & $\begin{array}{l}\text { Attack in } 9 \text { crevices; some localized } \\
\text { attack elsewhere. }\end{array}$ \\
\hline $\begin{array}{l}\text { A366 } \\
\text { Carbon Steel }\end{array}$ & $\begin{array}{l}40.39 ; 52.07 \\
62.74\end{array}$ & $\begin{array}{l}\text { Light attack in } 7 \text { crevices; much } \\
\text { localized attack elsewhere. }\end{array}$ & $\begin{array}{l}25.65 ; 30.73 ; \\
27.94\end{array}$ & $\begin{array}{l}\text { Attack in all } 12 \text { crevices; very light } \\
\text { localized attack elsewhere. }\end{array}$ \\
\hline $\begin{array}{l}2.25 \mathrm{Cr}-1 \mathrm{Mo} \\
\text { Alloy Steel }\end{array}$ & $\begin{array}{l}7.87 ; 12.45 \\
15.49\end{array}$ & $\begin{array}{l}\text { Attack in } 7 \text { crevices; some } \\
\text { localized attack elsewhere. }\end{array}$ & $\begin{array}{l}29.21 ; 29.97 \\
31.75\end{array}$ & $\begin{array}{l}\text { Attack in all } 12 \text { crevices; consider- } \\
\text { able localized attack elsewhere. }\end{array}$ \\
\hline $\begin{array}{l}9 \mathrm{Cr}-1 \text { Mo } \\
\text { Alloy Steel }\end{array}$ & $\begin{array}{l}1.52 ; 1.78 ; \\
1.02\end{array}$ & $\begin{array}{l}\text { No evidence of crevice or other } \\
\text { localized attack. }\end{array}$ & $\begin{array}{l}4.06 ; 3.05 ; \\
3.30\end{array}$ & $\begin{array}{l}\text { No evidence of crevice or other } \\
\text { localized attack. }\end{array}$ \\
\hline $\begin{array}{l}409 \text { Stainless } \\
\text { Steel }\end{array}$ & $\begin{array}{l}\text { nilt; nil; } \\
\text { nil }\end{array}$ & $\begin{array}{l}\text { No evidence of crevice or other } \\
\text { localized attack. }\end{array}$ & $\begin{array}{l}\text { nil; nil; } \\
\text { nil }\end{array}$ & $\begin{array}{l}\text { No evidence of crevice or other } \\
\text { localized attack. }\end{array}$ \\
\hline $\begin{array}{l}416 \text { Stainless } \\
\text { Steel }\end{array}$ & $\begin{array}{l}\text { nil; } 0.25 ; \\
0.25\end{array}$ & $\begin{array}{l}\text { No evidence of crevice or other } \\
\text { localized attack. }\end{array}$ & $\begin{array}{l}0.25 ; 0.25 ; \\
0.25\end{array}$ & $\begin{array}{l}\text { No evidence of crevice or other } \\
\text { localized attack }\end{array}$ \\
\hline $\begin{array}{l}\text { 304L Stainless } \\
\text { Steel }\end{array}$ & $\begin{array}{l}\text { nil; } 0.25 ; \\
\text { nil }\end{array}$ & $\begin{array}{l}\text { No evidence of crevice or other } \\
\text { localized attack. }\end{array}$ & $\begin{array}{l}\text { nil;; } 0.25 ; \\
\text { nil }\end{array}$ & $\begin{array}{l}\text { No evidence of crevice or other } \\
\text { localized attack. }\end{array}$ \\
\hline $\begin{array}{l}\text { 316L Stainless } \\
\text { Steel }\end{array}$ & $\begin{array}{l}\text { nil; nil; } \\
\text { nil }\end{array}$ & $\begin{array}{l}\text { No evidence of crevice or other } \\
\text { localized attack. }\end{array}$ & $\begin{array}{l}0.51 ; 0.51 \\
0.51\end{array}$ & $\begin{array}{l}\text { No evidence of crevice or other } \\
\text { localized attack. }\end{array}$ \\
\hline $\begin{array}{l}\text { 317L Stainless } \\
\text { Steel }\end{array}$ & $\begin{array}{l}0.25 ; \text { nil; } \\
0.13\end{array}$ & $\begin{array}{l}\text { No evidence of crevice or other } \\
\text { localized attack. }\end{array}$ & $\begin{array}{l}0.25 ; 0.51 ; \\
0.76\end{array}$ & $\begin{array}{l}\text { No evidence of crevice or other } \\
\text { localized attack. }\end{array}$ \\
\hline
\end{tabular}

- nil is less than $0.13 \mu \mathrm{m} /$ year, which is based on our weight loss detection limit.

** The creviced washers contain 12 separated slots. 


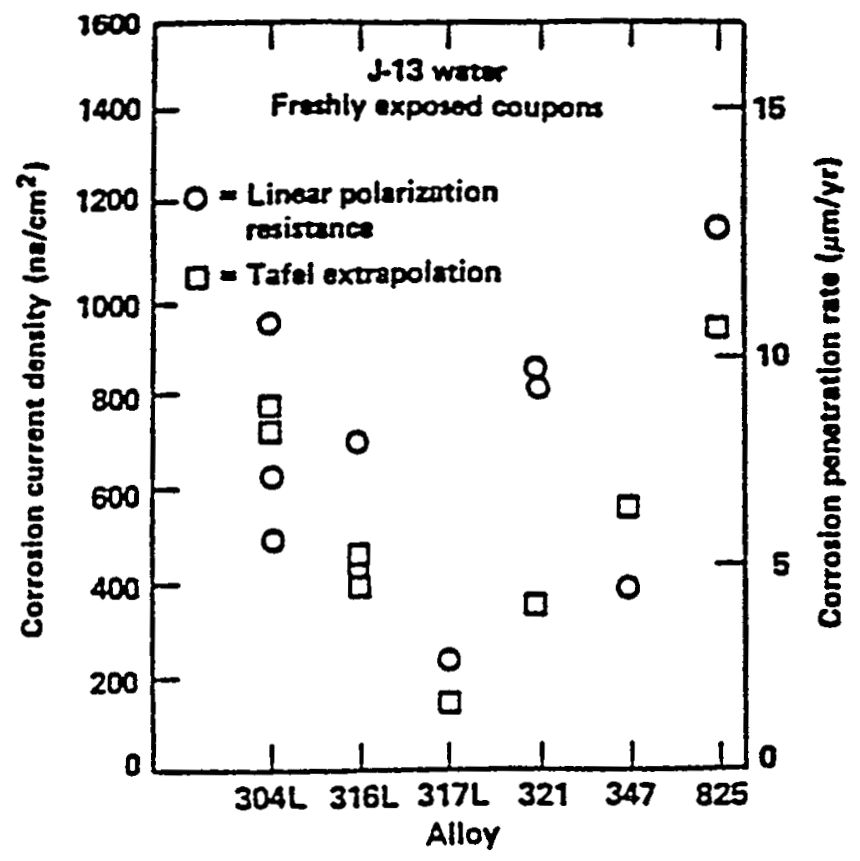

(a) Freshly Exposed Coupons.

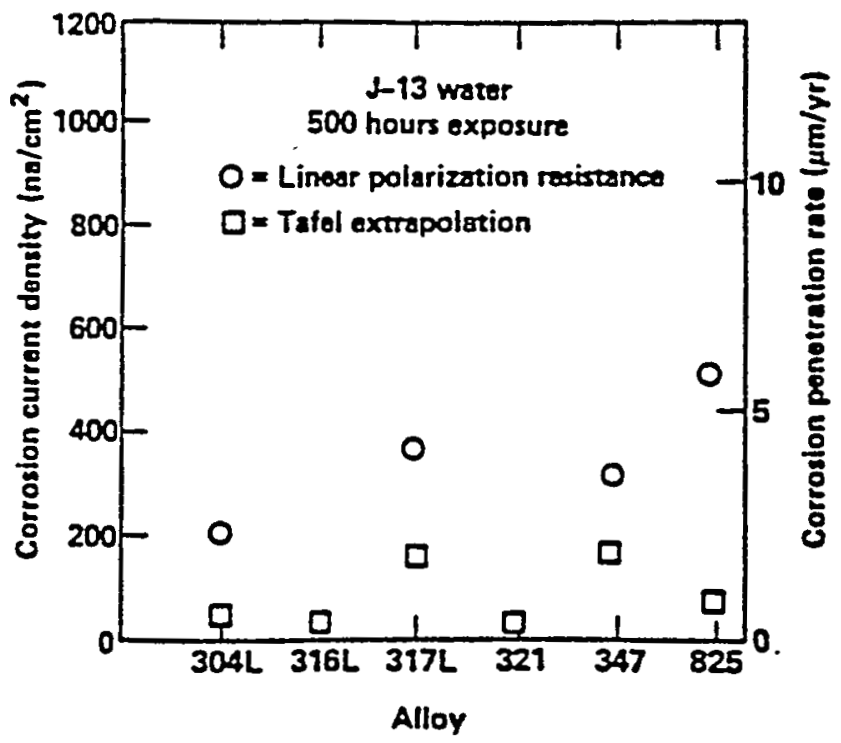

(b) Coupons Previously Exposed To This Environment For 500 Hours.

Figure 7.1 Electrochemical Determinations Of Corrosion Rates For Different Alloys In TuffConditioned J-13 Well Water At $100^{\circ} \mathrm{C}$ (McCright-1984). 


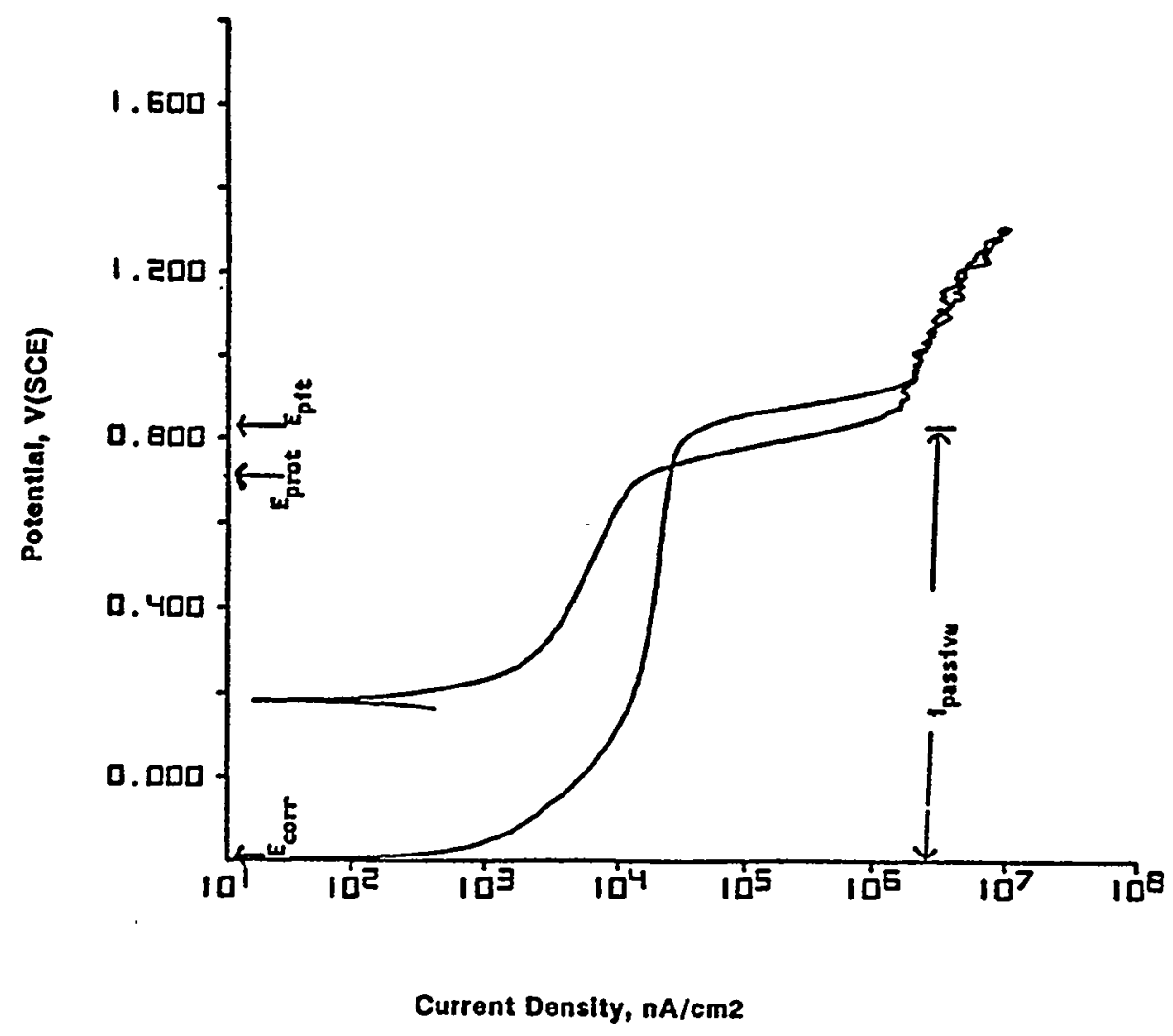

Figure 7.2 Potentiodynamic Anodic Polarization Curve For Alloy 304L In J-13 Well Water At $90^{\circ}$ C. Scan Rate Was $1 \mathrm{mV} / \mathrm{s}$. Scan Starts From $E_{\text {cor }}$ (Glass-1984). 


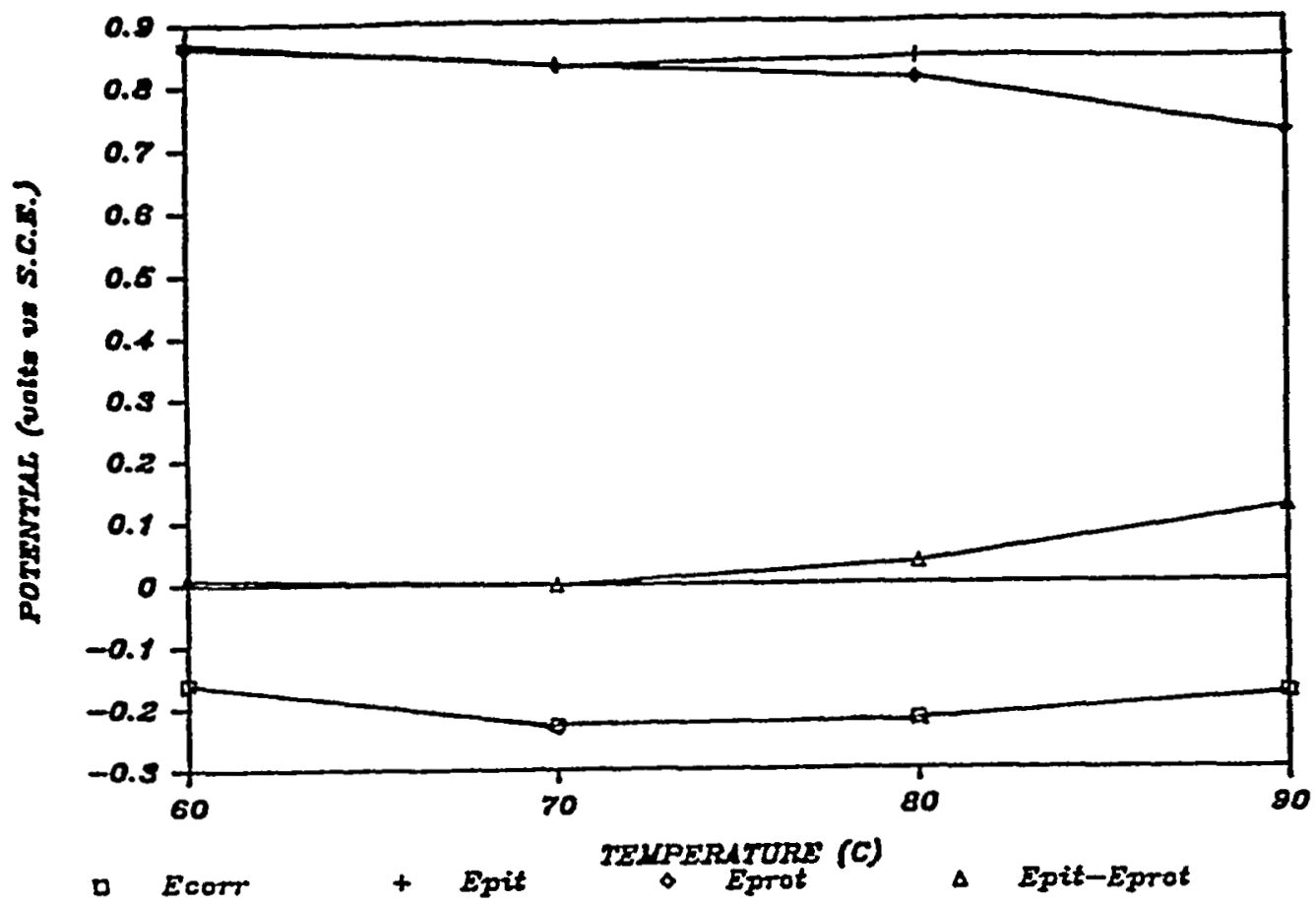

Figure 7.3a Electrochemical Parameters For Alloy 304L In Tuff-Conditioned J-13 Well Water As A Function Of Temperature (Glass-1984).

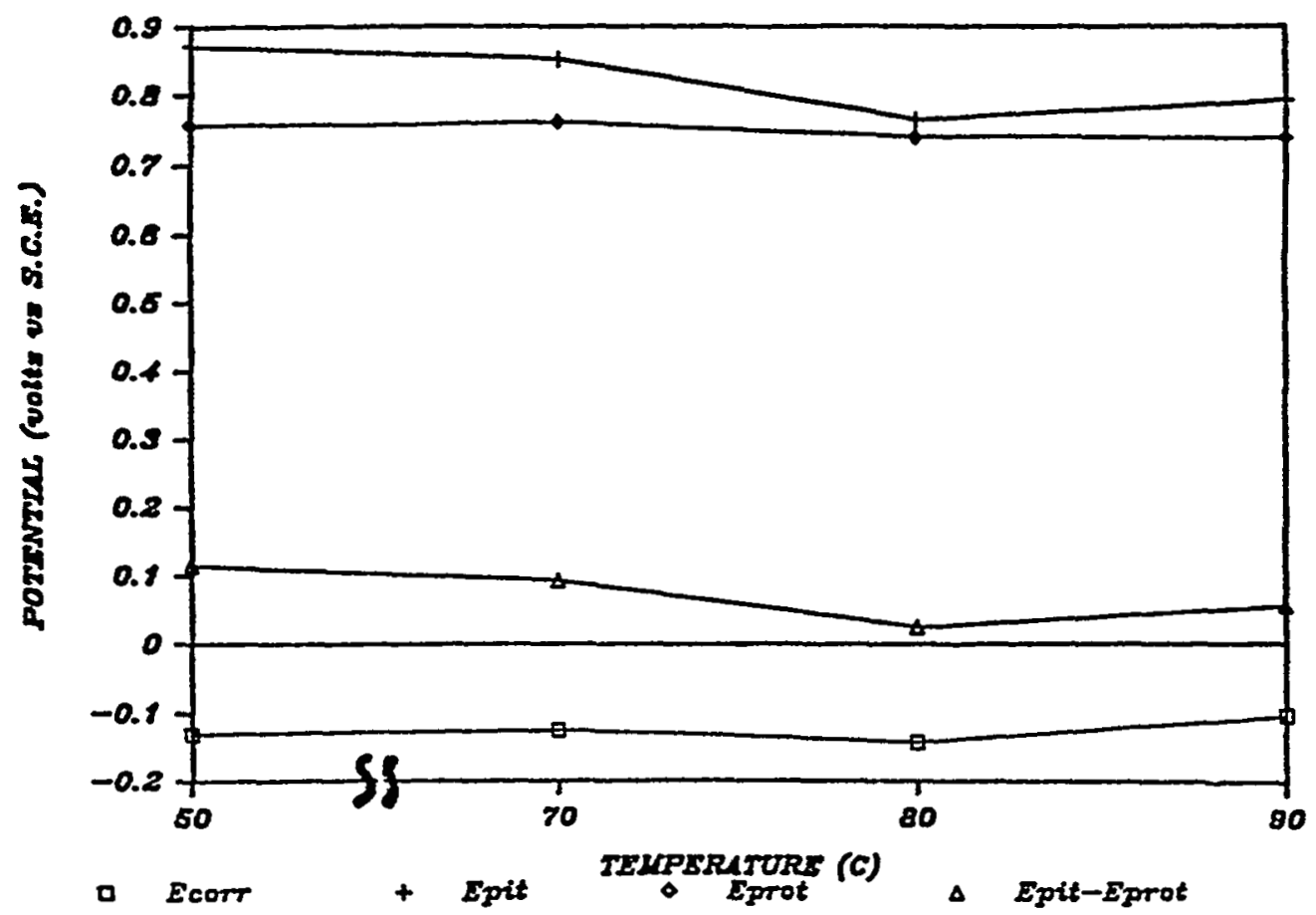

Figure 7.3b Electrochemical Parameters For Alloy 825 In Tuff-Conditioned J-13 Well Water As A Function Of Temperature (Glass-1984). 
from polarization studies at Cortest Columbus Technologies. These data show that $E_{\text {prot }}$ values are more noble than $\mathrm{E}_{\text {cor }}$ values by several hundred millivolts, indicating that pitting corrosion is relatively unlikely. No systematic effect of alloy composition on these parameters is evident from the data.

Exposure testing at Cortest Columbus Technologies revealed crevice corrosion in the form of light etching for both of the $\mathrm{Fe}-\mathrm{Cr}-\mathrm{Ni}$ alloys in simulated $\mathrm{J}-13$ well water. Some shallow pits were found on several of the Alloy 825 specimens in simulated $J-13$ well water where deposits had accumulated. However, the pit depth did not increase over the entire exposure period, suggesting, that either pit propagation ceased or decreased with time. Alloy 825 would be expected to be resistant to pitting in simulated $\mathrm{J}-13$ well water. Long-term testing is needed to further investigate this phenomenon.

Glass (1984) performed crevice corrosion tests of one year duration on the candidate alloys in $\mathrm{J}-13$ well water at temperatures ranging from $50^{\circ}$ to $100^{\circ} \mathrm{C}$. The crevices were formed by sandwiching flat metal specimens between ribbed Teflon washers. All of the alloys examined, including Alloy 825, showed some preferential attack in the crevices after one year of exposure, although the attack was minor having been described as staining. However, this staining is an indication that the protective passive films on the stainless steels are breaking down within the crevices. This behavior also demonstrates the difficulty of using the short-term electrochemical results to predict long-term behavior.

In the Cortest Columbus Technologies' studies, both Alloy 825 and Alloy $304 \mathrm{~L}$ exhibited excellent resistance to general corrosion in Solution No. 20, an active pitting solution designed to reflect chemical changes in the groundwater from boiling and radiolysis. General corrosion rates of less than $0.5 \mu \mathrm{m} / \mathrm{yr}$ were obtained by weight-loss measurements after approximately 2000 hours of exposure.

Data from the electrochemical measurements of Alloy 304L and Alloy 825 also indicated very low corrosion rates which correspond to high polarization resistance values that approached or were above our estimates for the detection limits for the measurement technique. Crevice corrosion in the form of light etching was also observed for both of the Fe-Cr-Ni alloys in Solution No. 20. The lack of pitting of the Fe-Cr-Ni alloys after 1029 hours exposure to an active pitting environment can be explained by the cyclic potentiodynamic polarization curves for these alloys. Corrosion potentials measured throughout the exposure remained below $E_{\text {prot }}$ for Alloy 825 and between $E_{p r o t}$ and $E_{p l t}$ for Alloy $304 \mathrm{~L}$. Values between $E_{p r o t}$ and $E_{p i t}$ suggest that pit initiation could possibly occur over time.

Hydrogen peroxide $\left(\mathrm{H}_{2} \mathrm{O}_{2}\right)$ was added to the exposure tests after approximately 2200 hours to further study possible radiolysis effects. Hydrogen peroxide is a chemical species found to occur as a result of irradiation of $\mathrm{J}-13$ groundwater. Following each $\mathrm{H}_{2} \mathrm{O}_{2}$ addition, a noble potential spike occurred, followed by a decline of the potential. For Alloy 825, the $\mathrm{H}_{2} \mathrm{O}_{2}$ addition moved the potential above $\mathrm{E}_{\text {prot }}$ but well below $\mathrm{E}_{\text {pit }}$. Alloy 825 appeared to catalyze the $\mathrm{H}_{2} \mathrm{O}_{2}$ degradation as evidenced by a sharp decline in the potential following each $\mathrm{H}_{2} \mathrm{O}_{2}$ addition. Corrosion rates determined from weight-loss measurements at the conclusion of the test remained low $(<0.5$ $\mu \mathrm{m} / \mathrm{yr}$ ) for Alloy 825 and there was no evidence of localized corrosion. 
Alloy 304L showed a much narrower range of potential change in the presence of $\mathrm{H}_{2} \mathrm{O}_{2}$ and the $\mathrm{H}_{2} \mathrm{O}_{2}$ appeared to degrade much slower. The corrosion potentials remained between $\mathrm{E}_{\text {prot }}$ and $\mathrm{E}_{\mathrm{plt}}$ during the entire 2855 hours of exposure. Although the $\mathrm{H}_{2} \mathrm{O}_{2}$ increased the potential slightly, it was insufficient to raise it above $\mathrm{E}_{\mathrm{plt}}$. However, specimen examination indicated very deep pits under and at the crevices at the conclusion of the test.

Probably the most serious potential problem for the stainless steel is SCC. Alloy 825 would be expected to be more resistant to SCC in the Tuff Repository environment as a result of its higher nickel content. No SCC was observed for either alloy after 2039 hours of exposure to $90^{\circ} \mathrm{C}$ simulated $\mathrm{J}-13$ well water. However, after 2855 hours of exposure to an active pitting environment (with $\mathrm{H}_{2} \mathrm{O}_{2}$ ), transgranular $\mathrm{SCC}$ was noted in the vapor-phase U-bend specimens of Alloy $304 \mathrm{~L}$. The cracking appeared to originate from deep pits in the stressed portions of the specimens. One possible explanation for pitting and cracking of only vapor-phase specimens may be related to the availability of the oxidant $\left(\mathrm{H}_{2} \mathrm{O}_{2}\right)$ to the specimen surface. These observations compare favorably to results by Pitman (1986), which indicated transgranular SCC for Alloy 304L under optimum metallurgical conditions in a simulated Tuff repository environment in the presence of a radiation field. No SCC was observed in any of the specimens of Alloy 825.

\subsection{Copper-Base Alloys}

In the present study, the copper-base alloys showed acceptable corrosion rates after 2024 hours of exposure to simulated $J-13$ well water at $90^{\circ} \mathrm{C}$. The corrosion rates, based on weight-loss measurements of Alloy CDA 102 specimens, were approximately an order of magnitude higher than those of Alloy CDA 715. The corrosion rates remained relatively constant for the first 1000 hours, then decreased thereafter. After 2024 hours, vapor, liquid, and alternate-immersion specimens of Alloy CDA 102 all exhibited comparable rates of corrosion which averaged 2.5 $\mu \mathrm{m} / \mathrm{yr}$. This corresponds to a thickness loss of 0.1 inches in 1000 years which is an acceptable corrosion rate.

The corrosion rates calculated from PR measurements using the Stern-Geary equation were higher than those obtained from weight loss in this study or by McCright (1985). For example, McCright reported a corrosion rate, based on weight loss, of 0.127 mils/year $(3.23 \mu \mathrm{m} / \mathrm{yr})$ for CDA 102 in $\mathrm{J}-13$ well water at $80^{\circ} \mathrm{C}$, see Table 7.2 , versus $5-25 \mu \mathrm{m} / \mathrm{yr}$ in the present electrochemical study. This discrepancy may be a consequence of the longer test time in the McCright study; general corrosion rates for passive materials usually decreased with time. It is probable that the discrepancy is also the result of spurious electrochemical reactions. Electrochemical techniques occasionally indicate higher rates of corrosion than weight loss where spurious electrochemical reactions are occurring. McCright (1985) reported rates as high as 2 mils/year $(51 \mu \mathrm{m} / \mathrm{yr})$ for CDA 102 in J-13 well water, based on potentiodynamic-polarization data (Figure 7.4).

In the present study, some incipient pitting was noted on specimens of Alloy CDA 102 in J-13 well water. The deepest pits, up to $34 \mu \mathrm{m}$, occurred in the vapor phase. Deeper pits, up to $53 \mu \mathrm{m}$, were noted on specimens of Alloy CDA 715 in the vapor near the vapor-liquid interface. The rate of pit propagation appeared to decrease with time for Alloy CDA 102, but increased with time for Alloy CDA 715. Assuming linear growth kinetics, a pit depth of $53 \mu \mathrm{m}$ corresponds to a depth of 0.23 meters in 1000 years. Of course, it is probably unreasonable to assume that linear growth 
Table 7.2 General Corrosion Penetration Rates Of Candidate Copper-Base Materials And Other Materials, For Comparison, In Tuff Repository Environmental Conditions (McCright-1985).

\begin{tabular}{|c|c|c|c|c|}
\hline \multirow[b]{2}{*}{ Alloy } & \multicolumn{4}{|c|}{ General Corrosion Rates (mils/y) } \\
\hline & $\begin{array}{c}80^{\circ} \mathrm{C} \mathrm{J}-13 \\
(3336 \mathrm{~h})\end{array}$ & $\begin{array}{c}100^{\circ} \mathrm{C} \mathrm{J}-13 \\
(6000 \mathrm{~h})\end{array}$ & $\begin{array}{c}\text { Wet Steam } \\
100^{\circ} \mathrm{C} \\
(6000 \mathrm{~h})\end{array}$ & $\begin{array}{c}\text { Dry Steam } \\
150^{\circ} \mathrm{C} \\
(3000 \mathrm{~h})\end{array}$ \\
\hline CDA 102 & 0.127 & 0.083 & 0.124 & 0.061 \\
\hline CDA 613 & 0.172 & 0.059 & 0.090 & 0.014 \\
\hline CDA 715 & 0.033 & 0.040 & 0.014 & 0.002 \\
\hline CDA 110 & 0.159 & ---- & $-\cdots$ & $\cdots-\cdots$ \\
\hline CDA 706 & 0.099 & $-\cdots$ & ---- & ---- \\
\hline Monel 400 & 0.016 & $-\cdots$ & ----- & -.--- \\
\hline
\end{tabular}




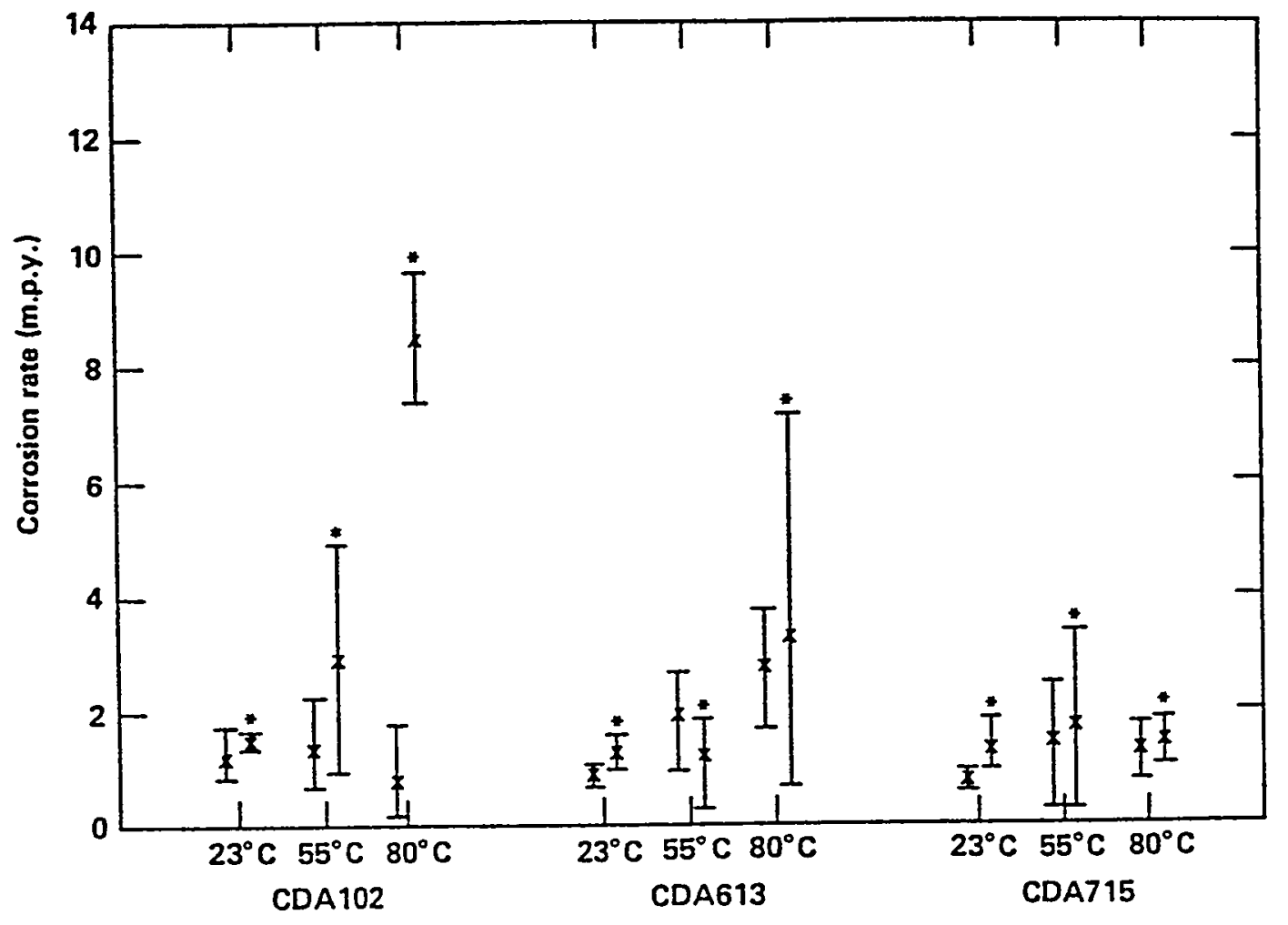

Figure 7.4 Corrosion Rates In J-13 And 100X Concentrated J-13 As A Function Of Temperature; ${ }^{*}=100 \times \mathrm{J}-13$ (McCright-1985). 
will occur and thus it is not clear whether these alloys have adequate resistance for use as a container material. Long-term exposure testing is needed to better characterize the long-term performance of the copper-base alloys.

McCright (1985) also evaluated the localized corrosion behavior of Alloy CDA 715 in J-13 well water at $80^{\circ} \mathrm{C}$ by the potentiodynamic-polarization technique at a scan rate of $1 \mathrm{mV} / \mathrm{s}$ under naturally aerated conditions. McCright's data, shown in Figure 7.5, indicated that localized corrosion was probable.

Results of research performed at Cortest Columbus Technologies (Beavers-1988) indicate that great care should be taken in interpreting the results of electrochemical studies performed on the copper-base alloys in Tuff environments. On Alloy CDA 102, two distinct types of corrosion processes have been associated with essentially identical polarization curves. In several simulated groundwaters, potentiodynamic polarization curves similar to that shown in Figure 7.5 have been obtained. In one environment, the hysteresis on the reverse scan was correlated with classical pitting. However, in several other environments, the hysteresis was associated with regions of passive film color change on the specimen, without apparent increases in rates of attack. This color change may be associated with a change in oxidation state of the film (e.g. from $\mathrm{Cu}^{+}$to $\mathrm{Cu}^{2+}$ ) and/or may represent the early stages of film breakdown. Further research is needed to investigate this phenomenon.

As was expected, the corrosion rates of the copper-base alloys were significantly higher in Solution No. 7 at $90^{\circ} \mathrm{C}$ then in simulated $\mathrm{J}-13$ well water. Solution No. 7 was selected from the experimental test matrix because it was found to be an active corrosion environment for these alloys, based on potentiodynamic-polarization tests. Corrosion rates, based on weight-loss measurements, were found to be several orders of magnitude higher for liquid-phase specimens in Solution No. 7 as compared to liquid-phase specimens in simulated J-13 well water. Corrosion rates of $44.2 \mu \mathrm{m} / \mathrm{yr}$ and $12.7 \mu \mathrm{m} / \mathrm{yr}$ were calculated from the weight-loss data for Alloy CDA 102 and Alloy CDA 715 respectively after 2014 hours of exposure to Solution No. 7. Vapor-phase specimens exhibited much lower corrosion rates than the liquid-phase specimens with rates of $1.6 \mu \mathrm{m} / \mathrm{yr}$ and $0.3 \mu \mathrm{m} / \mathrm{yr}$ for Alloy CDA 102 and Alloy CDA 715 respectively at the end of the exposure period.

Data from the electrochemical measurements of Alloy CDA 102 and Alloy CDA 715 also indicated higher corrosion rates in the liquid than in the vapor phase. Again, comparison of the electrochemical data with actual weight-loss data shows that the electrochemistry consistently overestimated the corrosion rates for both of the copper-base alloys. Again, this behavior is typical for PR measurements and is probably a consequence of the presence of spurious (noncorrosion) electrochemical reactions in the test electrolyte.

Optical examination of the specimens revealed severe crevice corrosion and pitting in both alloys in the liquid phase and light to moderate etching and a few shallow pits in the vapor phase of Solution No. 7. Although the corrosion rates, as calculated from the PR measurements, decreased with time, localized pitting was extensive. Pits as deep as $98 \mu \mathrm{m}$ and $147 \mu \mathrm{m}$ for Alloy CDA 715 and Alloy CDA 102, respectively, were measured after approximately 2013 hours of exposure to the liquid phase. The precision-machined rod used to evaluate corrosion at the 


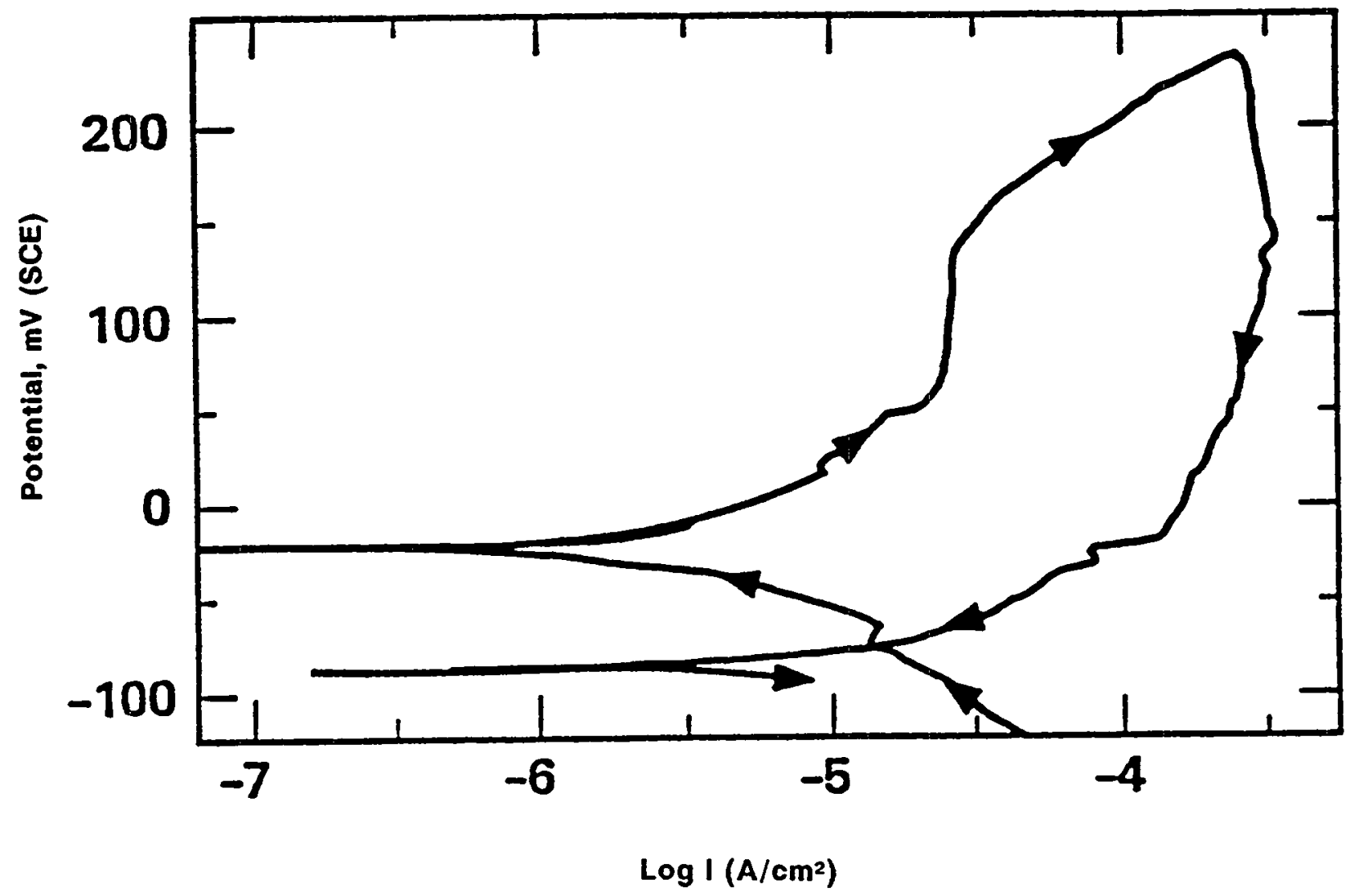

Figure 7.5 Polarization Behavior Of Alloy CDA 715 In J-13 Well Water At $80^{\circ} \mathrm{C}$ At A Scan Rate Of $1 \mathrm{mV} / \mathrm{sec}$ (McCright-1985). 
vapor-liquid interface showed severe attack. Pitting and etching were also noted on U-bend specimens in both simulated $\mathrm{J}-13$ well water and Solution No. 7. However, no SCC was found to occur.

The cyclic-potentiodynamic-polarization curves for these alloys in Solution No. 7 are not fully consistent with the results of these exposure tests; the polarization curves were shown in Figures 6.4 and 6.5. These curves are characteristic of active behavior with no hysteresis or other indication of localized forms of corrosion. The localized corrosion observed in the exposure tests may be a consequence of the occurrence of differential aeration cells on the specimens as a result of the presence of the crevice washers and deposits on the specimens. Alternatively, the discrepancy may be attributed to the fact that the polarization curves do not represent steady state behavior for the copper-base alloy-environment systems.

Data in the literature on SCC of copper-base alloys in J-13 well water (in the absence of a radiation field) were not found. Results of exposures of CDA 102, CDA 613 and CDA 715 in irradiated J-13 well water and the vapors above those waters are described by Yunker (1986a) and Acton (1986). Yunker (1986a) exposed teardrop shaped stress-corrosion specimens of CDA 102, CDA 613 and CDA 715 to three simulated Tuff repository environments in the presence of a radiation field. The teardrop specimens were prepared by the single stressing method according to ASTM G30-79, and the specimen ends were fusion welded. The three environments were aerated $\mathrm{J}-13$ well water at $95^{\circ} \mathrm{C}$, water saturated air at $95^{\circ} \mathrm{C}$ and air-water vapor at $150^{\circ} \mathrm{C}$. A gamma field of $1 \times 10^{5} \mathrm{R} /$ hour was used in the study. Following exposure, the specimens were examined optically and by means of dye penetrants.

Acton (1986) reported on the results of 6-month exposures. No evidence of cracking was found visually or by means of dye penetrant for any of the alloys evaluated. Metallographic examinations of the specimens had not been completed at the time of reporting. In subsequent work, Yunker (1986b) reported on the results of 14 month exposures under the above test conditions. Again, there was no evidence of SCC, based on optical and dye-penetrant examination of the tear-dropped specimens following exposure.

In spite of the apparent good SCC performance in the above tests, cracking remains as a potentially serious problem for the copper-base alloys. As shown in Table 7.3, historically, SCC of copper-base alloys has been observed in numerous environments including sulfates, nitrates, nitrites, ammonia, humid air and steam. While $\mathrm{Cu}-\mathrm{Zn}$ alloys predominate in the table, this may reflect, in part, the fact that the brasses are used extensively and more stress-corrosion research has been performed on these alloys than on other alloys. It is generally established that pure copper and copper-nickel alloys are more resistant to SCC than are most other copper-base alloys. However, as shown in Table 7.3, these alloys are susceptible to SCC in several of the reported cracking environments. Further research is needed to investigate some of these environmental variables that will result from radiolysis of the $\mathrm{J}-13$ well water. 
Table 7.3 Summary Of Environments Known To Promote Stress-Corrosion Cracking Of Copper-Base Alloys. (Beavers 1990a)

\begin{tabular}{|l|l|l||}
\hline \multicolumn{1}{|c|}{ Environment } & \multicolumn{1}{|c||}{ Alloy } & \multicolumn{1}{c||}{ Reference } \\
\hline Ammonia & Pure Coppper, Cu-Ni & Thompson-1944 \\
Nitrites & Pure Copper & Benjamin-1983 \\
Steam & Al Bronze & Klement-1959 \\
Steam & Cu-Ni & Sato-1974a \\
Ammonia & Al Brass & Sato-1974a \\
Room Temperature Humid & Cu-Zn Alloys & Sato-1974b \\
Air & Cu-Zn Alloys & Kawashima-1979 \\
SO ${ }_{4}^{2-}$ & Cu-Zn & Kraf-1969 \\
Nitrates & Cu-Zn & Kawashima-1977 \\
ClO $_{3}^{-}$ & & \\
\hline \hline
\end{tabular}




\section{CONCLUSIONS}

Based on the preceding data and discussions, the following conclusions can be drawn:

- From the standpoint of general corrosion, the Fe-Cr-Ni alloys all performed well and exhibited low corrosion rates in simulated $\mathrm{J}-13$ well water.

- In simulated J-13 well water, no pitting, was observed on Alloy 304L specimens.

- Alloy 825 exhibited incipient pitting under deposits in simulated J-13 well water. These pits did not appear to propagate with time.

- Slight etching was observed for both Fe-Cr-Ni alloys in simulated J-13 well water beneath crevices.

- The Fe-Cr-Ni alloys all performed well and exhibited low corrosion rates in a pitting solution (Solution No. 20) in the absence of hydrogen peroxide $\left(\mathrm{H}_{2} \mathrm{O}_{2}\right)$.

- $\quad$ Alloy 825 performed well and continued to exhibit low corrosion rates after $\mathrm{H}_{2} \mathrm{O}_{2}$ was added to the pitting solution to simulate the effects of radiolysis. Alloy $304 \mathrm{~L}$, however, exhibited pitting and $\mathrm{SCC}$ as a result of the $\mathrm{H}_{2} \mathrm{O}_{2}$ additions.

- The SCC of vapor-phase specimens of Alloy $304 \mathrm{~L}$ in Solution No. 20 containing $\mathrm{H}_{2} \mathrm{O}_{2}$ may possibly be a reproduction of vapor-phase cracking reported by Pitman (1986).

- The copper-base alloys showed acceptable general corrosion rates in simulated J-13 well water. The corrosion rates were found to decrease over time.

- The copper-base alloys exhibited pitting in simulated $J-13$ well water. The rate of pit propagation appeared to decrease with time for Alloy CDA 102, but increased with time for Alloy CDA 715. Long-term exposure testing is needed to better characterize the longterm performance of the copper-base alloys.

- Corrosion rates of the copper-base alloys were moderate and decreased with time in Solution No. 7.

- Severe pitting and crevice corrosion was observed on copper-base alloys exposed to Solution No.7, an active-corrosion solution based on CPP curves.

- In Solution No. 7, rates of pitting appeared to decrease with time for Alloy CDA 102, but appeared to be relatively constant for Alloy CDA 715.

- $\quad$ Although no SCC was exhibited on U-bend specimens of either of the copper-base alloys in either simulated $\mathrm{J}-13$ well water or Solution No. 7 , cracking remains as a potentially serious problem for the copper-base alloys. Further research is needed to investigate the susceptibility to SCC in environments resulting from radiolysis of the $J-13$ well water.

$$
91 / 92
$$




\section{REFERENCES}

Acton-1986 - Acton, C. F. and McCright, R. D., "Feasibility Assessment Of Copper-Base Waste Package Container Materials In A Tuff Repository", Lawrence Livermore National Laboratory, UCID-20847, September, 1986.

Abraham-1986 - Abraham, T., Jain, H., and Soo, P., "Stress-corrosion Cracking Tests On HighLevel-Waste Container Materials In Simulated Tuff Repository Environments", Brookhaven National Laboratory, NUREG/CR-4619, BNL-NUREG-51996, June, 1986.

Beavers-1987 - Beavers, J. A. and Thompson, N. G., et al., "Long-Term Performance of Container Materials for High-Level Waste", NUREG/CR-4955, BMI-2155, September, 1987.

Beavers-1988 - Beavers, J. A. and Thompson, N. G., "Container Corrosion In High Level Nuclear Waste Repositories", Cortest Columbus, Inc., Second Semi-Annual Report, Year 1, March, 1988 August 1988, under Contract No. NRC-04-87-069, NRC FIN D1692 for U.S. Nuclear Regulatory Commission.

Beavers-1989 - Beavers, J. A. and Thompson, N. G., "Container Corrosion In High Level Nuclear Waste Repositories", Cortest Columbus, Inc., First Semi-Annual Report, Year 2, September 1988 - February, 1989, under Contract No. NRC-04-87-069, NRC FIN D1692 for U.S. Nuclear Regulatory Commission.

Beavers-1989a - Beavers, J. A. and Thompson, N. G., "Container Corrosion In High Level Nuclear Waste Repositories", Cortest Columbus, Inc., Second Semi-Annual Report, Year 2, March, 1989 - August, 1989, under Contract No. NRC-04-87-069, NRC FIN D1692 for U.S. Nuclear Regulatory Commission.

Beavers-1990 - Beavers, J. A. and Durr, C. L., "Container Corrosion In High Level Nuclear Waste Repositories", Cortest Columbus, Inc., First Semi-Annual Report, Year 3, September, 1989 February 1990, under Contract No. NRC-04-87-069, NRC FIN D1692 For U.S. Nuclear Regulatory Commission.

Beavers-1990a - Beavers, J. A. and Thompson, N. G., "Environmental Effects On Corrosion in The Tuff Repository", Cortest Columbus, Inc., Columbus, Ohio, NUREG/CR-5435.

Benjamin-1983 - Benjamin, L. A., Hardie, D. and Parkins, R. N., University of Newcastle-UponTyne, England, Report No. 83-06/SKBF/KBS.

Glass-1984 - Glass, R. S., Overturf, G. E., Garrison, R. E., McCright, R. D., "Electrochemical Determination Of The Corrosion Behavior Of Candidate Alloys Proposed For Containment Of High Level Nuclear Waste In Tuff", Lawrence Livermore National Laboratory, Livermore, CA, UCID20174, June, 1984. 
Glass-1985 - Glass, R. S., Overturf, G. E., Van Konynenburg, R. A., and McCright, R. D., "Gamma Radiation Effects On Corrosion: I Electrochemical Mechanisms For The Aqueous Corrosion Processes Of Austenitic Stainless Steels", Lawrence Livermore National Laboratory, Livermore, CA, UCRL-92311, February, 1985.

Glass-1986 - Glass, R. S., Van Konynenburg, R. A., and Overturf, G. E., "Corrosion Processes Of Austenitic Stainless Steels And Copper-Based Materials In Gamma-Irradiated Aqueous Environments", Corrosion-86, Paper No. 258 and Lawrence Livermore National Laboratory, Livermore, CA, UCRL-92941, September, 1985.

Glassley-1986 - Glassley, W. E., "Reference Waste Package Environment Report", Lawrence Livermore National Laboratory, Livermore, CA, UCRL-53726, October 1, 1986.

Graf-1969 - Graf, L., "Stress-corrosion Cracking In Homogeneous, Non-Supersaturated Alloys Containing Noble Or No Noble Metals", Fundamental Aspects Of Stress-corrosion Cracking, Eds. Staehle, R.W., et. al., NACE 1969, p. 197.

Johnstone-1981 - Johnstone, J. K. and Wolfsberg, K., editors, "Evaluation Of Tuff As A Medium For A Nuclear Waste Repository: Interim Status Report On The Properties Of Tuff", Sandia National Laboratories, SAND80-1464, July, 1981.

Kawashima-1977 - Kawashima, A., Agrawal, A. K. and Staehle, R. W., "Stress-corrosion Cracking Of Admiralty Brass In Non-Ammoniacal Sulfate Solutions", J. Electrochem. Soc., Vol. 124, p. 1822.

Kawashima-1979 - Kawashima, A., Agrawal, A. K. and Staehle, R. W., "Stress-corrosion Cracking - The Slow Strain Rate Technique", Ugiansky, G. M., Payer, J. H., ASTM STP 665, American Society For Testing and Materials.

Klement-1959 - Klement, J. F., Maersch, R. E. and Tully, P. A., Metal Progress, 75, (2), p. 83.

Knauss-1985a - Knauss, K. G., Beiriger, W. J. and Peifer, D. W., "Hydrothermal Interaction Of Crushed Topopah Spring Tuff and J-13 Water At 90,150 , and $250^{\circ} \mathrm{C}$ Using Dickson-Type, GoldBag Rocking Autoclaves", Lawrence Livermore National Laboratory, Livermore, CA, UCRL-53630, DE86-014752, May, 1985.

Knauss-1985b - Knauss, K. G., Beiriger, W. B., Peifer, D. W. and Piwinskii, A., "Reaction of Solid Wafers Of Topopah Spring Tuff With J-13 Water At 90,150 , and $250^{\circ} \mathrm{C}$ In Dickson-Type, GoldBag Rocking Autoclaves: 1. Short-Term Experiments", Lawrence Livermore National Laboratory, Livermore, CA, UCRL-53645.

Koch-1988 - Koch, G. H., Spangler, J. M., and Thompson, N. G., "Corrosion Studies In Complex Environments", The Use Of Synthetic Environments For Corrosion Testing, ASTM STP970, P. E. Francis And T. S. Lee, Eds., American Society For Testing And Materials, philadelphia, PA, 1988, pp. 3-17. 
McCright-1984 - McCright, R. D., Weiss, H., Juhas, M. C., and Logan, R. W., "Selection Of Candidate Canister Materials For High-Level Nuclear Waste Containment In A Tuff Repository", Lawrence Livermore National Laboratory, Livermore, CA, UCRL 89988 and Corrosion '84, Paper No. 198, April, 1984.

McCright-1985 - McCright, R. D., "FY 1985 Status Report On Feasibility Assessment Of CopperBase Waste Package Container Materials In A Tuff Repository", Lawrence Livermore National Laboratory, Livermore, CA, UCID-20509, September, 1985.

Montazer-1984 - Montazer, P. and Wilson, W. E., "Conceptual Hydrologic Model of Flow In The Unsaturated Zone, Yucca Mountain, Nevada", U. S. Geological Survey - Water Resources Investigation Report, USGS-WRI-84-4345, 1984.

Oversby-1983 - Oversby, V. M., Knauss, K. G., "Reaction Of Bullfrog Tuff With J-13 Well Water At $90^{\circ} \mathrm{C}$ and $150^{\circ} \mathrm{C}$ ", Lawrence Livermore National Laboratory, Livermore, CA, UCRL-53442, DE84-000659, September, 1983.

Pitman-1986 - Pitman, S. G., Westerman, R. E., Haberman, J. H., "Corrosion And Slow Strain Rate Testing Of Type 304L Stainless Steel In Tuff Groundwater Environments", Pacific Northwest Laboratory, Richland, WA, PNL-SA-14396, DE87-006404, October, 1986.

Sato-1974a - Sato, S. and Nagata, K., "Stress-corrosion Cracking Of Copper Alloys In Pure Steam And Water At High Temperatures", Boshoku Gijustu, Vol. 23, pp. 125-133.

Sato-1974b - Sato, S. and Nagata, K., "Case Studies On The Failures Of Copper And Copper Alloys By Stress-corrosion Cracking", Sumitomo Light Metal Technical Reports, Vol. 15:3, pp. 174-185, July, 1974.

Schuraytz-1985 - Schuraytz, B., "Geochemical Gradients In The Topopah Spring Member Of The Paintbrush Tuff: Evidence For Eruption Across A Magmatic Interface", Lawrence Livermore National Laboratory, Livermore, CA, UCRL-53698.

Thompson-1944 - Thompson, D. H. and Tracy, A. W., Trans. AIME, 185, p. 100.

Van Konynenburg-1986 - Van Konynenburg, R. A., "Radiation Chemical Effects In Experiments To Study The Reaction Of Glass in A Gamma-Irradiated Air, Groundwater, And Tuff Environment", Lawrence Livermore National Laboratory, Livermore, CA, UCRL-53719.

Yunker-1986a - Yunker, W. H., "Corrosion Of Copper-Based Materials In Gamma Radiation", Westinghouse Hanford Company, HEDL-7612, DE87-005494, June, 1986.

Yunker-1986b - Yunker, W. H., Westinghouse Hanford Company, and Glass, R. S., Lawrence Livermore National Laboratory, "Long-Term Corrosion Behavior Of Copper-Base Materials In A Gamma-Irradiated Environment", UCRL-94500, DE87-007098, December, 1986. 


\title{
APPENDIX A
}

\author{
The Potentiodynamic Polarization Technique
}

For Corrosion Evaluation

The cyclic-potentiodynamic-polarization (CPP) technique was used in this project to provide an understanding of how the specific variables, environmental composition, temperature, and alloy composition affect the general and pitting corrosion behavior of the alloys in simulated repository environments.

In the CPP procedure, the polarity and magnitude of the current flow between a specimen of the material of interest and an inert counter electrode are measured as a function of electrochemical potential. For the anodic portions of the curve, the current measured is equal to the corrosion rate of the specimen if two conditions are met: (1) The electrochemical potential is far enough away from the open-circuit potential that the rate of the cathodic reaction is negligible; and (2) The rates of spurious oxidation reactions are negligible.

Schematics of anodic polarization curves showing several types of behavior are given in Figure A.1. For the active-corrosion case, the anodic curve is linear on an E-log i plot, and the forward and reverse scans are coincident. The presence of a peak in the anodic portion of the curve, followed by decreasing current, is generally indicative of the onset of passivation. The occurrence of hysteresis between the forward and reverse scans is indicative of pitting. Where the hysteresis loop is very large, the protection potential may be very close to the open-circuit potential, indicating a high probability of pitting in that particular environment.

The polarization behavior of the alloys was determined using conventional polarization techniques. The specific polarization equipment used for these experiments included a Princeton Applied Research Model 273 potentiostat coupled to a computer data-acquisition system or a Santron Electrochemical Measuring System. A two-compartment electrochemical cell was employed that utilized a saturated-calomel reference electrode (SCE) and a platinum counter electrode (Figure A.2). Originally, it was planned to use a three-compartment cell (working, counter, and reference compartments), but the relatively high resistance of several of the solutions prevented its use, and the two-compartment cell was used for all tests. The working electrode specimens were cylindrical rods that were drilled, tapped at one end, and sealed off using PTFE gaskets. The specimens were typically $1.3 \mathrm{~cm}$ in length with the diameter depending on the metal being tested. The electrodes were polished with successively finer grades of silicon carbide paper, finishing with a 600-grit gradè.

A typical experlment consisted of the following procedure. Prior to testing, the working electrode was immersed in the test solution overnight while the solution was sparged with the desired gas mixture. The CPP test was then performed approximately 16 hours after immersion of the working electrödè in the cell.

The workilng electrôde lead was cónnected to the test specimien while the auxiliary (counter) electrode lead wäs connected to an inert electrode (platinum wire) placed in the test cell. The reference electrode lead was connected to the reference electrode which communicates with the test cell electrolyte through a small diameter tube filled with électrólyte, referred to as à Luggin 


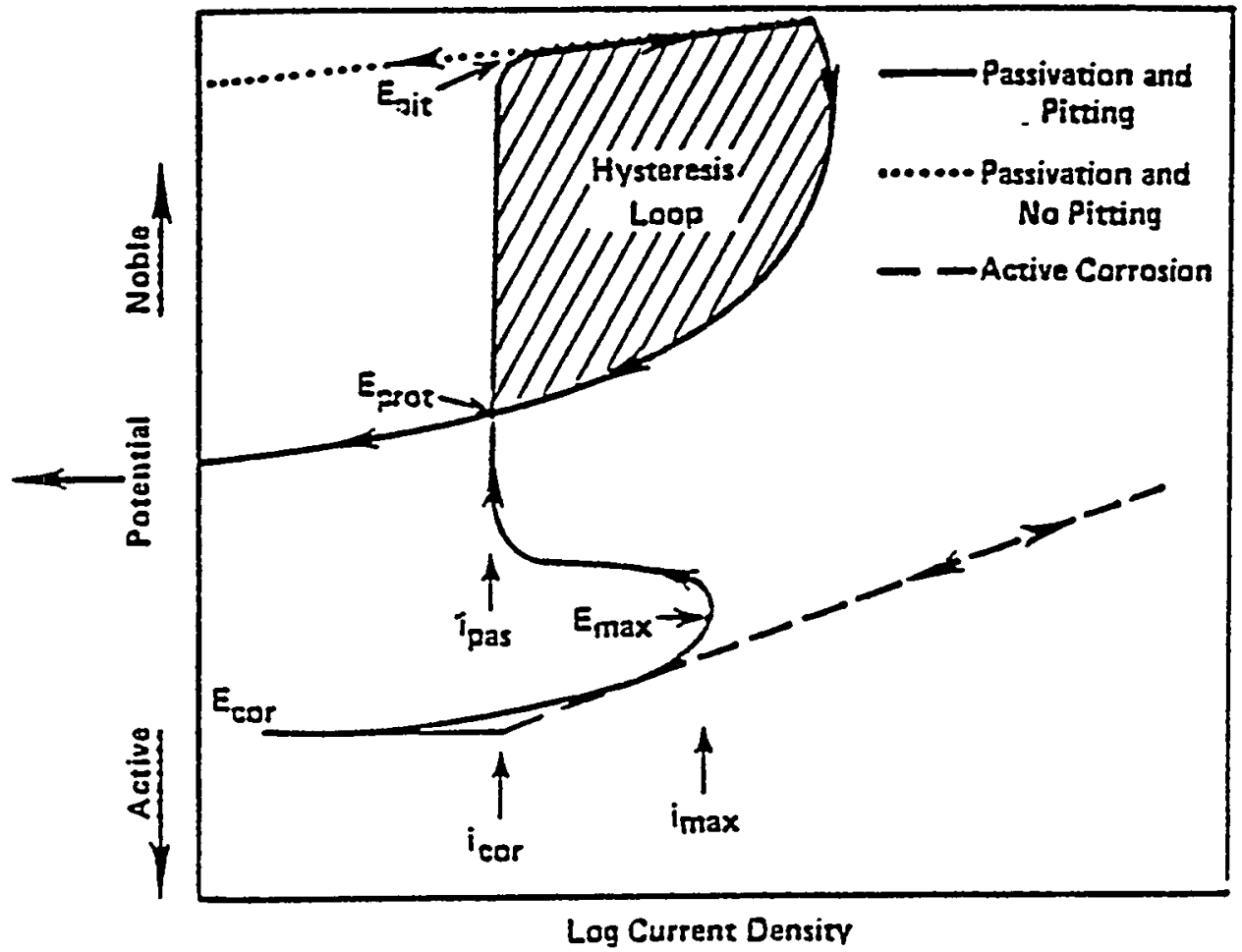

Figure A.1 Schematic Of Typical Anodic Potentiodynamic Polarization Curves.

$E_{c o r}=$ corrosion potential; $E_{p l t}=$ potential at which pits initiate on fonward scan; $E_{\text {prot }}$ $=$ potential at which pits repassivate on reverse scan; $i_{c o r}=$ current density at the free-corrosion potential; $i_{\max }=$ current density at active peak; $i_{p a s}=$ current density in passive range. 


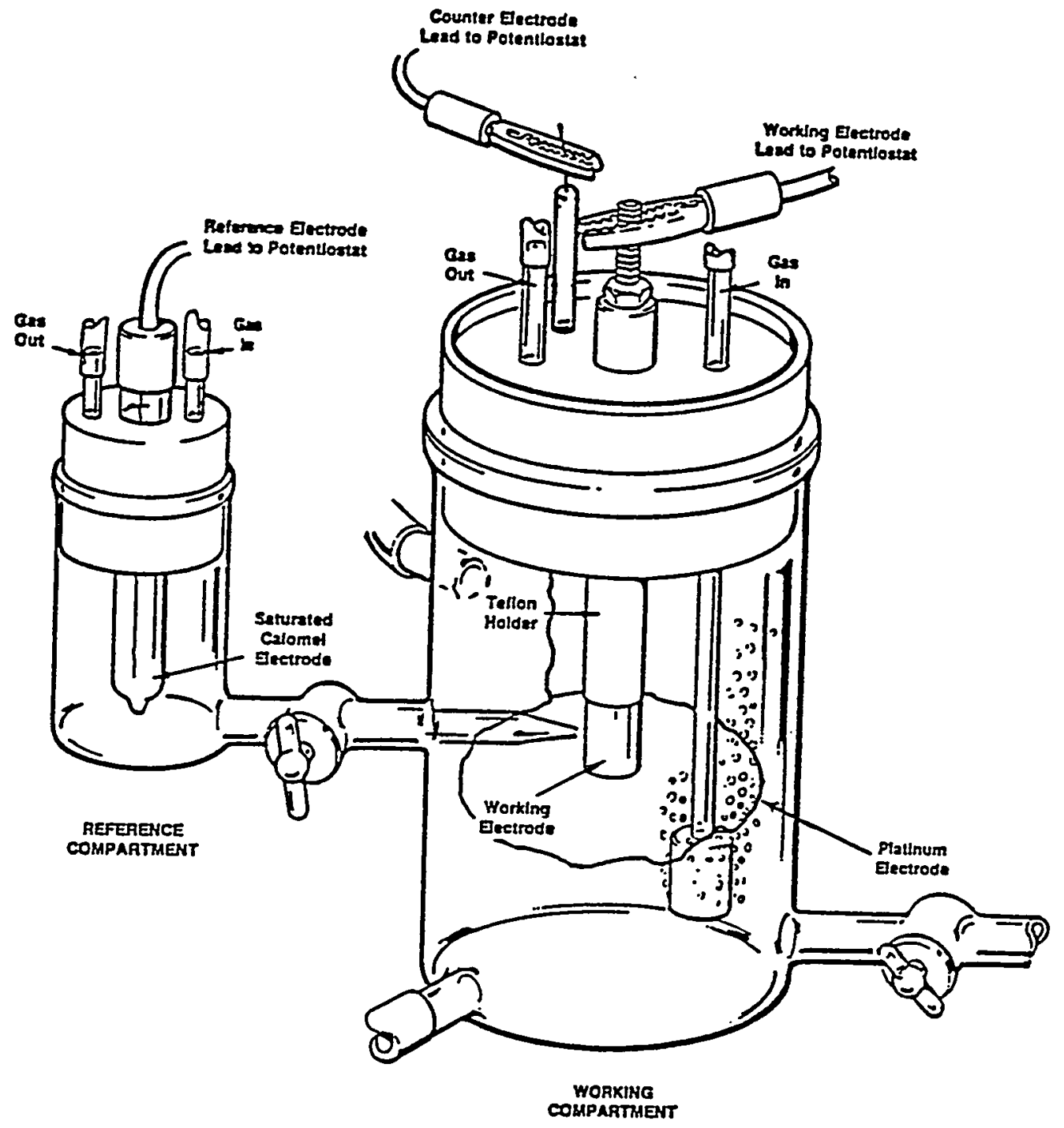

Figure A.2 Electrochemical Cell Used For Ambient Pressure Potentiodynamic Polarization Experiments. 
probe or salt bridge. The tip of the probe is placed near the test specimen to minimize measurement errors due to ohmic potential drops.

Partial cathodic and full anodic polarization curves were obtained by scanning at a rate of $0.6 \mathrm{~V} / \mathrm{h}$ and beginning the scan approximately $100 \mathrm{mV}$ more negative than the free-corrosion potential. The current for the anodic curve was scanned until a current density of approximately $2 \times 10^{-3}$ $\mathrm{A} / \mathrm{cm}^{2}$ was attained; the potential scan was then reversed until repassivation occurred and the current changes polarity, becoming cathodic.

After completion of the polarization scans, the following polarization parameters were obtained from the polarization curves of potential $(E)$ versus logarithm of current density (log I) when applicable: $i_{c o r}, E_{c o r}, i_{p a s}, E_{p i t}$ or $E_{b}, E_{p r o t}$ or $E_{r p}$, $i_{\max }$ and $E_{\max }$. Tafel slopes could be obtained from the polarization curves if desired. 


\section{APPENDIX B}

\section{Environmental Test Matrix}

Synthetic environments which, historically, have been used to simulate field conditions in laboratory corrosion studies are usually relatively simple. More often than not, the effects of variables are studied by varying a single variable at a time. Such an approach does not account for the dependency of effects among multiple variables. In this project, a statistical approach is used that was specifically designed to examine corrosion behavior in complex environments (Koch, et al.). By using a statistically-based experimental design, a mathematical expression is developed that relates a dependent variable or response, such as corrosion rate, to a number of independent solution variables or factors, such as species concentration, temperature, and $\mathrm{pH}$. In such an analysis, the mathematical expressions can include main-effect terms (linear), two factor interactions (cross products), and quadratic terms. High-order terms, such as three-way interactions, can also be evaluated but their physical significance is often difficult to explain and the magnitude of the terms are expected to be much smaller than the main-effect terms or twofactor interaction terms. Because of the large number of solution variables (15), and the large number of alloys (4) being examined in this study, it was decided that the most effective approach was to determine the main-effect terms for each of the variables free and clear of two-factor interactions but not to perform the much larger matrix of experiments required to begin to determine the two-factor interactions and quadratic terms. To estimate the main-effect terms of the variables, a Resolution IV experimental design was selected. In this design, each environmental variable has a high and low level. Thirty-two high-low combinations are required to determine the main-effect terms for fifteen variables.

The initial step was to define the solution variables of interest for inclusion into the test matrix. Table B.1 presents the compositional ranges of important environmental species for (1) Tuff well water, (2) Tuff groundwater heated to temperatures from $90-250^{\circ} \mathrm{C}$ in the presence of Tuff rock, and (3) Tuff groundwater heated to $90-150^{\circ} \mathrm{C}$ in the presence of radiation. The references from which the data were obtained are indicated in Table B.1.

The fifteen environmental variables that were included in the experimental matrix and their high and low concentrations are given in Table B.2. The fifteen variables selected for examination in the Task 3 tests included twelve variables associated with the J-13 groundwater and three variables produced by radiolysis. Nitrogen, sulfate, and sodium were chosen as the gas, anion and cation, respectively, used for balancing the solution chemistry. One variable that is missing from the fifteen environmental variables listed in Table B.2 is the radiolysis product hydrogen. Because of the experimental difficulties in mixing hydrogen and oxygen, it was decided to remove hydrogen from the matrix of experiments and to perform a few experiments separately to establish its effect. A complete summary of the solution matrix investigated during the entire 3.5 year program is outlined in Table B.3.

In the following paragraphs, each variable is briefly discussed and justification for inclusion of the variable into the matrix and the concentrations selected are presented based on a review of the literature (Knauss-1985a, Glass-1986, Oversby-1983, Yunker-1986a, et al.). 
Table B.1 Concentration Ranges For Environmental Species In Tuff Groundwater.

\begin{tabular}{|c|c|c|c|c|c|}
\hline $\begin{array}{c}\text { Environmental } \\
\text { Variable }\end{array}$ & $\begin{array}{c}\text { Nominal } \\
\text { Concentration of } \\
\text { Well Water, } \\
\text { mg/ }\end{array}$ & $\begin{array}{r}\text { Concentrat } \\
\text { Of Groundw } \\
\text { To } 90-250^{\circ} \\
\text { Rock, }\end{array}$ & $\begin{array}{l}\text { tion Range } \\
\text { vater Heated } \\
\text { "C With Tuff } \\
\text { (ab) mgl }\end{array}$ & $\begin{array}{l}\text { Concentrat } \\
\text { Of Groundw } \\
\text { To } 90-150^{\circ} \mathrm{C} \\
\text { Of Radiati }\end{array}$ & $\begin{array}{l}\text { lion Range } \\
\text { ater Heated } \\
\text { In Presence } \\
\text { ion }^{(\theta)}, \mathrm{mg} /\end{array}$ \\
\hline $\mathrm{pH}$ & 7.6 & 5.8 & -8.3 & 7.6 & -9.0 \\
\hline $\mathrm{SiO}_{2}$ & 58 & 29 & -394 & 1.05 & - 3.10 \\
\hline $\mathrm{HCO}_{3}^{-}$ & 125 & 45 & -195 & 8.1 & -21 \\
\hline $\mathbf{F}$ & 2.2 & 2.2 & - 4.4 & 0.38 & - 1.4 \\
\hline $\mathrm{Cl}$ & 6.9 & 6.5 & - 8.9 & 2.5 & - $\quad 5.8$ \\
\hline $\mathrm{NO}_{3}^{-}$ & 9.6 & 8.5 & -16.8 & 2.5 & -18.8 \\
\hline $\mathrm{SO}_{4}^{2-}$ & 18.7 & 13.3 & -22 & 1.8 & - 6.2 \\
\hline $\mathrm{NO}_{2}^{-}$ & - & 0.7 & - 1.5 & 1.2 & $-\quad 3.8$ \\
\hline $\mathrm{H}_{2} \mathrm{O}_{2}$ & - & & - & 0 & $=4.8^{(0)}$ \\
\hline $\mathrm{Al}^{3+}$ & .012 & 0.016 & - 4.8 & $<0.15$ & - $\quad 0.18$ \\
\hline $\mathrm{Fe}^{2+}$ & 0.006 & & - & $<0.02$ & -0.04 \\
\hline $\mathrm{Ca}^{2+}$ & 12.5 & 0.21 & - 13.2 & 2.7 & - 9.8 \\
\hline $\mathrm{Mg}^{2+}$ & 1.9 & 0.009 & -2.0 & 0.6 & - 1.1 \\
\hline $\mathrm{K}^{+}$ & 5.1 & 3.2 & -19.4 & 2.4 & -4.8 \\
\hline $\mathrm{Na}^{+}$ & 44 & 35 & -74 & 2.8 & -36 \\
\hline
\end{tabular}

(a) Knauss, 1985.

(b) Oversby, 1983.

(c) Yunker, 1986.

(d) Glass, 1985. 
Table B.2 List Of Variables Included In The Matrix Of Potentiodynamic Polarization Tests In Task 2 (Beavers - 1989).

\begin{tabular}{|c|c|c|c|c|c|}
\hline $\begin{array}{l}\text { Variable } \\
\text { Number }\end{array}$ & $\begin{array}{l}\text { Variable } \\
\text { Name }\end{array}$ & Origin & $\begin{array}{c}\text { Test Matrix } \\
\text { High Concentration } \\
\text { mgl }\end{array}$ & $\begin{array}{c}\text { Test Matrix } \\
\text { Low Concentration } \\
\text { mgl }\end{array}$ & $\begin{array}{c}\text { Nominal } \\
\text { Concentration } \\
\text { Of J-13, mg/ }\end{array}$ \\
\hline 1 & $\mathrm{SiO}_{2}$ & $J-13$ & 215 & 2.2 & 58 \\
\hline 2 & $\mathrm{HCO}_{3}^{-}$ & $J-13$ & 2000 & 0.4 & 125 \\
\hline 3 & $F$ & $J-13$ & 200 & 0.04 & 2.2 \\
\hline 4 & $\mathrm{Cl}^{\circ}$ & $J-13$ & 1000 & 0.2 & 6.9 \\
\hline 5 & $\mathrm{NO}_{3}^{-}$ & $J-13$ & 1000 & 0.2 & 9.6 \\
\hline 6 & $\mathrm{NO}_{2}^{-}$ & Radiolysis & 200 & 0 & - \\
\hline 7 & $\mathrm{H}_{2} \mathrm{O}_{2}$ & Radiolysis & 200 & 0 & - \\
\hline 8 & $\mathrm{Ca}^{2+}$ & $J-13$ & 0.8 & 0.004 & 12 \\
\hline 9 & $\mathrm{Mg}^{2+}$ & $J-13$ & 0.8 & 0.004 & 1.9 \\
\hline 10 & $\left.A\right|^{3+}$ & $J-13$ & 0.8 & 0.0004 & 0.01 \\
\hline 11 & $\mathrm{PO}_{4}^{3 \cdot}$ & $J-13$ & 2.0 & 0.01 & $0.12^{*}$ \\
\hline 12 & Oxalic Acid & Radiolysis & 172 & 0 & - \\
\hline 13 & $\mathrm{O}_{2}$ & $\begin{array}{c}\text { Open Repository } \\
\text { and Radiolysis }\end{array}$ & $30^{* *}$ & $5^{\star \star *}$ & - \\
\hline 14 & Temp & $J-13$ & $90^{\circ} \mathrm{C}$ & $50^{\circ} \mathrm{C}$ & - \\
\hline 15 & $\mathrm{pH}$ & $J-13$ & 10 & 5 & 7.6 \\
\hline
\end{tabular}

* McCright, R. D. FY 1985 Status Report, UCID-20509, September 30, 1985.

** Volume \%. 
Table B.3 Series Of Tests Included In The Matrix Of Potentiodynamic Polarization Tests in Task 2 (Beavers-1989).

\begin{tabular}{|c|c|c|c|c|c|c|c|c|c|c|c|c|c|c|c|}
\hline $\begin{array}{l}\text { Test } \\
\text { No. }\end{array}$ & $\mathrm{SiO}_{2}$ & $\mathrm{HCO}_{3}^{-}$ & $F$ & $\mathrm{Cl}^{-}$ & $\mathrm{NO}_{3}^{\circ}$ & $\mathrm{NO}_{2}^{-}$ & $\mathrm{H}_{2} \mathrm{O}_{2}$ & $\mathrm{Ca}^{2+}$ & $\mathrm{Mg}^{2+}$ & $\mathrm{A}^{3+}$ & $\mathrm{PO}_{4}^{3+}$ & $\begin{array}{l}\text { Oxalic } \\
\text { Acid }\end{array}$ & $\mathrm{O}_{2}$ & $\begin{array}{l}\text { Temp } \\
{ }^{\circ} \mathrm{C}\end{array}$ & $\mathrm{pH}$ \\
\hline 1 & 2.2 & 0.4 & 200 & 1000 & 1000 & 200 & 200 & 0.8 & 0.004 & 0.0004 & 0.01 & 0 & 5 & 90 & 5 \\
\hline 2 & 2.2 & 2000 & 200 & 1000 & 1000 & 0 & 0 & 0.004 & 0.004 & 0.8 & 2.0 & 172 & 5 & 50 & 5 \\
\hline 3 & 215 & 0.4 & 0.04 & 0.2 & 1000 & 200 & 0 & 0.8 & 0.004 & 0.8 & 2.0 & 0 & 30 & 50 & 5 \\
\hline 4 & 215 & 2000 & 0.04 & 0.2 & 1000 & 0 & 200 & 0.004 & 0.004 & 0.0004 & 0.01 & 172 & 30 & 90 & 5 \\
\hline 5 & 2.2 & 0.4 & 200 & 0.2 & 0.2 & 0 & 200 & 0.8 & 0.8 & 0.8 & 0.01 & 172 & 30 & 50 & 5 \\
\hline 6 & 2.2 & 2000 & 200 & 0.2 & 0.2 & 200 & 0 & 0.004 & 0.8 & 0.0004 & 2.0 & 0 & 30 & 90 & 5 \\
\hline 7 & 215 & 0.4 & 0.04 & 1000 & 0.2 & 0 & 0 & 0.8 & 0.8 & 0.0004 & 2.0 & 172 & 5 & 90 & 5 \\
\hline 8 & 215 & 2000 & 0.04 & 1000 & 0.2 & 200 & 200 & 0.004 & 0.8 & 0.8 & 0.01 & 0 & 5 & 50 & 5 \\
\hline 9 & 2.2 & 0.4 & 0.04 & 1000 & 0.2 & 200 & 200 & 0.004 & 0.004 & 0.0004 & 2.0 & 172 & 30 & 50 & 10 \\
\hline 10 & 2.2 & 2000 & 0.04 & 1000 & 0.2 & 0 & 0 & 0.8 & 0.004 & 0.8 & 0.01 & 0 & 30 & 90 & 10 \\
\hline 11 & 215 & 0.4 & 200 & 0.2 & 0.2 & 200 & 0 & 0.004 & 0.004 & 0.8 & 0.01 & 172 & 5 & 90 & 10 \\
\hline 12 & 215 & 2000 & 200 & 0.2 & 0.2 & 0 & 200 & 0.8 & 0.004 & 0.0004 & 2.0 & 0 & 5 & 50 & 10 \\
\hline 13 & 2.2 & 0.4 & 0.04 & 0.2 & 1000 & 0 & 200 & 0.004 & 0.8 & 0.8 & 2.0 & 0 & 5 & 90 & 10 \\
\hline 14 & 2.2 & 2000 & 0.04 & 0.2 & 1000 & 200 & 0 & 0.8 & 0.8 & 0.0004 & 0.01 & 172 & 5 & 50 & 10 \\
\hline 15 & 215 & 0.4 & 200 & 1000 & 1000 & 0 & 0 & 0.004 & 0.8 & 0.0004 & 0.01 & 0 & 30 & 50 & 10 \\
\hline 16 & 215 & 2000 & 200 & 1000 & 1000 & 200 & 200 & 0.8 & 0.8 & 0.8 & 2.0 & 172 & 30 & 90 & 10 \\
\hline 17 & 215 & 2000 & 0.04 & 0.2 & 0.2 & 0 & 0 & 0.004 & 0.8 & 0.8 & 2.0 & 172 & 30 & 50 & 10 \\
\hline 18 & 215 & 0.4 & 0.04 & 0.2 & 0.2 & 200 & 200 & 0.8 & 0.8 & 0.0004 & 0.01 & 0 & 30 & 90 & 10 \\
\hline 19 & 2.2 & 2000 & 200 & 1000 & 0.2 & 0 & 200 & 0.004 & 0.8 & 0.0004 & 0.01 & 172 & 5 & 90 & 10 \\
\hline 20 & 2.2 & 0.4 & 200 & 1000 & 0.2 & 200 & 0 & 0.8 & 0.8 & 0.8 & 2.0 & 0 & 5 & 50 & 10 \\
\hline 21 & 215 & 2000 & 0.04 & 1000 & 1000 & 200 & 0 & 0.004 & 0.004 & 0.0004 & 2.0 & 0 & 5 & 90 & 10 \\
\hline 22 & 215 & 0.4 & 0.04 & 1000 & 1000 & 0 & 200 & 0.8 & 0.004 & 0.8 & 0.01 & 172 & 5 & 50 & 10 \\
\hline 23 & 2.2 & 2000 & 200 & 0.2 & 1000 & 200 & 200 & 0.004 & 0.004 & 0.8 & 0.01 & 0 & 30 & 50 & 10 \\
\hline 24 & 2.2 & 0.4 & 200 & 0.2 & 1000 & 0 & 0 & 0.8 & 0.004 & 0.0004 & 2.0 & 172 & 30 & 90 & 10 \\
\hline 25 & 215 & 2000 & 200 & 0.2 & 1000 & 0 & 0 & 0.8 & 0.8 & 0.8 & 0.01 & 0 & 5 & 90 & 5 \\
\hline 26 & 2.2 & 0.4 & 200 & 0.2 & 1000 & 200 & 200 & 0.004 & 0.8 & 0.0004 & 2.0 & 172 & 5 & 50 & 5 \\
\hline 27 & 2.2 & 2000 & 0.04 & 1000 & 1000 & 0 & 200 & 0.8 & 0.8 & 0.0004 & 2.0 & 0 & 30 & 50 & 5 \\
\hline 28 & 2.2 & 0.4 & 0.04 & 1000 & 1000 & 200 & 0 & 0.004 & 0.8 & 0.8 & 0.01 & 172 & 30 & 90 & 5 \\
\hline 29 & 215 & 2000 & 200 & 1000 & 0.2 & 200 & 0 & 0.8 & 0.004 & 0.0004 & 0.01 & 172 & 30 & 50 & 5 \\
\hline 30 & 215 & 0.4 & 200 & 1000 & 0.2 & 0 & 200 & 0.004 & 0.004 & 0.8 & 2.0 & 0 & 30 & 90 & 5 \\
\hline 31 & 2.2 & 2000 & 0.04 & 0.2 & 0.2 & 200 & 200 & 0.8 & 0.004 & 0.8 & 2.0 & 172 & 5 & 90 & 5 \\
\hline 32 & 2.2 & 0.4 & 0.04 & 0.2 & 0.2 & 0 & 0 & 0.004 & 0.8 & 0.0004 & 0.01 & 0 & 5 & 50 & 5 \\
\hline $33^{*}$ & 108 & 500 & 50 & 250 & 250 & 50 & 50 & 0.2 & 0.2 & 0.2 & 1.3 & 43 & 15 & 70 & 7.5 \\
\hline $34^{*}$ & 108 & 500 & 50 & 250 & 250 & 50 & 50 & 0.2 & 0.2 & 0.2 & 1.3 & 43 & 15 & 70 & 7.5 \\
\hline $35^{*}$ & 108 & 500 & 50 & 250 & 250 & 50 & 50 & 0.2 & 0.2 & 0.2 & 1.3 & 43 & 15 & 70 & 7.5 \\
\hline $36^{*}$ & 108 & 500 & 50 & 250 & 250 & 50 & 50 & 0.2 & 0.2 & 0.2 & 1.3 & 43 & 15 & 70 & 7.5 \\
\hline
\end{tabular}

- Tests 33 through 36 are quadruplicate midpoint tests which help to establish the degree of reproducibility of the CPP Tests. 
Silicon dioxide, $\mathrm{SiO}_{2}$, is present in the $\mathrm{J}-13$ well water at a concentration of $58 \mathrm{mg} / \mathrm{l}$. Data by Knauss-1985a and Oversby- 1983 indicate that, at $90^{\circ} \mathrm{C}$, this is the approximate steady-state concentration which likely represents the solubility limit of $\mathrm{SiO}_{2}$ at $90^{\circ} \mathrm{C}$. During radiation, Yunker$1986 \mathrm{a}$ found that the concentration of $\mathrm{SiO}_{2}$ decreased to a value of 1.1 to $3.2 \mathrm{mg} / \mathrm{l}$. Because of this, a low concentration of $2.2 \mathrm{mg} / \mathrm{l}$ was selected. A high concentration of $215 \mathrm{mg} / \mathrm{l}$ provides a factor of $100 \mathrm{X}$ between the low and high concentration examined. Also, the $100 \mathrm{mg} / \mathrm{l}$ concentration is likely to exceed the solubility limit such that the high concentration primarily insures that saturation is attained during the high concentration tests. Silicon dioxide was added to the test solutions as silicic acid.

Bicarbonate, $\mathrm{HCO}_{3}{ }^{-}$, is present in the $\mathrm{J}-13$ well water at a concentration of $125 \mathrm{mg} / \mathrm{l}$. Heating the $\mathrm{J}-13$ well water in the presence of Tuff rock at $90^{\circ} \mathrm{C}$ produced an increase in the concentration to $190 \mathrm{mg} / \mathrm{l}$ while radiation tended to decrease the concentration to $8-20 \mathrm{mg} / \mathrm{l}$. Therefore, a low concentration of $0.4 \mathrm{mg} / \mathrm{l}$ was selected and a factor of $5000 \mathrm{X}$ was used to provide a high concentration of $2000 \mathrm{mg} / \mathrm{l}$. Bicarbonate was added to the test solutions as sodium bicarbonate.

Fluoride, $\mathrm{F}^{*}$, is present in the $\mathrm{J}-13$ well water at a concentration of $2.2 \mathrm{mg} / \mathrm{l}$. Heating in the presence of Tuff rock resulted in a very slight increase in fluoride concentration. Radiation produced a slight decrease in fluoride concentration to $0.4-1.4 \mathrm{mg} / \mathrm{l}$. Based on these results, a $0.04 \mathrm{mg} / \mathrm{l}$ low concentration was selected and a factor of $500 \mathrm{X}$ provides a high concentration of $200 \mathrm{mg} /$. Fluoride was added to the test solutions as potassium fluoride.

Chloride, $\mathrm{Cl}^{-}$, is present in the $\mathrm{J}-13$ well water at a concentration of $7 \mathrm{mg} /$. Heating of the $\mathrm{J}-13$ well water in the presence of Tuff rock produced little or no change in the chloride concentration. The effect of radiation was to produce a slight decrease in the chloride concentration to 2.5-5.8 $\mathrm{mg} / \mathrm{l}$. The low concentration was selected at $0.2 \mathrm{mg} / \mathrm{l}$ and a factor of $5000 \mathrm{X}$ increase provides a high concentration of $1000 \mathrm{mg} /$. Chloride was added to the test solution as sodium chloride.

Nitrate, $\mathrm{NO}_{3}^{-}$, is present in the $\mathrm{J}-13$ well water at a concentration of $10 \mathrm{mg} /$. Very little change was observed in the nitrate concentration upon heating in the presence of Tuff rock. In the presence of radiation, the nitrate concentration varied from 2.5 to $19 \mathrm{mg} / \mathrm{l}$. Thereby, no systematic increase or decrease in the nitrate concentration was observed. The low concentration for nitrate was selected at $0.2 \mathrm{mg} /$ and a factor of $200 \mathrm{X}$ provides a high concentration of $1000 \mathrm{mg} / \mathrm{l}$. Nitrate was added to the test solutions as sodium nitrate.

Nitrite, $\mathrm{NO}_{2}^{-}$, is a radiolysis product which has been shown to achieve concentrations from 0.7 to $3.8 \mathrm{mg} / \mathrm{l}$. The low concentration for nitrite is zero. A high concentration of $200 \mathrm{mg} / \mathrm{l}$ was selected and is approximately 50X the concentration indicated by Yunker (1986a). Nitrite was added to the test solutions as sodium nitrite.

Peroxide, $\mathrm{H}_{2} \mathrm{O}_{2}$, is a radiolysis product and was shown to achieve a concentration of $5 \mathrm{mg} / \mathrm{h}$ the presence of radiation. The low concentration was selected as zero and a high concentration was selected at $200 \mathrm{mg} / \mathrm{l}$ which provides a factor of approximately $40 \mathrm{X}$ over the concentration indicated by Glass (1986).

Calcium, $\mathrm{Ca}^{2+}$, is present in the $\mathrm{J}-13$ well water at a concentration of $12 \mathrm{mg} / \mathrm{l}$. The concentration of calcium changed little when the $\mathrm{J}-13$ well water was heated in the presence of Tuff rock at $90^{\circ} \mathrm{C}$. At higher temperatures, the calcium concentration decreased to $0.2 \mathrm{mg} / \mathrm{l}$. In the presence 
of radiation, the concentration of calcium decreased to $2-9.8 \mathrm{mg} /$. The low concentration for calcium was selected at $0.004 \mathrm{mg} / \mathrm{l}$ and a factor of $200 \mathrm{X}$ provides a high concentration of 0.8 $\mathrm{mg} /$. Calcium was added to the test solutions as calcium sulfate, one-half hydrate.

Magnesium, $\mathrm{Mg}^{2+}$, is present in the $\mathrm{J}-13$ well water at a concentration of $1.9 \mathrm{mg} / \mathrm{l}$. The concentration of magnesium changed little when the $\mathrm{J}-13$ well water was heated in the presence of Tuff rock and showed only a slight decrease in concentration in the presence of radiation. The low concentration for magnesium was selected at $0.004 \mathrm{mg} /$ and a factor of $200 \mathrm{X}$ provides a high concentration of $0.8 \mathrm{mg} / \mathrm{l}$. Magnesium was added to the test solutions as magnesium sulfate, seven hydrate.

Aluminum, $\mathrm{Al}^{3+}$, is present in the $\mathrm{J}-13$ well water at a concentration of $0.01 \mathrm{mg} /$. Upon heating the $\mathrm{J}-13$ well water in the presence of Tuff rock, the aluminum concentration increased to $2-3$ $\mathrm{mg} / \mathrm{l}$. In the presence of radiation, the aluminum increased to $0.18 \mathrm{mg} / \mathrm{l}$. Therefore, a much larger range of concentration was observed for aluminum than was observed for other species. Thereby, a low concentration of 0.0004 was selected and a factor of $2000 \mathrm{X}$ provides a high concentration of $0.8 \mathrm{mg} / \mathrm{l}$. Aluminum was added to the test solutions as aluminum sulfate, 16 hydrate.

Phosphate, $\mathrm{PO}_{4}{ }^{3 \cdot}$, has been reported at a concentration of $0.12 \mathrm{mg} / \mathrm{in} \mathrm{J-13}$ well water (McCright1985) and has not been reported, at all, in other referenced $\mathrm{J}-13$ well waters. The low concentration for phosphate was selected to be $0.01 \mathrm{mg} / \mathrm{l}$ and a factor of 200X provides a high concentration of $2.0 \mathrm{mg} /$. Phosphate was added to the test solutions as phosphoric acid.

Organic acids have been reported as naturally occurring in groundwaters and have been indicated as possible radiolysis products. For this study, oxalic acid was selected as the organic acid to examine. The low concentration of oxalic acid will be zero and the high concentration for oxalic acid will be $172 \mathrm{mg} / \mathrm{l}$ which approximates to the concentration range of other radiolysis products.

Oxygen, $\mathrm{O}_{2}$, is present in the repository because of its location above the water table and because no airtight sealing arrangement is proposed for the repository. It is likely that the concentration of $\mathrm{O}_{2}$ could be somewhat less than that normally occurring in air and, on the high side, could be greater than that occurring in air due to radiolysis. The low concentration of $\mathrm{O}_{2}$ was selected at 5 volume percent and the high concentration at 30 volume percent.

Because the repository design will not permit any significant pressure buildup, the aqueous phase corrosion, which is being examined in this task, has a limiting temperature at the boiling point of the $\mathrm{J}-13$ well water. The low temperature to be examined was selected at $50^{\circ} \mathrm{C}$ and the high temperature was selected at $90^{\circ} \mathrm{C}$. The high temperature of $90^{\circ} \mathrm{C}$ was selected to provide a temperature near boiling but that can be controlled relatively easily and accurately in the laboratory.

The $\mathrm{pH}$ of the $\mathrm{J}-13$ well water is slightly alkaline, having been reported at $\mathrm{pH}$ 7.6. Upon heating of the $\mathrm{J}-13$ well water in the presence of Tuff rock, the $\mathrm{pH}$ varied only slightly when heated at $90^{\circ} \mathrm{C}$ and decreased down to 6.0 when heated at $250^{\circ} \mathrm{C}$. In the presence of radiation, the $\mathrm{pH}$ has been observed to increase to 9.0. To provide a somewhat larger range of $\mathrm{pH}$ for the test matrix, the low $\mathrm{pH}$ was selected at 5 and the high $\mathrm{pH}$ was selected at 10. 
For balancing the solution chemistry, sodium and sulfate, as well as the nitrogen concentration of the purging gas, will be permitted to vary. 
APPENDIX C

Candidate Alloy Compositions

\begin{tabular}{|c|c|c|c|c|}
\hline Element & CDA 102 & CDA 715 & 825 & $304 L$ \\
\hline $\mathrm{Cu}$ & $\geq 99.99$ & 68.55 & 1.97 & 0.33 \\
\hline $\mathrm{Ni}$ & & 30.0 & 44.83 & 8.86 \\
\hline $\mathrm{Fe}$ & & 0.548 & 26.98 & Balance \\
\hline $\mathrm{Cr}$ & & - & 21.93 & 18.18 \\
\hline Mo & & - & 2.73 & 0.24 \\
\hline $\mathrm{Mn}$ & & 0.617 & 0.45 & 1.68 \\
\hline$C$ & & 0.035 & 0.02 & 0.03 \\
\hline$S$ & & 0.007 & 0.002 & 0.018 \\
\hline $\mathrm{Zn}$ & & 0.109 & - & - \\
\hline$P$ & & 0.006 & - & 0.026 \\
\hline $\mathrm{Pb}$ & & 0.008 & - & - \\
\hline Si & & - & 0.31 & 0.54 \\
\hline Al & & - & 0.04 & - \\
\hline $\mathrm{Ti}$ & & - & 0.74 & - \\
\hline Co & & - & - & 0.15 \\
\hline$N$ & & - & - & 0.066 \\
\hline
\end{tabular}




\section{Immersion Studies On Gandidate Container Alloys For The Tuff Repository}

3.

\begin{tabular}{|c|c}
\hline \multicolumn{2}{|c|}{ DATE REPORT PUBLISHED } \\
MONTH & YEAR \\
MaY & 1991
\end{tabular}

4. FIN OR GRANT NUMBER D1692
Technical

7. PERIOD COVERED (InClusive Dares)

\section{$12 / 87-02 / 90$}

8. PERFORMING ORGANIZATION - NAME AND ADDRESS (ii NRC, provide Division, Office or Region, U.S. Nuclear kegulatony Commission, and mailing oddress; if contratior, provide neme and mailing addrest)

Cortest Columbus Technologies

2704 Sawbury Boulevard

Columbus, Ohio 43235

9. SPONSORING ORGANIZATION - NAME AND ADDRESS III NRC, sype "Same es above"; if coneractor, provide NAC Division, Office or Region, U.S. Nuclear Regulatory Commission. and malling address!
Division of Engineering
Office of Nuclear Regulatory Research
U. S. Nuclear Regulatory Commission
Washington, DC 20555

10. SUPPLEMENTARY NOTES

\section{ABSTRACT 1200 words or tessi}

Cortest Columbus Technologies (CC Technologies) is investigating the long-term performance of container materials used for high-level radioactive waste packages. This information is being developed for the Nuclear Regulatory Commission to aid in their assessment of the Department of Energy's application to construct a geologic repository for disposal of high-level radioactive waste. This report summarizes the results of exposure studies performed on two copper-base and two Fe-Cr-Ni alloys in simulated Tuff Repository conditions. Testing was performed at $90^{\circ} \mathrm{C}$ in three environments; simulated $\mathrm{J}-13$ wall water, and two environments that simulated the chemical effects resulting from boilling and irradiation of the groundwater. Creviced specimens and U-bends were exposed to liquid, to vapor above the condensed phase, and to altemate immersion. A rod specimen was used to monitor corrosion at the vapor-liquid interface. The specimens were evaluated by electrochemical, gravimetric, and metallographic techniques following approximately 2000 hours of exposure.

Results of the exposure tests indicated that all four alloys exhibited accoptable general corrosion rates in simulated $\mathrm{J}-13 \mathrm{well}$ water. These rates decreased with time. Incipient pitting was observed under deposits on Alloy 825 and pitting was observed on both Alloy CDA 102 and Alloy CDA 715 in the simulated $\mathrm{J}-13$ well water. No SCC was observed in U-bend specimens of any of the alloys in simulated J-13 well water.

General corrosion rates of the copper-base alloys in àn active-corrosion environment were moderate, and no SCC was observed. However, severe pitting and crevice corrosion occurred in this environment. Both Alloy $304 \mathrm{~L}$ and Alloy 825 exhibited low general corrosion rates with no evidence of localiżed corrosion (pitting, crevice corrosion or SCC) in a pitting environment in the absence of hydrogen peroxide $\left(\mathrm{H}_{2} \mathrm{O}_{2}\right)$, a species added to simulate the effects of radiolysis. Alloy 825 continued to exhibit good corrosion performance after $\mathrm{H}_{2} \mathrm{O}_{2}$ was added to the pitting environment; whiereas, Alloy $304 \mathrm{~L}$ exhibited both pitting aind SC'C as a result of the $\mathrm{H}_{2} \mathrm{O}_{2}$ addition.

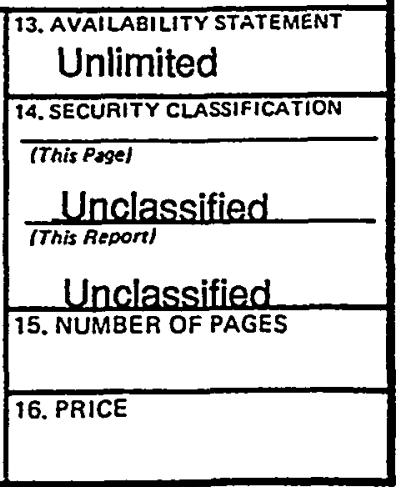

Cöpper-Base Allòys

Fe-Cr-Ni Alloys

Environmental Effects

High Level Nuclear Waste Disposal

Tuff Repository

\section{Corrosion \\ Localized Corrosion \\ Stress-Corrosion Cracking}

